DOE/GJ/79491-934

\title{
Supporting Evaluation for the Proposed Plan for Final Remedial Action for the Groundwater Operable Unit at the Chemical Plant Area of the Weldon Spring Site, Weldon Spring, Missouri
}

August 2003

prepared by

Environmental Assessment Division, Argonne National Laboratory

prepared for

U.S. Department of Energy, Weldon Spring Site Remedial Action Project,

Weldon Spring, Missouri, under Contract W-31-109-ENG-38 



\section{CONTENTS}

NOTATION

vii

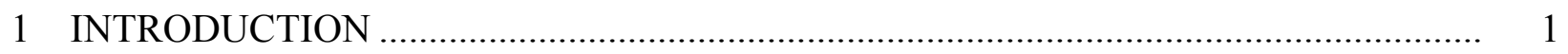

1.1 Summary of Previous Evaluations of Alternatives ..................................................... 1

1.2 Purpose and Scope of This Report ......................................................................... 3

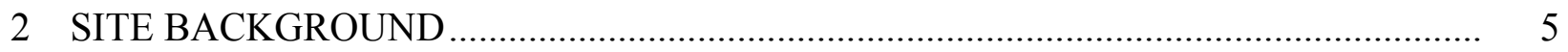

2.1 Current Groundwater and Spring Water Conditions................................................ 5

2.1.1 Groundwater ................................................................................... 5

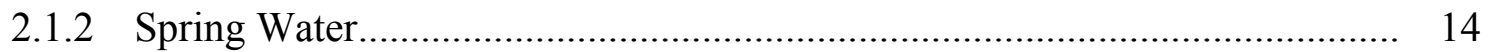

2.2 Site Setting ..................................................................................................... 14

2.2.1 Geology and Hydrogeology ......................................................................... 14

2.2.2 Surface Water .................................................................................. 17

2.2.3 Land Use........................................................................................... 17

2.2.4 Groundwater Use.......................................................................... 18

2.2.5 Summary of Risk................................................................................. 19

2.2.6 Remedial Action Objectives..................................................................... 21

3 REEVALUATION OF TECHNOLOGIES AND IDENTIFICATION

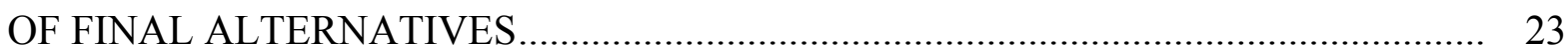

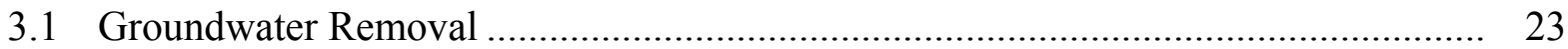

3.1.1 Description of the Field Studies ................................................................ 24

3.1.2 Results of the Field Studies ....................................................................... 29

3.1.3 Evaluation of the Groundwater Removal Technologies

for Application at the Chemical Plant Area ................................................ 30

3.1.3.1 Effectiveness ......................................................................... 30

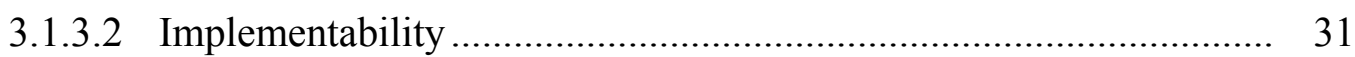

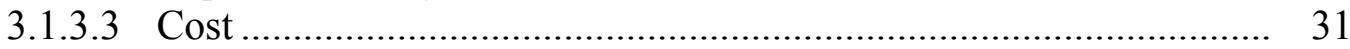

3.2 In-Situ Chemical Oxidation ................................................................................. 32

3.2.1 Description of Pilot-Phase ICO ................................................................. 33

3.2.2 Results of Pilot-Phase ICO .................................................................. 37

3.2.3 Evaluation of the ICO Technology for Application
at the Chemical Plant Area ....................................................................... 39

3.2.3.1 Effectiveness ........................................................................ 39

3.2.3.2 Implementability ................................................................... 39

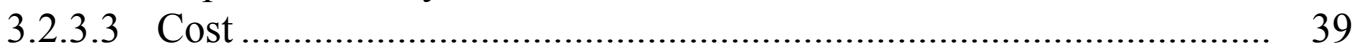

3.3 Monitored Natural Attenuation ........................................................................... 39

3.3.1 Estimates of Predicted Times for MNA .................................................... 40

3.3.2 Evaluation of MNA for Application at the Chemical Plant Area .................. 46

3.3.2.1 Effectiveness ............................................................................. 46 


\section{CONTENTS (Cont.)}

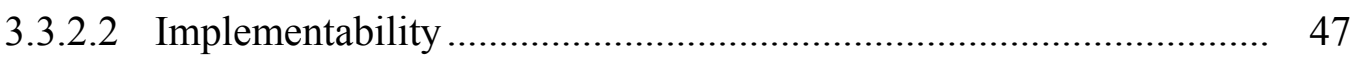

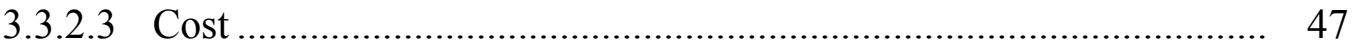

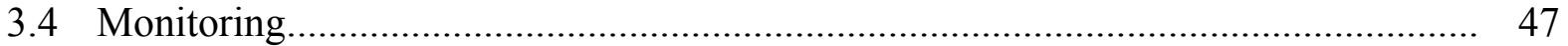

3.4.1 Description of Monitoring ............................................................................. 47

3.4.2 Evaluation of the Monitoring Technology for Application

at the Chemical Plant Area ....................................................................... 48

3.4.2.1 Effectiveness .................................................................... 48

3.4.2.2 Implementability ................................................................ 48

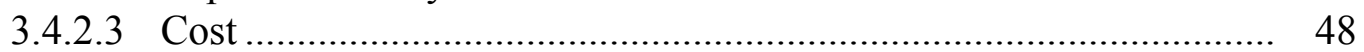

3.5 Institutional Controls................................................................................... 48

3.5.1 Description of ICs ................................................................................. 48

3.5.2 Evaluation of ICs for Application at the Chemical Plant Area ..................... 49

3.5.2.1 Effectiveness ........................................................................ 49

3.5.2.2 Implementability ................................................................... 49

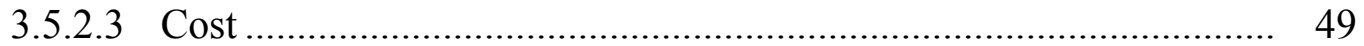

3.6 Identification of Alternatives ............................................................................... 49

4 ANALYSIS OF FINAL ALTERNATIVES ............................................................... 51

4.1 Alternative 1: No Further Action ..................................................................... 53

4.1.1 Description ..................................................................................... 53

4.1.2 Evaluation of Alternative 1 Measured against Nine Criteria ......................... 53

4.2 Alternative 2: Long-Term Monitoring with Institutional Controls ............................. 53

4.2.1 Description ................................................................................... 53

4.2.2 Evaluation of Alternative 2 Measured against Nine Criteria ........................ 56

4.3 Alternative 3: Monitored Natural Attenuation with Institutional Controls................ 57

4.3.1 Description ..................................................................................... 57

4.3.2 Evaluation of Alternative 3 Measured against Nine Criteria ........................ 58

4.4 Comparative Analysis of the Final Alternatives ………………………………........ 58

5 PRELIMINARY DESIGN FOR THE PREFERRED ALTERNATIVE.............................. 63

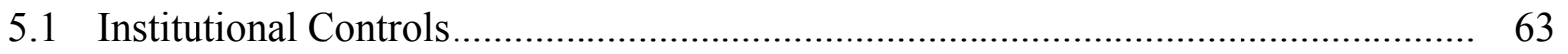

5.2 Proposed Performance Monitoring Strategy …………………………................... 65

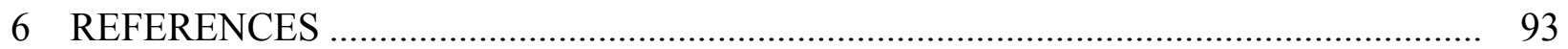




\section{FIGURES}

2.1 Locations of Monitoring Wells at the Chemical Plant Area ……................................... 6

2.2 TCE Contamination Contour Based on Average Concentrations in 2002 at the Chemical Plant Area............................................................................ 7

2.3 Nitrate Contamination Contour Based on Average Concentrations in 2002 at the Chemical Plant Area

2.4 Uranium Contamination Contour Based on Average Concentrations in 2002 at the Chemical Plant Area

2.5 2,4-DNT Contamination Contour Based on Average Concentrations in 2002 at the Chemical Plant Area ........................................................................... 10

2.6 2,6-DNT Contamination Contour Based on Average Concentrations in 2002 at the Chemical Plant Area....

2.7 2,4,6-TNT Contamination Contour Based on Average Concentrations in 2002 at the Chemical Plant Area

2.8 Locations of Springs and Drainage Areas in the Chemical Plant Area........................ 16

3.1 Locations of Wells for the Additional Field Studies ................................................... 25

3.2 Locations of Wells for Pilot-Phase In-Situ Chemical Oxidation ................................. 34

5.1 Locations of Institutional Controls at the Chemical Plant Area ................................... 64

\section{TABLES}

3.1 Events during Each Stage of the 2001 Field Studies.................................................. 27

3.2 Contaminant Masses Removed .......................................................................... 28

3.3 Representative Cost Estimates for Groundwater Removal ........................................ 32

3.4 TCE Concentrations for Pilot-Phase In-Situ Chemical Oxidation ............................... 36

3.5 Chromium Concentrations for Pilot-Phase In-Situ Chemical Oxidation ...................... 37 


\section{TABLES (Cont.)}

3.6 Revised Predictive Monitored Natural Attenuation Cleanup Times

Based on the Flushing Model ..................................................................................... 42

4.1 Nine Criteria for Evaluation of Alternatives …................................................. 52

4.2 Summary Cost Estimate for the Final Alternatives …............................................. 54

4.3 Comparative Analysis of the Final Alternatives ……………….................................. 59

5.1 Preliminary Monitored Natural Attenuation Performance Monitoring for TCE........... 67

5.2 Preliminary Monitored Natural Attenuation Performance Monitoring for Nitrate ........ 75

5.3 Preliminary Monitored Natural Attenuation Performance Monitoring

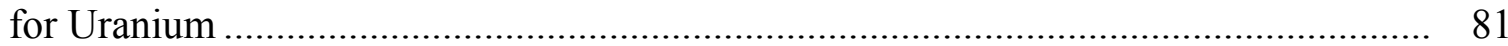

5.4 Preliminary Monitored Natural Attenuation Performance Monitoring for Nitroaromatic Compounds............................................................................... 84 


\section{NOTATION}

The following is a list of the acronyms, initialisms, and abbreviations (including units of measure) used in this document.

\section{ACRONYMS, INITIALISMS, AND ABBREVIATIONS}

\section{General}

$\begin{array}{ll}\text { ARAR } & \text { applicable or relevant and appropriate requirement } \\ \text { BRA } & \text { baseline risk assessment } \\ \text { CERCLA } & \text { Comprehensive Environmental Response, Compensation, and Liability Act } \\ \text { COC } & \text { contaminant of concern } \\ \text { DA } & \text { U.S. Department of the Army } \\ \text { DHSS } & \text { Missouri Department of Health and Senior Services } \\ \text { DOE } & \text { U.S. Department of Energy } \\ \text { EPA } & \text { U.S. Environmental Protection Agency } \\ \text { FHHS } & \text { Francis Howell High School } \\ \text { FS } & \text { feasibility study } \\ \text { GAC } & \text { granular activated carbon } \\ \text { GWOU } & \text { groundwater operable unit } \\ \text { HDPE } & \text { high-density polyethylene } \\ \text { IC } & \text { institutional control } \\ \text { ICO } & \text { in-situ chemical oxidation } \\ \text { IROD } & \text { interim record of decision } \\ \text { LTS\&M } & \text { long-term surveillance and maintenance } \\ \text { MCL } & \text { maximum contaminant level } \\ \text { MDC } & \text { Missouri Department of Conservation } \\ \text { MDNR } & \text { Missouri Department of Natural Resources } \\ \text { MDOH } & \text { Missouri Department of Health } \\ \text { MNA } & \text { monitored natural attenuation } \\ \text { MOA } & \text { memorandum of agreement } \\ \text { MoDOT } & \text { Missouri Department of Transportation } \\ \text { NCP } & \text { National Oil and Hazardous Substances Pollution Contingency Plan } \\ \text { O\&M } & \text { operation and maintenance } \\ \text { ORP } & \text { oxidation reduction potential } \\ \text { P\&T } & \text { pump and treat } \\ \text { PP } & \text { proposed plan } \\ \text { RA } & \text { remedial action } \\ \text { RAO } & \text { remedial action objective } \\ \text { RBC } & \text { risk-based concentration } \\ \text { RD } & \text { remedial design } \\ \text { RI } & \text { remedial investigation } \\ \text { ROD } & \text { Record of Decision } \\ & \end{array}$




\section{Chemicals}

1,2-DCE 1,2-dichloroethylene

1,3-DNB 1,3-dinitrobenzene

DNT dinitrotoluene

2,4-DNT 2,4-dinitrotoluene

2,6-DNT 2,6-dinitrotoluene

NB nitrobenzene

TCE trichloroethylene

1,3,5-TNB 1,3,5-trinitrobenzene

TNT trinitrotoluene

2,4,6-TNT 2,4,6-trinitrotoluene

\section{Units of Measure}

$\begin{array}{ll}\text { acre-ft } & \text { acre-foot (feet) } \\ \mathrm{cm} & \text { centimeter(s) } \\ \mathrm{d} & \text { day(s) } \\ \mathrm{ft} & \text { foot (feet) } \\ \mathrm{g} & \text { gram(s) } \\ \text { gal } & \text { gallon(s) } \\ \mathrm{gpm} & \text { gallon(s) per minute } \\ \mathrm{h} & \text { hour(s) } \\ \mathrm{ha} & \text { hectare(s) } \\ \mathrm{in} . & \text { inch(es) } \\ \mathrm{kg} & \text { kilogram(s) } \\ \mathrm{km} & \text { kilometer(s) } \\ \mathrm{L} & \text { liter(s) } \\ \mathrm{m} & \text { meter(s) } \\ \mathrm{mg} & \text { milligram(s) } \\ \mathrm{mi} & \text { mile(s) } \\ \mathrm{min} & \text { minute(s) } \\ \mathrm{pCi} & \text { picocurie(s) } \\ \mathrm{s} & \text { second(s) } \\ \mathrm{yr} & \text { year(s) } \\ \mu \mathrm{g} & \text { microgram(s) }\end{array}$




\section{SUPPORTING EVALUATION FOR THE PROPOSED PLAN FOR FINAL REMEDIAL ACTION FOR THE GROUNDWATER OPERABLE UNIT AT THE CHEMICAL PLANT AREA OF THE WELDON SPRING SITE, WELDON SPRING, MISSOURI}

\section{INTRODUCTION}

This report presents the technical information developed since the interim record of decision (IROD) was issued in September 2000 (U.S. Department of Energy [DOE] 2000). The information was incorporated into the evaluation that was performed in selecting the preferred alternative for the Chemical Plant groundwater operable unit (GWOU) of the Weldon Spring site. The contaminants of concern (COCs) in groundwater and springs are trichloroethylene (TCE), nitrate, uranium, and nitroaromatic compounds. The preferred alternative of monitored natural attenuation (MNA) coupled with institutional controls (ICs) and contingency activities is described in the Proposed Plan (PP) for Final Remedial Action for the Groundwater Operable Unit at the Chemical Plant Area of the Weldon Spring Site, Weldon Spring, Missouri (DOE 2003b).

\subsection{SUMMARY OF PREVIOUS EVALUATIONS OF ALTERNATIVES}

The Feasibility Study (FS) for the GWOU that was completed in 1998 (DOE and U.S. Department of the Army [DA] 1998) included a thorough screening of the technologies that could address groundwater COCs at the Chemical Plant area. The following categories of technologies and remedial options were evaluated in the FS: (1) monitoring, (2) ICs, (3) natural processes, (4) in-situ containment, (5) in-situ treatment, (6) groundwater removal, (7) ex-situ treatment, and (8) disposal (primarily of solid waste generated during the implementation of other technologies). Selected technologies within each category except in-situ containment were retained for consideration when the preliminary alternatives that were presented in the FS were being identified. The preliminary alternatives listed in the FS were as follows:

- Alternative 1: No Action,

- Alternative 2: Long-Term Monitoring,

- Alternative 3: MNA,

- Alternative 4: Groundwater Removal and On-Site Treatment Using Granular Activated Carbon (GAC) and Ion Exchange,

- Alternative 5: Groundwater Removal and On-Site Treatment Using Ultraviolet Oxidation, 
- Alternative 6: Groundwater Removal and On-Site Treatment Using Phytoremediation,

- Alternative 7: Removal and On-Site Treatment of Groundwater in the Vicinity of the Raffinate Pits,

- Alternative 8: In-Situ Treatment of TCE Using In-Well Vapor Stripping, and

- Alternative 9: In-Situ Chemical Oxidation (ICO) of TCE Using Fenton-Like Reagents.

These alternatives encompass a wide range of remediation options. Alternatives 2, 3, 4, 5, and 6 were developed and evaluated to determine their feasibility in addressing all contaminants in the affected aquifer, and Alternatives 7, 8, and 9 were evaluated to determine their feasibility in addressing TCE. Technologies that could address the other individual COCs were investigated, but none that merited further consideration were identified. Alternatives 1, 2, 4, 7, 8, and 9 were retained for further evaluation and analyzed in detail. Alternatives 3, 5, and 6 were not retained for further evaluation for the reasons given below.

Alternatives 5 and 6 were not evaluated in detail in the FS because the treatment technologies (ultraviolet oxidation for Alternative 5 and phytoremediation for Alternative 6) associated with these alternatives are not as established as the technology considered under Alternative 4 (GAC). Alternative 3 (MNA) was not retained because, at the time of the FS evaluations, this alternative was considered to be the same as Alternative 2 (long-term monitoring). The explanation is that the natural processes that are occurring at the site are primarily dilution and dispersion, and there is very little evidence that biological or chemical degradation is occurring. Therefore, monitoring activities performed for the MNA alternative would be similar to those performed for the long-term monitoring alternative, which primarily involves monitoring to observe decreases in contaminant concentrations over time.

The aspect of MNA that would differentiate it from long-term monitoring would be its implementation of a performance monitoring strategy. For this strategy, specific contaminant concentrations would be established at specific monitoring locations over time. Implementing this strategy would involve the ability to estimate concentration trends over time at specific locations for each of the COCs resulting from the natural processes being considered (U.S. Environmental Protection Agency [EPA] 1999; DOE 1999c). The complexity of the site hydrogeology poses challenges to developing such a performance monitoring strategy for the Chemical Plant area. The uncertainties associated with site hydrogeologic input parameters weaken the calculations for predicting the time frame in which COC concentrations could be reduced to applicable standards. However, calculations of time frames were performed and are presented in the Supplemental FS (DOE 1999a). The results indicate that it would take a long time (on the order of hundreds of years) for MNA to reduce contaminant concentrations to applicable standards. A similar calculation was performed for conventional groundwater removal using vertical wells. It was estimated that it would take an equally long time (on the order of hundreds of years, similar to the amount of time estimated for MNA) for contaminant concentrations to be reduced to applicable standards. These calculations were performed so that a 
comparison could be made between groundwater removal and MNA. Because the resultant times for MNA and groundwater removal would not be different (taking an equally long time) and because the overall MNA and long-term monitoring strategies would be similar (designed primarily for observing decreases in contaminant concentrations over time and not for monitoring degradation or breakdown products over time), it was determined that the alternative of long-term monitoring would achieve the same goal. This information was incorporated into the selection of the preferred alternative presented in the 1999 PP (DOE 1999b).

The PP issued for review in 1999 (DOE 1999b) identified a proposed action that consisted of active remediation of TCE (Alternative 9) and long-term monitoring of the other COCs (Alternative 2). On the basis of comments received from the Missouri Department of Natural Resources (MDNR) and members of the public, who expressed concern that the proposal included active treatment for TCE only and not for all COCs, DOE decided (1) to postpone the final groundwater decision until further field studies could be conducted to reexamine the effectiveness and practicality of further active remediation methods for the other COCs and (2) to move forward with the treatment of TCE. Consequently, the IROD was signed in September 2000 (DOE 2000).

\subsection{PURPOSE AND SCOPE OF THIS REPORT}

The primary purpose of this report is to reevaluate the feasibility of groundwater removal, ICO, and MNA technologies and options on the basis of recent information collected since the IROD was signed. In particular, this report provides (1) a reevaluation of the ICO process, by examining the results of the pilot-phase ICO process that was implemented in 2002 to address TCE contamination; (2) a reevaluation of the groundwater removal technology, by examining the data obtained from additional field studies that were conducted in 2001 to determine the effects of enhanced groundwater removal; and (3) revised calculations for predicting the time it takes for natural attenuation processes to reduce contaminant concentrations to federal drinking water standards (given as maximum contaminant levels [MCLs]), State of Missouri water quality standards, or risk-based concentrations (RBCs) for COCs for which no standards are available. These calculations were originally presented in the Supplemental FS (DOE 1999a).

An evaluation of the remedial options presented in this report resulted in the identification of three alternatives. They are: (1) No Further Action, (2) Long-Term Monitoring with ICs, and (3) MNA with ICs. These alternatives are evaluated in this report as final alternatives because they represent the best available options after all data (including recently obtained information) were evaluated. The field tests conducted in 1998 and 2001 (MK-Ferguson Company and Jacobs Engineering Group 1998, 2002) indicated that developing an effective groundwater removal system that would use conventional or enhanced techniques (angled wells and artificial recharge) would be difficult because of the limitations imposed by the complex site hydrogeology. The pilot-phase ICO that was implemented in 2002 for the IROD indicated that developing a design to treat the entire TCE plume to the MCL would also be limited by the same site conditions. Because of these limitations, groundwater removal and fullscale ICO were not further considered as viable alternatives for evaluation. The revised calculations for MNA indicated that the time frames for achieving applicable standards would be 
shorter than previously determined and are considered reasonable. Consequently, MNA was retained to further examine its feasibility. Finally, monitoring and ICs are also considered in this report since both remedial options appear to be necessary components of any remedy selected for the GWOU.

The remainder of this report is organized as follows:

- Section 2 provides site background information useful in understanding the evaluations presented in this report.

- Section 3 presents the reevaluation of technologies and identifies the final alternatives for the GWOU.

- Section 4 provides an analysis of the three final alternatives.

- Section 5 presents a preliminary design for the preferred alternative. 


\section{SITE BACKGROUND}

The Weldon Spring Chemical Plant area is about 88 ha (217 acres) and lies within the boundaries of the former Weldon Spring Ordnance Works, which is about 6,974 ha (17,232 acres). Both sites are on the EPA's National Priority List. The remediation of the former Weldon Spring Ordnance Works is being conducted by the DA. The contamination at the Ordnance Works site is primarily in the form of nitroaromatic compounds. The Chemical Plant was used for trinitrotoluene (TNT) and dinitrotoluene (DNT) production from 1941 to 1945, and later, from 1957 to 1966, it was used as a uranium processing facility. The sources of groundwater contamination have been remediated. These consisted of some 40 buildings, four Raffinate Pits (radioactive and chemical waste retention ponds), two ponds (Ash Pond and Frog Pond), and two former dumps (north and south). Groundwater investigations that have been conducted include the following: (1) groundwater monitoring since 1987 (including a comprehensive remedial investigation [RI] in 1995), (2) dye-trace studies conducted in 1995 and 1998, (3) a pump test done in 1998, (4) field studies conducted in 2002 to evaluate enhanced groundwater removal technologies, and (5) ICO for TCE treatment conducted in 2001. The results of these investigations are incorporated into the discussions presented below.

Brief descriptions of the site geology, hydrogeology, surface water, land use, and groundwater use are presented in Sections 2.2.1 to 2.2.4 to facilitate an understanding of where contamination exists and where it could be transported and to determine the potential for exposure.

\subsection{CURRENT GROUNDWATER AND SPRING WATER CONDITIONS}

The current monitoring program consists of 86 wells (including five wells that monitor the performance of the Chemical Plant on-site disposal cell) and five springs. After 1986, approximately 60 additional monitoring wells were also constructed and sampled, but they have since been abandoned. The current network of wells monitored at the Chemical Plant area is shown in Figure 2.1.

\subsubsection{Groundwater}

The COCs in groundwater are TCE, nitrate, uranium, and nitroaromatic compounds. The nitroaromatic compounds of concern include 2,4-dinitrotoluene (2,4-DNT), 2,6-dinitrotoluene (2,6-DNT), 2,4,6-trinitrotoluene (2,4,6-TNT), 1,3-dinitrobenzene (1,3-DNB), and nitrobenzene (NB). Presentations of contaminant distributions in Figures 2.2 to 2.7 depict the locations where contaminants in groundwater exceed appropriate water quality standards or RBCs on the basis of averages for 2002 (2002 averages for 1,3-DNB and NB did not exceed their respective water quality standards). 


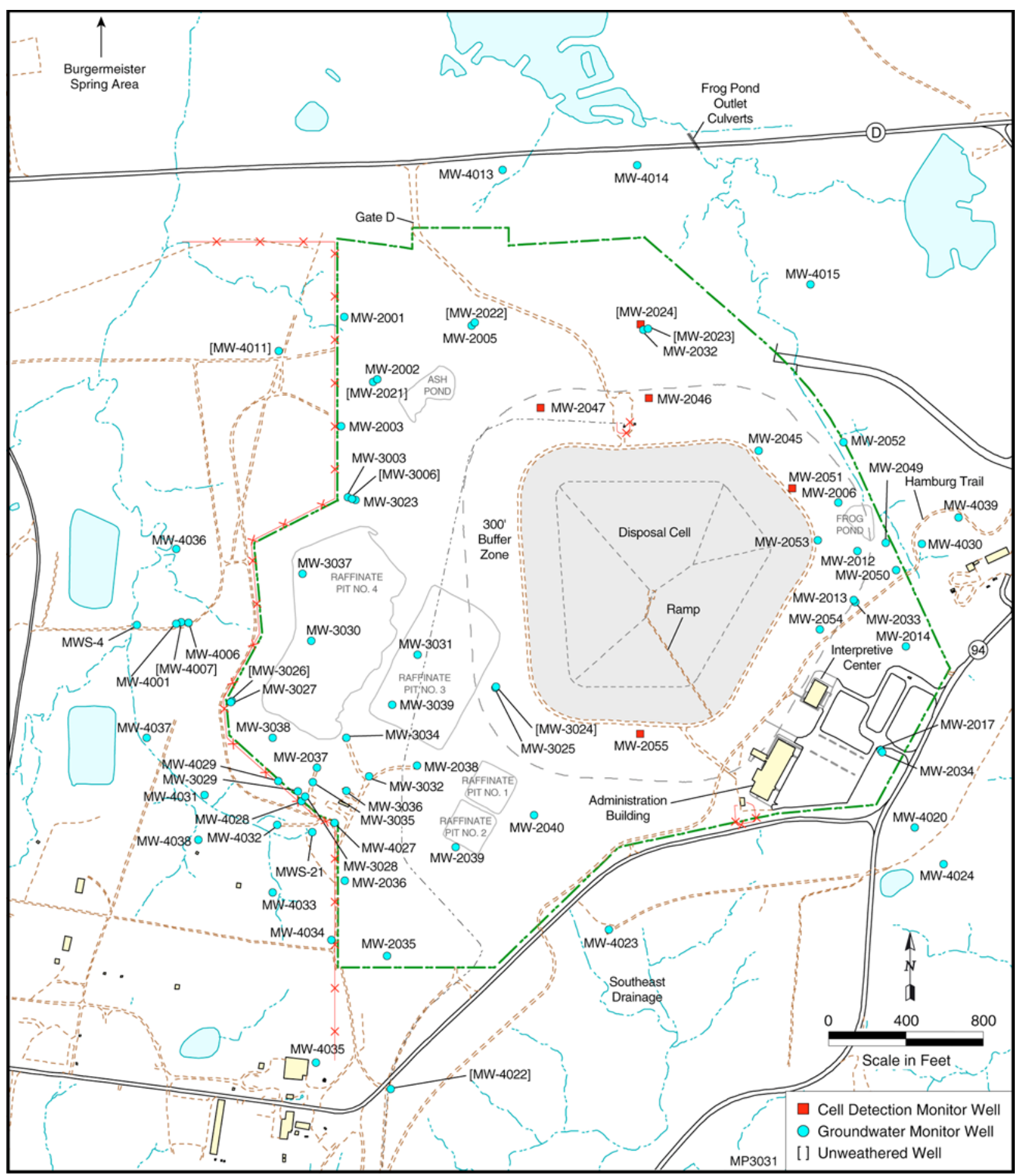

FIGURE 2.1 Locations of Monitoring Wells at the Chemical Plant Area 


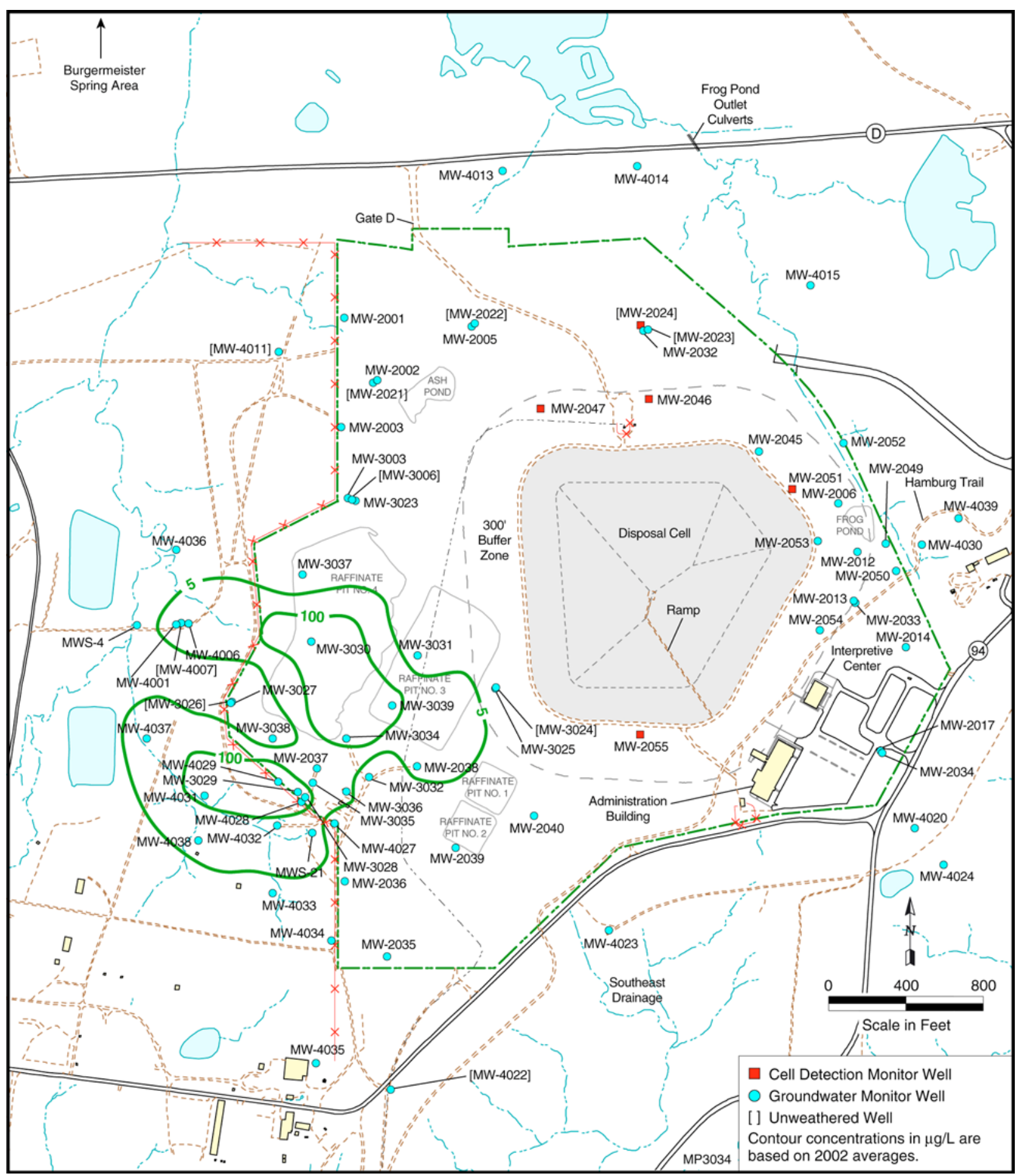

FIGURE 2.2 TCE Contamination Contour Based on Average Concentrations in 2002 at the Chemical Plant Area 


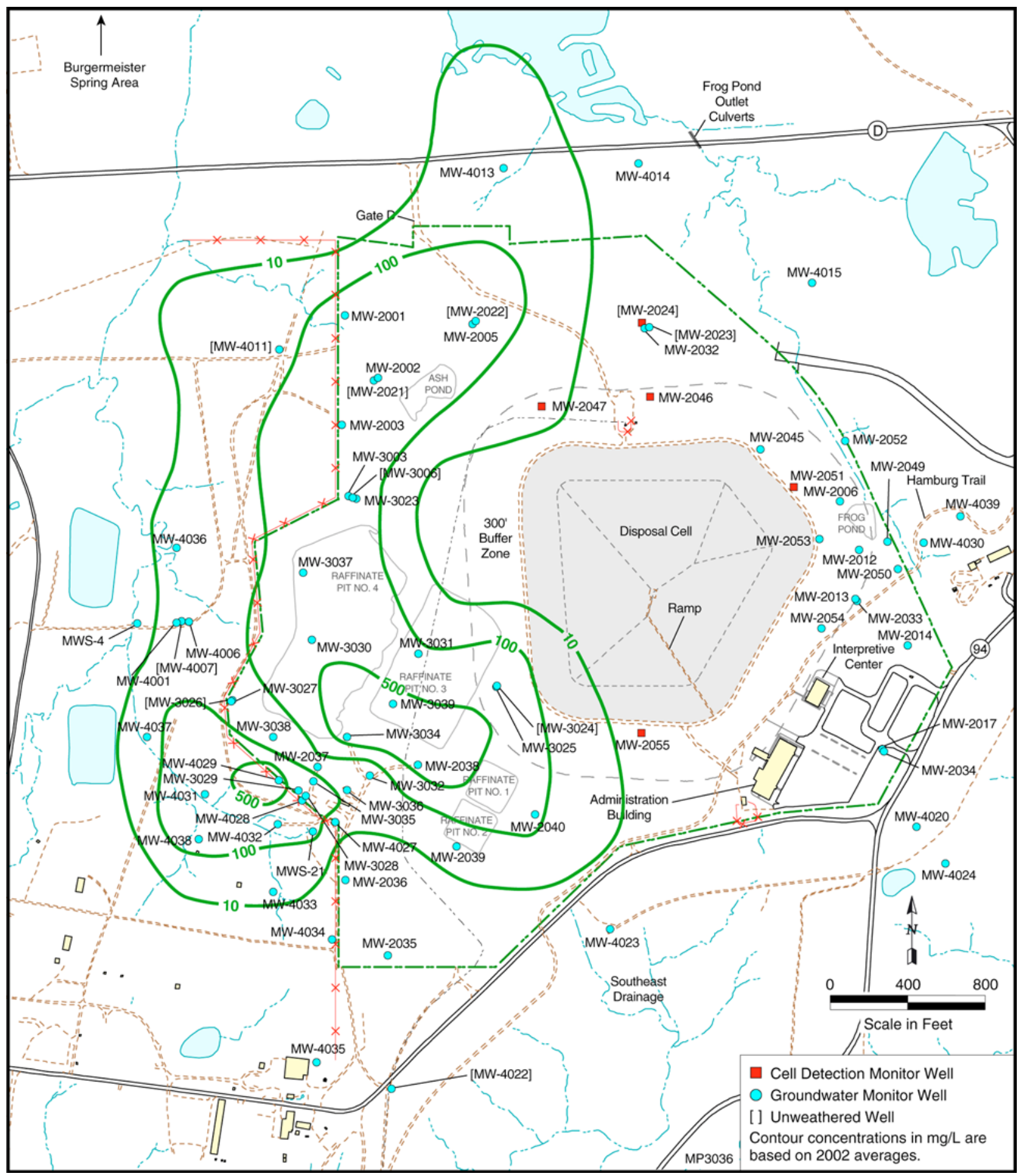

FIGURE 2.3 Nitrate Contamination Contour Based on Average Concentrations in 2002 at the Chemical Plant Area 


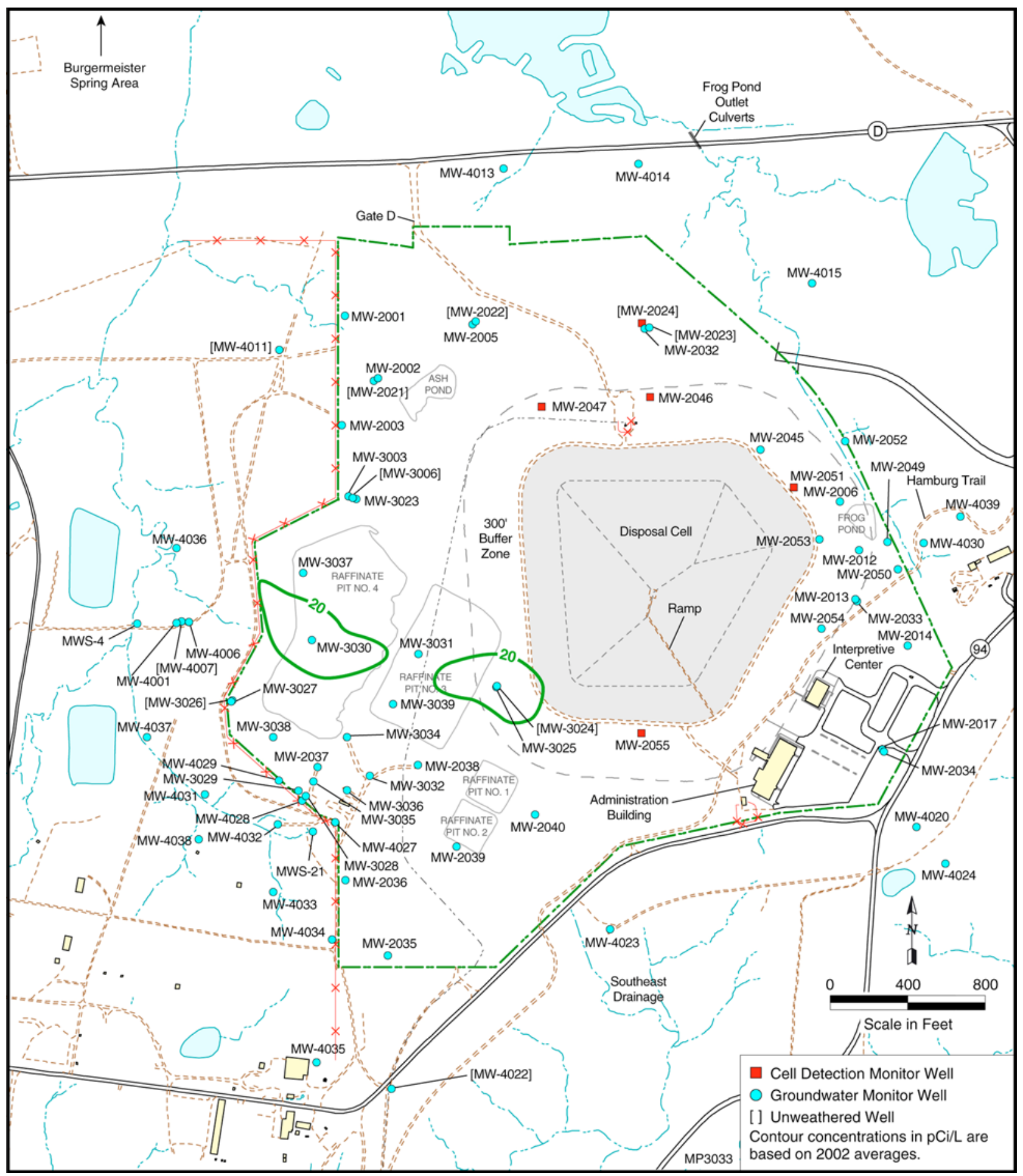

FIGURE 2.4 Uranium Contamination Contour Based on Average Concentrations in 2002 at the Chemical Plant Area 


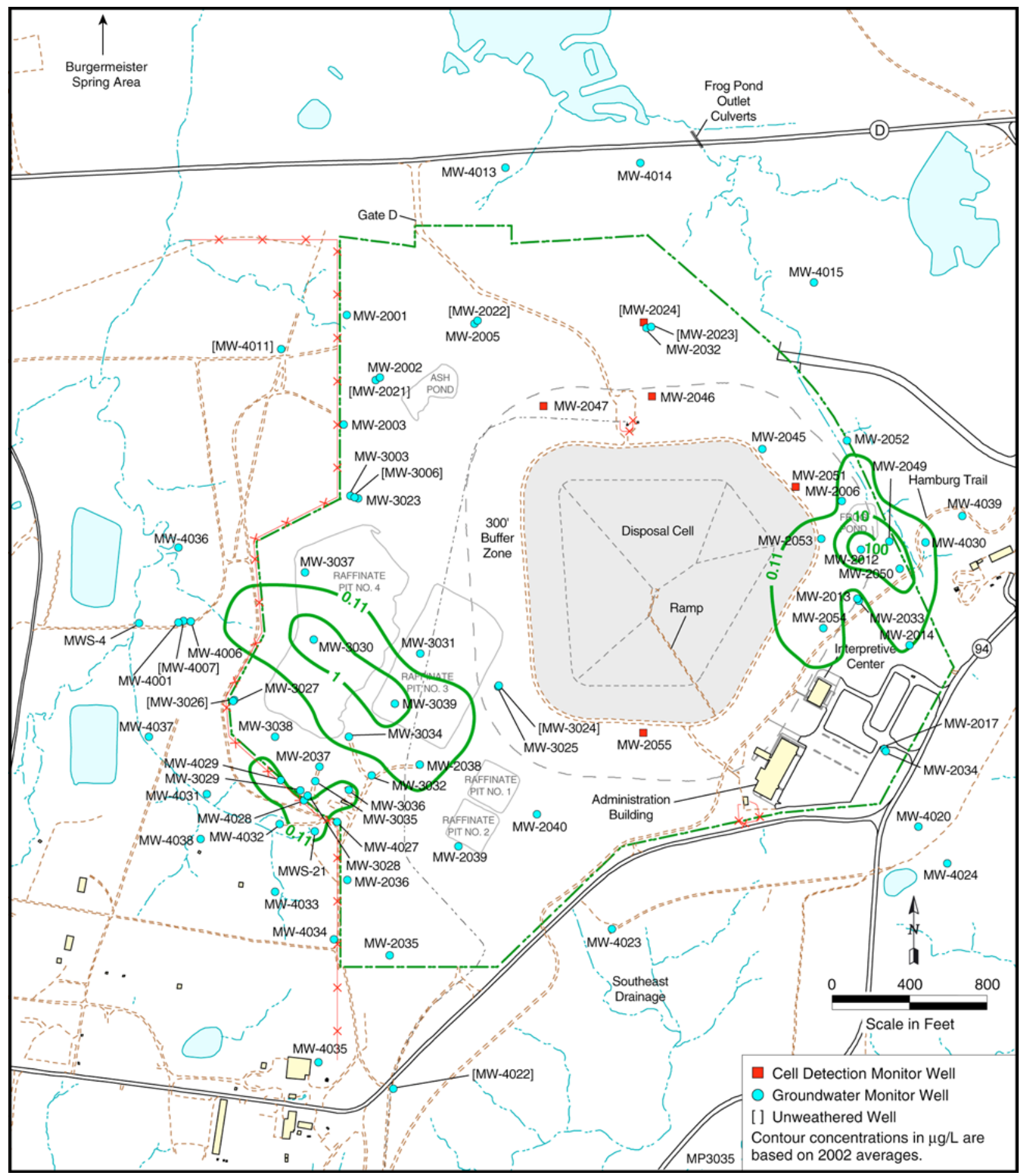

FIGURE 2.5 2,4-DNT Contamination Contour Based on Average Concentrations in 2002 at the Chemical Plant Area 


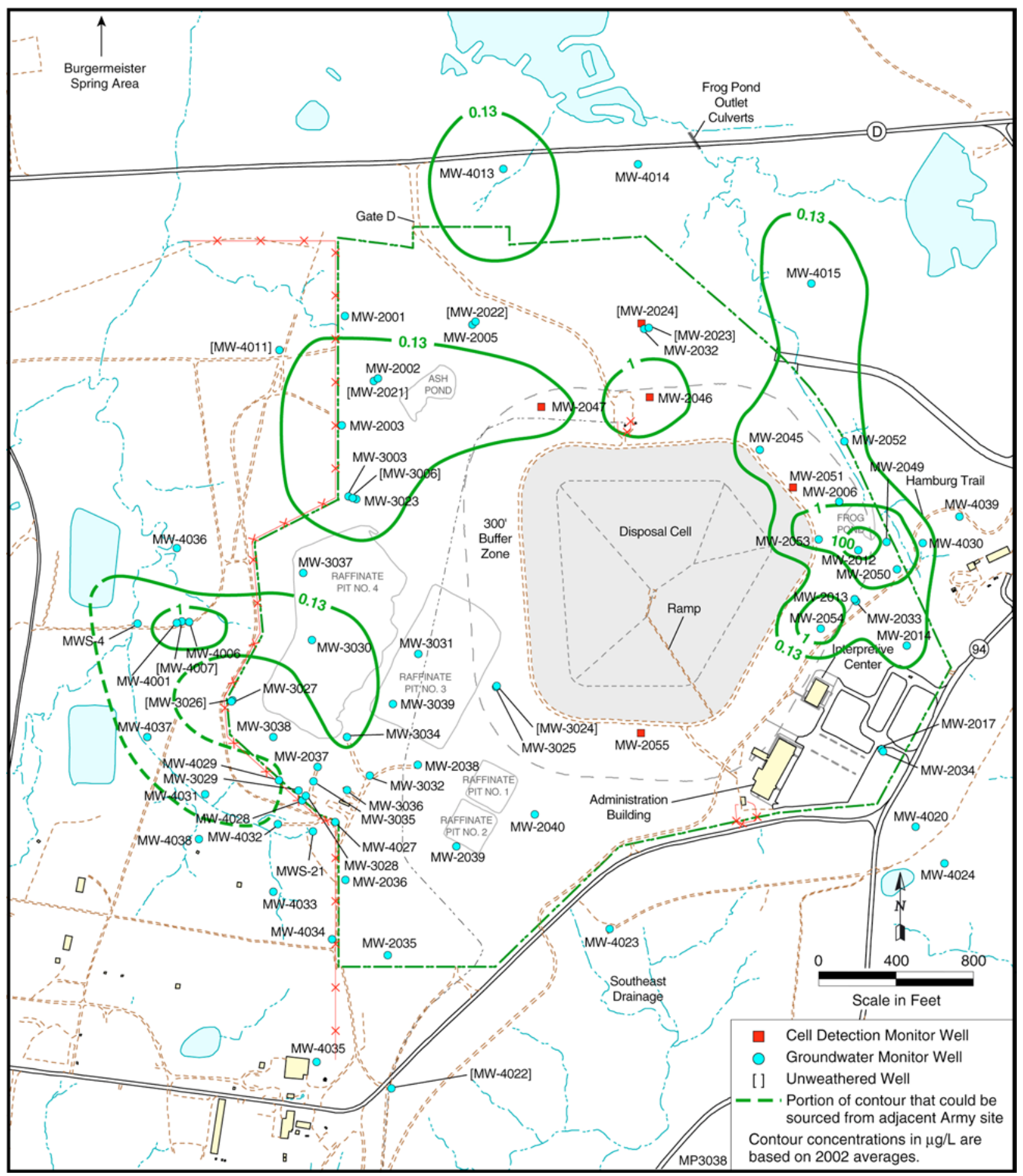

FIGURE 2.6 2,6-DNT Contamination Contour Based on Average Concentrations in 2002 at the Chemical Plant Area 


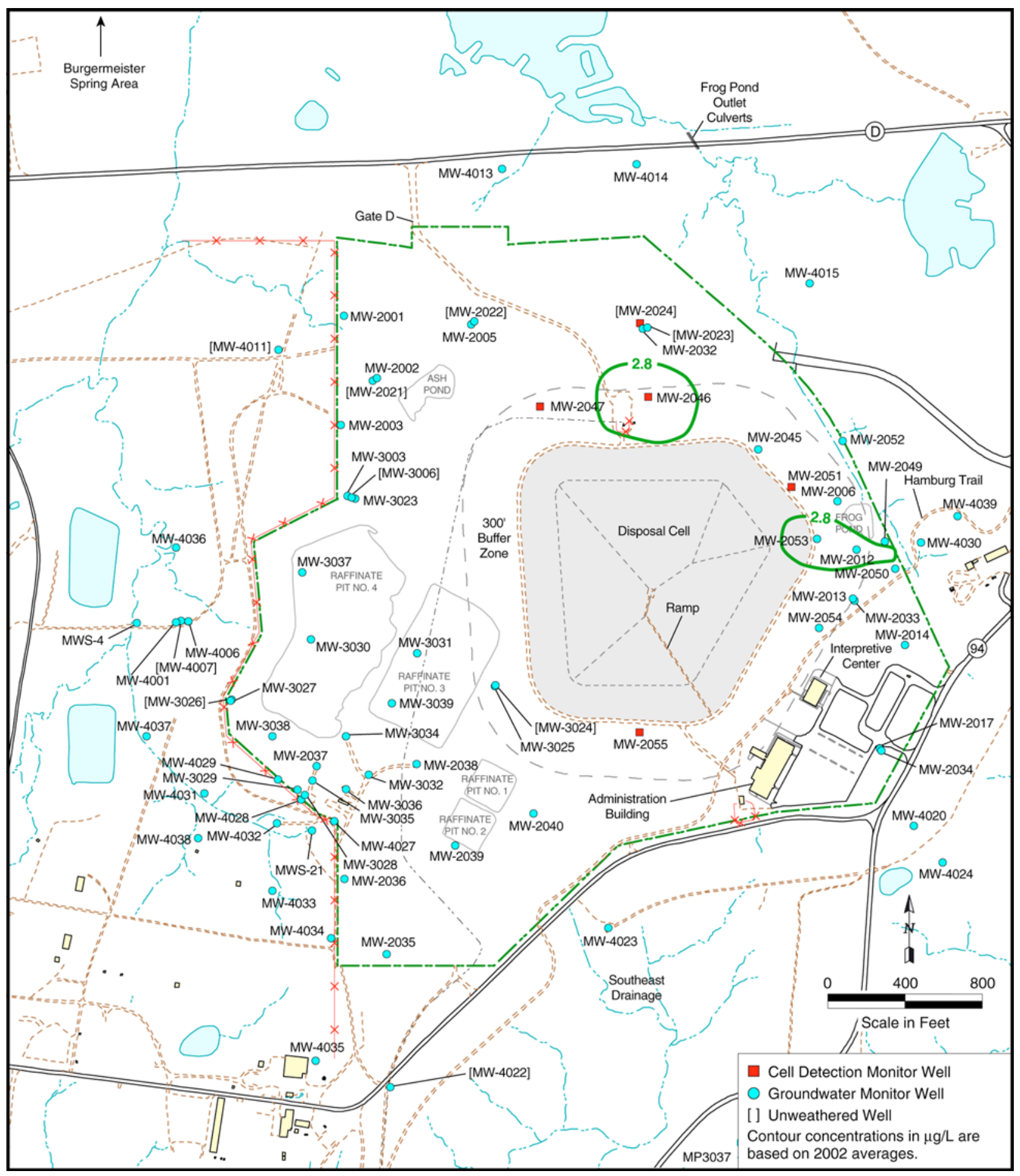

FIGURE 2.7 2,4,6-TNT Contamination Contour Based on Average Concentrations in 2002 at the Chemical Plant Area 
TCE contamination is primarily in the vicinity of the former Raffinate Pits. The horizontal extent of contamination extends from east of former Raffinate Pit 3 to the south and southwest of former Raffinate Pit 4, just beyond the boundary with the adjacent Army site. Contamination is primarily limited to the weathered portion of the shallow aquifer. The source of TCE contamination was drums discarded in Raffinate Pit 4. Decreasing trends since 1996 have been observed (maximum reported concentration then was $1,100 \mu \mathrm{g} / \mathrm{L}$ ); data collected in 2002 indicated a maximum concentration of $580 \mu \mathrm{g} / \mathrm{L}$, with the maximum level of TCE reported for MW-4029.

During 2001, the pilot-phase ICO process was performed as stipulated in the IROD (DOE 2000). The pilot-phase ICO achieved a temporary reduction of TCE within the area of influence (approximately $30 \mathrm{~m}[100 \mathrm{ft}]$ from the injection point). Dispersion of the oxidant favored a downgradient direction toward a preferential flow feature (paleochannel), and uniform distribution was not achieved. Recent data (2003) collected at some locations where TCE was treated and reduced to nondetectable levels indicate that TCE levels are back at preapplication concentrations. This is likely due to recontamination from the TCE that is present in nearby portions of the shallow aquifer that were not within the area of influence for the pilot-phase ICO.

The highest concentrations of nitrate have typically been measured in the vicinity of the Raffinate Pits and Ash Pond, which are historical sources of this contaminant. Nitrates are mobile in the shallow aquifer system. Recent data (2002) show a range of 0.4 to $826 \mathrm{mg} / \mathrm{L}$, with the maximum reported for MW-4029. Remediation activities in the Raffinate Pits area and Ash Pond in 1998 resulted in slight increases in contaminant concentrations in several of the wells in the vicinity. The majority of the wells exhibit stationary trends, with a few beginning to show downward trends.

Uranium contamination occurs predominantly on the Chemical Plant site in the weathered unit of the Burlington-Keokuk Limestone. The Raffinate Pits were the historical source of uranium in groundwater as it entered the aquifer via infiltration through the overburden. The adsorption of uranium onto the overburden limited its extent in the groundwater. Recent data collected for uranium in 2002 ranged from 0.1 to $60 \mathrm{pCi} / \mathrm{L}$, and concentrations in only two wells exceeded the recently promulgated MCL of $30 \mu \mathrm{g} / \mathrm{L}$ (or $20 \mathrm{pCi} / \mathrm{L}$ based on the isotopic ratio determined for the Weldon Spring site). These wells are MW-3024 (at $60 \mathrm{pCi} / \mathrm{L}$ ) and MW-3030 (at $57 \mathrm{pCi} / \mathrm{L}$ ). Because of the relatively low concentrations, downward trends are not expected to be clearly established until several more years of groundwater data are collected following remediation of the Raffinate Pits.

Nitroaromatic compounds occur in groundwater in the northeastern and southwestern portions of the site, where TNT production lines were located both on the Chemical Plant site and off site. Contamination occurs predominantly in the weathered unit of the aquifer. In 2002, maximum concentrations of 1,600 $\mu \mathrm{g} / \mathrm{L}$ for $2,4-\mathrm{DNT}, 1,300 \mu \mathrm{g} / \mathrm{L}$ for 2,6-DNT, $290 \mu \mathrm{g} / \mathrm{L}$ for 2,4,6-TNT, $1.7 \mu \mathrm{g} / \mathrm{L}$ for $1,3-\mathrm{DNB}$, and $69 \mu \mathrm{g} / \mathrm{L}$ for NB were detected. These maximums have been reported for one well in particular, MW-2012. Starting in 1999, upward trends were observed from this monitoring well near the Frog Pond area. They are most likely the result of the excavation of TNT-impacted soil in this area or in the nearby waste lagoon excavated by the Army and are expected to be temporary. 


\subsubsection{Spring Water}

Springs that are influenced by historical Chemical Plant surface water runoff, historical process sewer effluent, or groundwater that contains one or more of the COCs have been routinely monitored. The primary contaminants in the spring water at surface springs around the Chemical Plant area are uranium, nitrate, and nitroaromatic compounds. Low concentrations of TCE (less than $1.1 \mu \mathrm{g} / \mathrm{L}$ ) have been detected only occasionally in one spring, SP 6303. Historical data on concentrations of uranium near springs indicate that during storm events, contaminated soil was transported from the Chemical Plant area in surface water runoff. The uranium was transported in both dissolved and particulate forms. In the drainages downstream from the Chemical Plant, surface water infiltrated the subsurface through losing stream sections, where a portion of the contaminated sediment was deposited in fractures and solution features.

The presence of elevated uranium and nitrate levels at Burgermeister Spring, located $1.9 \mathrm{~km}(1.2 \mathrm{mi})$ north of the site, indicates that discrete flow paths are present in the vicinity of the site. Groundwater tracer tests performed in 1995 (DOE and DA 1997b) indicated that a discrete and rapid hydraulic connection exists between the northern portion of the Chemical Plant and this spring. However, the uranium presence was predominantly the result of historical surface water runoff and resultant residual contamination in the fractured bedrock, since uranium concentrations in the spring are typically higher than those measured in groundwater.

In Burgermeister Spring, uranium levels ranged from 8.6 to $100 \mathrm{pCi} / \mathrm{L}$ during 2002. Uranium concentrations measured at Burgermeister Spring are generally greater than those measured in groundwater at the Chemical Plant. Base flow concentrations have shown a downward trend at Burgermeister Spring since 1999 and a stationary trend in high flow conditions. Nitrate concentrations at Burgermeister Spring vary with changes in the flow rate, but they are generally lower than concentrations measured in groundwater. Lower concentrations occur during high flow rates because of dilution. Nitrate data from 2002 indicate a range of 0.94 to $11 \mathrm{mg} / \mathrm{L}$. Nitrate results from Burgermeister Spring (1999 through 2002) show a downward trend during high flow and a stationary trend during base (low) flow. Of the nitroaromatic compounds analyzed, only 2,6-DNT has been detected in Burgermeister Spring.

In the Southeast Drainage Spring, SP-5304, uranium and nitroaromatic compounds have been routinely detected. Uranium concentrations at SP-5304 ranged between 9.4 and $103 \mathrm{pCi} / \mathrm{L}$ during 2002. Of the nitroaromatic compounds analyzed, only 2,4,6-TNT was detected in this spring. Nitrate and TCE were not detected in this spring.

\subsection{SITE SETTING}

\subsubsection{Geology and Hydrogeology}

Two major geologic units are present beneath the Chemical Plant area: unconsolidated surface materials and underlying limestone bedrock. Unconsolidated surface materials as much as $18 \mathrm{~m}(60 \mathrm{ft})$ thick are clay rich and mostly of glacial origin. The uppermost bedrock unit in the 
area, the Burlington-Keokuk Limestone, has been separated into two zones with different physical characteristics: weathered zone underlain by unweathered zone. The weathered unit ranges in thickness from 3 to $17 \mathrm{~m}$ (10 to $55 \mathrm{ft}$ ), and it consists of highly fractured limestone with solution voids and enlarged fractures. Fracturing in the bedrock is predominantly horizontal. Solution features are common in the weathered portion of the Burlington-Keokuk Limestone and

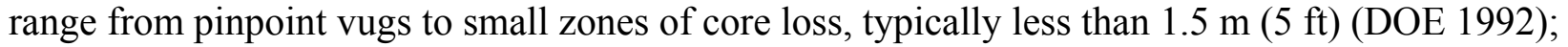
however, these features are generally clay filled. Zones of deeper weathering coincide with the locations of vertical fractures. Significantly fewer horizontal and vertical fractures exist in the unweathered unit than in the weathered unit. Field data indicate a decrease in hydraulic conductivity with depth, due to decreased weathering. The size, abundance, geometry, and connection of the open fractures within the bedrock affect the transport of groundwater and contaminants through the bedrock

There are three regional aquifers in the vicinity of the Chemical Plant area: a shallow unconfined aquifer (although it may be locally confined), a middle confined aquifer, and a deep confined aquifer. The shallow unconfined aquifer has been affected by former activities at the Chemical Plant area and is the groundwater system of primary interest. This aquifer consists of the Burlington-Keokuk Limestone and the Fern Glen Formation, both limestone units, and, to the north of the Chemical Plant, the overburden. Localized aquifer properties are controlled by fracture spacing and solution features in the weathered unit. Groundwater movement is controlled primarily by horizontal bedding planes, fractures, and solution features, resulting in limited downward movement into deeper formations. The underlying unweathered zone has decreased secondary porosity and lower hydraulic conductivity. Recharge to this shallow groundwater system is through infiltration of precipitation from the overburden or from losing streams. The water table elevation fluctuates with precipitation but remains within the upper bedrock or overburden to the north of the Chemical Plant.

An east-west-trending groundwater divide results in two distinct drainage systems in the Chemical Plant area. This divide is presently located along the southern boundary of the Chemical Plant property. Previously, the divide was situated beneath the Raffinate Pits area because of the extensive recharge from the pits, which have since been removed. At the Chemical Plant area, shallow groundwater north of the divide flows to the north and into a karst conduit system that discharges at Burgermeister Spring (Figure 2.8). Transport through this conduit can be very rapid, as demonstrated by subsurface dye trace studies performed at the Chemical Plant site in 1995 and 1998 (DOE and DA 1997b). Water discharged at Burgermeister Spring then mixes with other surface water and with ponded water in Lake 34. Any dissolved contaminants in the discharged groundwater are then subject to extensive dilution and physical and chemical degradation. Because most of the shallow groundwater beneath the Chemical Plant area discharges to the surface in the vicinity of Burgermeister Spring, the spring defines the northernmost extent of direct groundwater transport from the site and provides an ideal location for monitoring end point contaminant concentrations.

Groundwater south of the divide at the Chemical Plant area flows south to southeast toward the Missouri River, primarily through the Southeast Drainage. Presently, no groundwater contamination attributable to the Chemical Plant site is present south of the divide; therefore, 


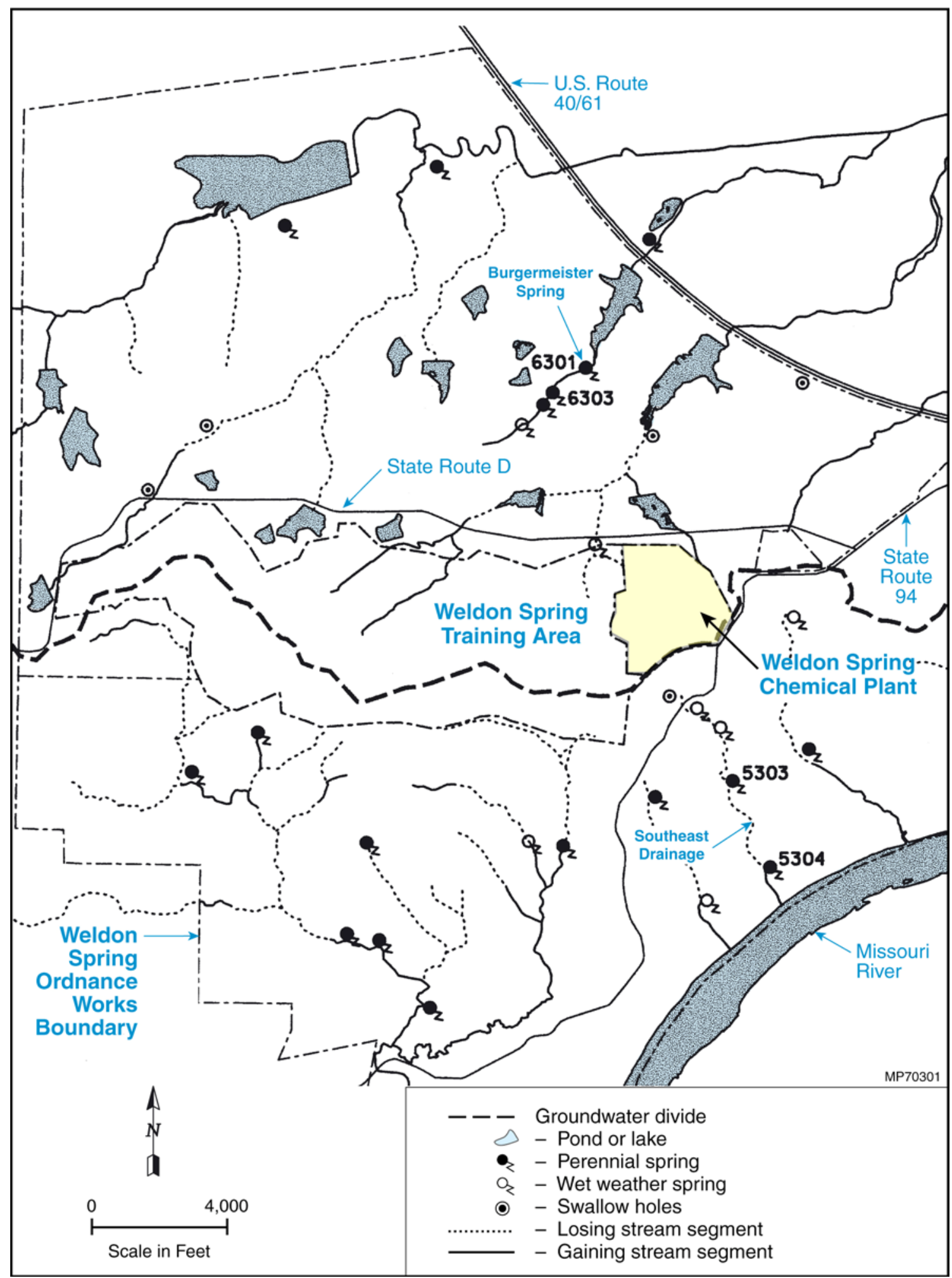

FIGURE 2.8 Locations of Springs and Drainage Areas in the Chemical Plant Area 
there is no groundwater component to the contamination present in the downgradient springs. Historically, contaminated groundwater from Raffinate Pits 1 and 2 flowed into the Southeast Drainage. This drainage was used as a discharge point for effluent from the Chemical Plant operations, and, because this drainage has losing stream segments in its upper reaches, mixing between groundwater and surface water occurred. Like Burgermeister Spring, springs in the Southeast Drainage act as end points of direct groundwater transport from the Chemical Plant area and provide ideal locations for monitoring groundwater contamination. Data from groundwater downgradient of the springs indicate no impact.

The shallow groundwater system beneath the Chemical Plant area is hydrogeologically complex and characterized by fractures, conduits, paleochannels, and dissolution/weathering features. Because of these features, the aquifer exhibits highly heterogeneous and anisotropic values in conductivity and transmissivity (i.e., the ease with which a porous material allows water to flow) from place to place. Pump tests performed in July 1998 to determine the effects of groundwater withdrawal on the aquifer further demonstrated the variability of the aquifer (MK-Ferguson Company and Jacobs Engineering Group 1998). In one location, pumping at a rate of less than $3.8 \mathrm{~L} / \mathrm{min}$ (1 gallon per minute or gpm) could not be sustained. In a second location approximately $30 \mathrm{~m}(100 \mathrm{ft})$ away, water could be pumped but only at a rate of less than $38 \mathrm{~L} / \mathrm{min}(10 \mathrm{gpm})$. Even at this low rate of pumping, the shallow groundwater system could not recharge quickly enough to sustain this rate, which resulted in the water level in the well falling below the depth of the pump. Once pumping stopped, recovery of the groundwater level was very slow, and full recovery to water levels prior to testing was achieved about 1 year later. These findings were further supported by a subsequent field study performed in 2001 to evaluate using artificial recharge to facilitate sustained pumping of the aquifer. Both of these studies support the conceptual groundwater flow model, which assumes that sustainable yields from wells are low and that localized dewatering is likely.

\subsubsection{Surface Water}

The Chemical Plant area is located on an east-west surface water drainage divide between the Missouri and Mississippi watersheds. At the Chemical Plant area, surface drainage to the south of the divide generally flows through the Southeast Drainage and discharges to the Missouri River. Surface drainage to the north of the divide flows toward Dardeene Creek and its tributaries. Schote Creek, the largest of the tributaries, drains a major portion of the Chemical Plant area. Dardenne Creek flows east to the Mississippi River (see Figure 2.8). Surface drainage north of the Chemical Plant can be lost to losing stream segments and can discharge to nearby springs, primarily Burgermeister Spring.

\subsubsection{Land Use}

The two communities closest to the site are Weldon Spring and Weldon Spring Heights, about $3.2 \mathrm{~km}(2 \mathrm{mi})$ to the northeast. The combined population of these two communities is about 5,000. No private residences exist between Weldon Spring Heights and the site. Urban areas occupy about $6 \%$ of county land, and nonurban areas occupy $90 \%$; the remaining $4 \%$ is 
dedicated to transportation and water uses (MK-Ferguson Company and Jacobs Engineering Group 2001). Francis Howell High School (FHHS) is about $1 \mathrm{~km}(0.6 \mathrm{mi})$ northeast of the site along Missouri State Route 94 and is occupied regularly by about 1,700 faculty, staff, and students.

The Missouri Highway and Transportation Department (MoDOT) Weldon Spring maintenance facility, located adjacent to the north side of the Chemical Plant, employs about 10 workers. The Army Reserve Training Area to the west of the site is visited periodically by Army trainees and law enforcement personnel (MK-Ferguson Company and Jacobs Engineering Group 2001). About 300 ha (741 acres) of land east and southeast of the high school is owned by the University of Missouri. The northern third of this land is being developed into a hightechnology research park. The conservation areas adjacent to the site are operated by the Missouri Department of Conservation (MDC) and employ about 50 people. Two residences are located on the MDC property north of the Chemical Plant.

\subsubsection{Groundwater Use}

As a whole, the shallow aquifer beneath the boundaries of the Chemical Plant area and the adjacent former Ordnance Works area is currently not used for drinking water or for irrigation. However, on the basis of EPA guidance for groundwater classification (EPA 1986), site groundwater could be classified as potentially usable from a water quality standpoint. (According to the EPA, a potential source of groundwater is one capable of yielding at least $568 \mathrm{~L} / \mathrm{d}$ [150 gal/d] to a well or spring, which is sufficient for the needs of a family.) Also, a drinking water source must have a total dissolved solids concentration of less than 10,000 mg/L that can be supplied without treatment (MK-Ferguson Company and Jacobs Engineering Group 1990).

No active private wells are located within $1.6 \mathrm{~km}(1 \mathrm{mi})$ of the Chemical Plant. One well, which is used for irrigation at the Missouri Research Park, is located within $3.2 \mathrm{~km} \mathrm{(2} \mathrm{mi),} \mathrm{but} \mathrm{it}$ is cross gradient of the site and therefore does not have the potential for impact. No domestic wells are known to be active within the Chemical Plant area, the adjacent Ordnance Works area, or the Busch Conservation area (Vogel 2003). The closest domestic water wells from the site are located $3.4 \mathrm{~km}(2.1 \mathrm{mi})$ to the north-northeast. These wells are estimated to be 70 to $91 \mathrm{~m}$ (325 to $350 \mathrm{ft}$ ) below the ground surface. Although these wells produce water from the shallow aquifer, the potential for impact from contaminated groundwater originating from the Chemical Plant site is low. Groundwater field studies have supported that the preferential flow direction for groundwater from the site is to the northwest toward Burgermeister Spring and the 6300 Drainage (DOE and DA 1997b). If active wells were present between the site and this drainage, the likelihood for impact would be high.

The Missouri Department of Health and Senior Services (DHSS), which was at the time called the Missouri Department of Health $(\mathrm{MDOH})$, initiated a sampling program for private drinking water wells surrounding the Weldon Spring site in 1982. The number of wells was expanded over time in an effort to fully investigate the area around the Chemical Plant and the former Army Ordnance Works area. When a well is no longer used for consumption, it is 
removed from the sampling program. In 2003, the DHSS will sample several wells within approximately $9.7 \mathrm{~km}(6 \mathrm{mi})$ of the Chemical Plant area. Historically, wells closer to the site were sampled quarterly and those in outlying areas were sampled annually. Presently, wells are sampled on an annual frequency. Sampling results indicate background levels of those parameters analyzed, including radiological parameters (Basko 2003). The only historically impacted wells identified were at Twin Island Lakes (Dardenne Lakes) located northeast of the Chemical Plant area and Ordnance Works area, where elevated nitroaromatic compounds were detected. This impact is not due to the DOE Weldon Spring site and was investigated by the DA as part of its Ordnance Works Comprehensive Environmental Response, Compensation, and Liability Act (CERCLA) site activities.

The current source of water for the majority of residents in the area is municipal water provided by several companies. County zoning for future housing developments in the area around the Chemical Plant and adjacent Ordnance Works indicate that when available, municipal water would continue to be the source of drinking water, even for potential future residents in the area.

\subsubsection{Summary of Risk}

As part of the RI/FS (DOE and DA 1997b, 1998), standard EPA methods were used to evaluate potential risks to human health and the environment from groundwater and spring water contamination. Risk scenarios for the human health evaluation were developed on the basis of current and likely future land uses. Both carcinogenic and noncarcinogenic effects were evaluated. Foreseeable future land use at the Chemical Plant and surrounding area is likely to be recreational (as is current land use), which means potential exposure would come only through access to spring water. The assessment presented in the baseline risk assessment (BRA) (DOE and DA 1997a) also provided risk estimates for a hypothetical future resident scenario that assumes access to groundwater contaminants. The Army reservists scenario (which accounts for reservists who train at the adjacent Army training area) was not evaluated because the reservists do not have access to any active springs within the training area. The exposure assumptions (e.g., frequency and duration) for the recreational visitor scenario would account for instances when these reservists might access the springs outside the training area while on personal time.

For the recreational visitor scenario, the assessment assumed conservatively that the recreational visitor would visit the area 20 times a year for 30 years for 4 hours on each visit and each time would ingest a cupful of spring water. For the hypothetical (adult) resident scenario, the assessment assumed that the resident would ingest groundwater from each well for 350 days a year for 30 years by drinking 2 liters per day. In addition, because the toxic effect of nitrate (i.e., methemoglobinemia, or low blood oxygen levels) is primarily of concern for infants, a separate hazard index was calculated for infants ingesting groundwater. The calculation assumed an ingestion rate of $0.64 \mathrm{~L} / \mathrm{d}$ and a body weight of $4 \mathrm{~kg}$ (compared with the adult intake of $2 \mathrm{~L} / \mathrm{d}$ and body weight of $70 \mathrm{~kg}$ ). The results show that the hazard index for the infant due to nitrate would be higher by a factor of 5.6 than the hazard index calculated for an adult receptor. 
For the BRA, the hazard indices estimated for a recreational visitor at the springs (including SP6301, which is Burgermeister Spring) ranged from less than 0.001 to 0.2; the risk of developing cancer for the recreational visitor scenario at the springs (from the combined

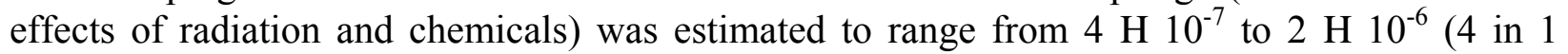
billion to 2 in 1 million). Post-BRA estimates (using data from 1998 to 2002) indicate a range of

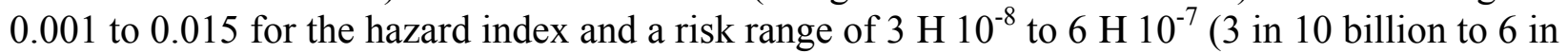
1 billion) from the combined effects of radiation and chemicals. Average data reported for Burgermeister Spring in 2002 indicated levels of $29 \mathrm{pCi} / \mathrm{L}$ for uranium and $3.5 \mathrm{mg} / \mathrm{L}$ for nitrate.

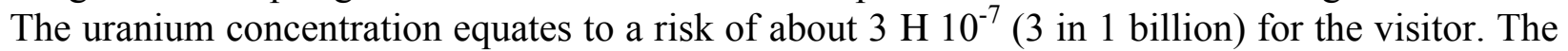
nitrate concentration equates to a hazard quotient of less than 0.001 for the adult visitor and 0.002 for the infant visitor. The sum of the hazard quotients (i.e., hazard index) for the adult visitor at the Burgermeister Spring is about 0.002 (accounting for the effects of uranium and nitrate). These risk estimates indicate that the recreational visitor ingesting spring water from the springs (including Burgermeister Spring) with site contamination would not be at increased risk for cancer and would not have adverse noncarcinogenic effects from site contaminants. The EPA has defined a hazard index of greater than 1 as indicating possible adverse noncarcinogenic health effects. For known or suspected carcinogens, the EPA has determined that acceptable exposure levels present an excess lifetime cancer risk to an individual of between $1 \mathrm{H} 10^{-4}$ and $1 \mathrm{H}^{-6}$ ( 1 in 10,000 and 1 in 1 million).

For the hypothetical resident scenario, estimates in the BRA indicated hazard indices of greater than 1 for several wells (43 out of 155 wells), primarily as a result of nitrate and nitroaromatic compounds; the calculations for the infant child resident scenario indicated 5 more wells would exceed the hazard index of 1 because of nitrate. The range was reported to be from less than 0.01 to 40 for the adult resident. The post-BRA (1998 to 2002) estimates range from less than 0.001 to 44 , with estimates for 40 wells being greater than 1 primarily as a result of nitrate.

In the BRA, risk estimates for groundwater for the hypothetical resident scenario indicate the following: (1) TCE in three wells near the Raffinate Pits area could result in risk greater than $1{\mathrm{H} 10^{-4}}^{(1}$ in 10,000 ) (at $3{\mathrm{H} 10^{-4}}^{-4} 1{\mathrm{H} 10^{-3}}^{-3}$; (2) nitroaromatic compounds in one well could result in risk greater than $1{\mathrm{H} 10^{-4}}^{(1}$ in 10,000); and (3) uranium in six wells could result in risk

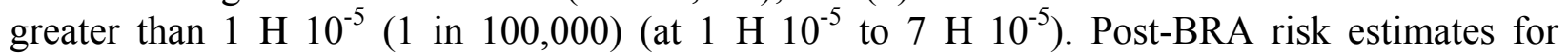
groundwater for the hypothetical resident scenario indicate that TCE concentrations in several of the monitoring wells near the Raffinate Pits area could potentially result in human health risks greater than $1{\mathrm{H} 10^{-4}}^{(1}$ chance in 10,000). 2,4-DNT and 2,6-DNT concentrations near the Frog

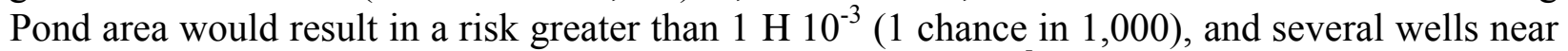

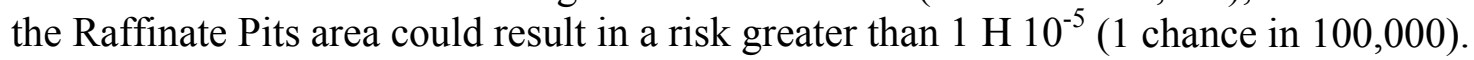

The risk calculations indicate that the site contamination levels would be acceptable for the recreational visitor but would not be acceptable for a resident. In addition, groundwater concentrations for TCE, nitrate, uranium, and some of the nitroaromatic compounds exceed federal or state drinking water standards or MCLs. Therefore, restrictions on the use of groundwater will be necessary to protect human health until that time when contaminant concentrations have been reduced to levels equivalent to or below the MCLs. 
The results of the ecological assessment indicate that contaminant concentrations in spring water and sediment pose little or no risk to ecological resources of the area and that remediation is not needed from an ecological perspective (DOE and DA 1997a).

Biotic surveys of macroinvertebrates, fish, and amphibians that inhabit the Burgermeister Spring drainage indicated no evidence of adverse effects. The spring was determined to contain generally good aquatic habitat, and the species present are typical of those found in similar habitats throughout the Midwest. Under low flow conditions, which commonly occur in the summer, the stream drainage below the spring becomes intermittent, and portions of the habitat become dry. Surveys of amphibians found a community typical of those found in similar habitats in the Midwest. Fish tissue analyses revealed relatively low levels of contaminant bioconcentrations, all below levels of concern.

\subsubsection{Remedial Action Objectives}

The remedial action objectives (RAOs) for the GWOU are as follows. (1) Provide protection of human health and the environment by attaining applicable or relevant and appropriate requirements (ARARs), including chemical-specific ARARs, and by reducing concentrations of COCs that have no ARARs to within the acceptable risk range. Risk-based concentrations (RBCs) equivalent to this range have been developed. (2) Ensure that land use remains consistent with groundwater and spring water use restrictions.

For the groundwater COCs, the following ARARs and RBCs have been identified: (1) $5 \mu \mathrm{g} / \mathrm{L}$ for TCE as a chemical-specific ARAR based on the federal MCL for drinking water; (2) $10 \mathrm{mg} / \mathrm{L}$ for nitrate as a chemical-specific ARAR based on the federal MCL for drinking water; (3) $20 \mathrm{pCi} / \mathrm{L}$ for uranium as a chemical-specific ARAR based on the recently promulgated federal MCL of $30 \mu \mathrm{g} / \mathrm{L}$ (the conversion to $20 \mathrm{pCi} / \mathrm{L}$ takes into account the isotopic ratios of uranium established for the Weldon Spring site); (4) $0.11 \mu \mathrm{g} / \mathrm{L}$ for $2,4-\mathrm{DNT}, 1.0 \mu \mathrm{g} / \mathrm{L}$ for 1,3-DNB, and $17 \mu \mathrm{g} / \mathrm{L}$ for NB as chemical-specific ARARs based on State of Missouri water quality standards; and (5) 0.13 to $13 \mu \mathrm{g} / \mathrm{L}$ for $2,6-\mathrm{DNT}$ and 2.8 to $280 \mu \mathrm{g} / \mathrm{L}$ for $2,4,6-\mathrm{TNT}$ as the $\mathrm{RBC}$ ranges based on equivalent concentrations of each of the contaminants to a risk range of 1 in 1 million to 1 in 10,000 . 


\section{REEVALUATION OF TECHNOLOGIES AND IDENTIFICATION OF FINAL ALTERNATIVES}

In addition to the three technologies (groundwater removal, ICO of TCE, and MNA) listed in Section 1, monitoring and ICs are also reevaluated in this report. These five technologies and remedial options are considered in order to identify alternatives for the GWOU. The last two technologies were also retained as viable technologies in the evaluation presented in the FS (DOE and DA 1998). Treatment technologies, which would be a necessary component for a groundwater removal remedy, are not reevaluated in this report since select treatment technologies (e.g., GAC and ion exchange) have been proven to be implementable. As provided by the EPA's FS guidance, potential technologies and remedial options are initially screened against the following criteria.

1. Effectiveness: In terms of protecting human health and the environment in both the short and long term; minimizing toxicity, mobility, or volume; complying with ARARs; and achieving protection in a reasonable time frame;

2. Implementability: In terms of technical feasibility, resource availability, and administrative feasibility; and

3. Cost: In terms of expense (i.e., low, moderate, or high) over both the short term (i.e., capital costs) and the long term (i.e., operation and maintenance $[\mathrm{O} \& \mathrm{M}]$ costs), for technologies having similar performance and/or implementability.

\subsection{GROUNDWATER REMOVAL}

The removal of groundwater by conventional (vertical) extraction wells was evaluated in the FS. Although this technology was retained in the screening phase and included as a component for four of the nine preliminary alternatives identified in the FS, it was not deemed to be a viable response option because of field limitations that were indicated by the hydrogeologic data available at that time.

At the request of the MDNR, DOE conducted additional groundwater field studies in 2001 to obtain data to determine whether using artificial recharge in conjunction with groundwater extraction, or using an angled well for extraction, could significantly improve contaminant removal rates over those achieved by a conventional system (extraction using a vertical well with no artificial recharge). Variations that were evaluated included the injection of water to provide additional recharge to the aquifer and the use of an angled extraction well to increase the likelihood of intersecting any vertical flow paths in the subsurface.

The purpose of the field studies was thus to obtain field data to use in deciding whether the above-mentioned variations on a conventional groundwater extraction system could significantly improve removal rates over those achieved by a conventional system. A detailed 
discussion of the field studies is presented in the Completion Report for the Additional Groundwater Field Studies in Support of the Groundwater Operable Unit (MK-Ferguson Company and Jacobs Engineering Group 2002).

\subsubsection{Description of the Field Studies}

The design, construction, and operation of the field studies were coordinated with the EPA and MDNR. Four monitoring wells were installed in support of these field studies (Figure 3.1). In addition, two angled $\left(45^{\circ}\right)$ boreholes were drilled, and one was constructed into an extraction well. Drilling began on January 3, 2001, and development was completed on March 5, 2001. Drilling and well installation were performed to provide additional hydrogeologic characterization data related to the study area. After completion of pump installation in the newly constructed angled well and an existing vertical well, the groundwater field studies began on March 9, 2001.

The field studies involved six stages of testing to evaluate methods to improve a groundwater removal option for remediation of groundwater in the area near the former Raffinate Pits. The six stages were as follows:

1. Determine the sustainable yield of the shallow aquifer by the former Raffinate Pits area.

2. Extract groundwater at the sustainable yield to (a) establish a hydraulic capture zone in this area, (b) determine the aquifer response (verify boundaries), and (c) quantify the mass of contaminants removed by using conventional pumping methods.

3. Introduce artificial recharge at a predetermined rate $(5 \mathrm{gpm})$ and extract groundwater from the vertical well to (a) determine the increase in yield due to artificial recharge, (b) quantify the mass of contaminants removed by using artificial recharge, and (c) determine if providing artificial recharge to the aquifer increases the mass of contaminants removed.

4. Introduce artificial recharge at an increased rate $(10 \mathrm{gpm})$ and extract groundwater from the vertical well to (a) determine the increase in yield due to increased artificial recharge, (b) quantify the mass of contaminants removed by means of increased artificial recharge, and (c) determine whether increasing the amount of recharge increases the mass of contaminants removed. 


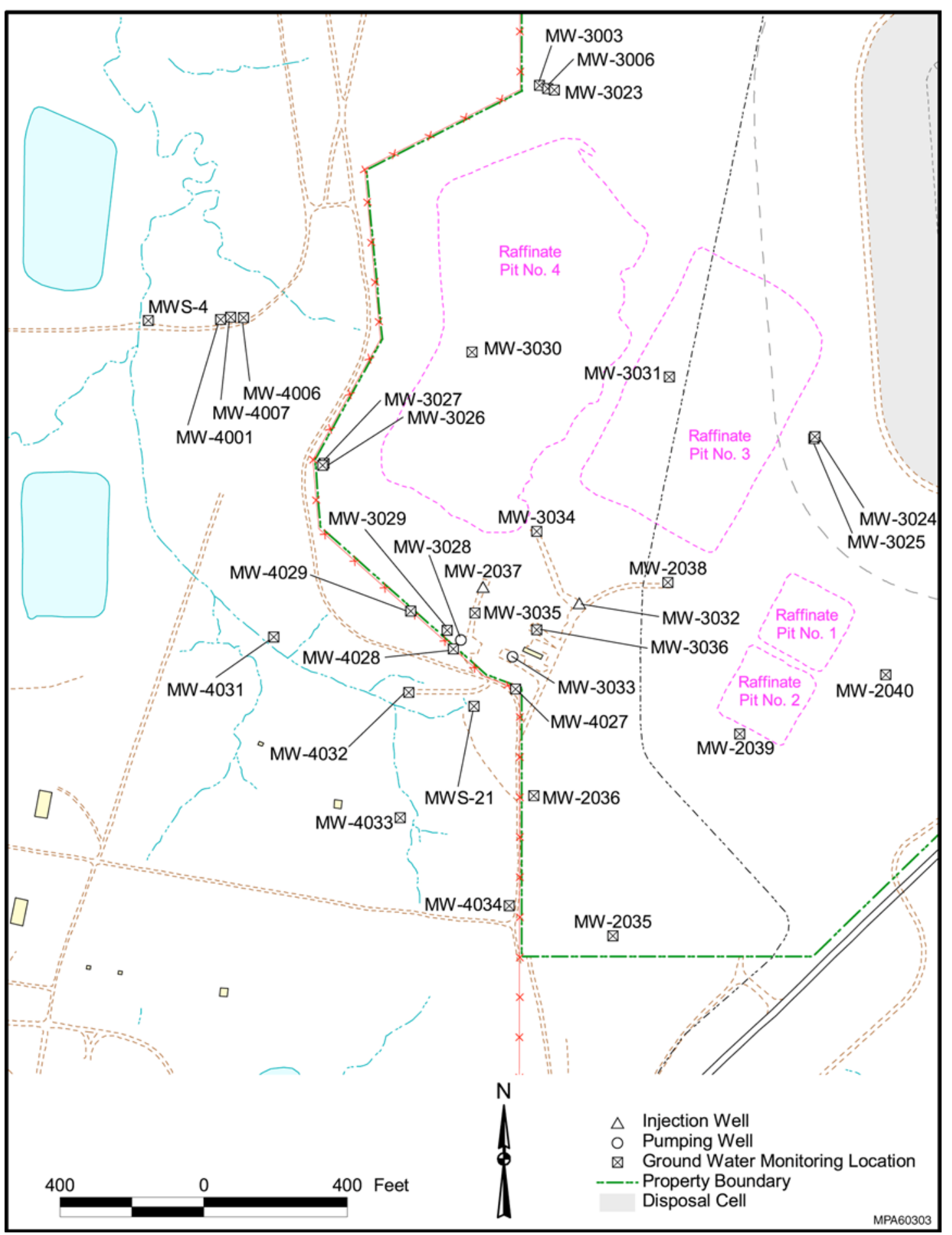

FIGURE 3.1 Locations of Wells for the Additional Field Studies 
5. Introduce artificial recharge at a predetermined rate $(5 \mathrm{gpm})$ and extract groundwater from an angled well to (a) quantify the mass of contaminants removed by using an angled well and artificial recharge and (b) determine if extraction by using an angled well with artificial recharge increases the mass of contaminants removed over that removed by using a vertical well.

6. Introduce artificial recharge at an increased rate $(10 \mathrm{gpm})$ and extract groundwater from an angled well to (a) determine the increase in yield due to increased artificial recharge, (b) quantify the mass of contaminants removed by using increased artificial recharge, and (c) determine if using an angled well with increased artificial recharge increases the mass of contaminants removed.

Each stage was to be performed for 20 days for comparative purposes. Each stage was to start when near-steady-state conditions had been achieved. Near-steady-state conditions in the area of the test were to be determined from water level measurements in the observation wells. The water levels in observation wells MW-3035 and MW-3036 were to be monitored to show evidence of the injection water moving to the pumping well. When the discharge rate in the pumping well needed to be varied to compensate for the artificial recharge, water levels in the observation wells (Figure 3.1) were to be monitored for near-steady-state conditions. The system would be considered near steady state or stable once (1) the shape of the potentiometric surface as determined from the observation wells, (2) the gradients between the injection wells and pumping well, and (3) the discharge rate in the extraction well showed minimal variation for a period of 24 hours. These conditions were to be monitored throughout the 20-day period to demonstrate that near-steady-state conditions were maintained. If it was determined that unanticipated variations had occurred, a study might be extended to maintain a 20 -day nearsteady-state test period. Variations due to barometric pressure changes and recharge due to precipitation would not warrant extension of the study period.

Predetermined rates of 5 and $10 \mathrm{gpm}$ were selected for injection and were to be maintained unless the water level in the injection well rose to levels above an elevation of $187 \mathrm{~m}$ (614 ft) above mean sea level, which corresponds with the historic static water levels in the area of both of those wells. Since removal of the Raffinate Pits, static water levels had lowered by 91 to $122 \mathrm{~cm}$ ( 3 to $4 \mathrm{ft})$ in this area. If water levels exceeded the elevation of $187 \mathrm{~m}(614 \mathrm{ft})$ in either well, the injection rate for that well was to be decreased until the level was achieved. The plan noted that the introduction of water and subsequent mounding of water could result in saturation of higher-elevation fractures, which might lead water away from the pumping well and increase the potential for water to bypass the extraction well, thereby possibly pushing contaminants outside the capture zone of the extraction well. A synopsis of events for each of the stages is presented in Table 3.1 . 
TABLE 3.1 Events during Each Stage of the 2001 Field Studies

\begin{tabular}{|c|c|c|}
\hline Stage & Date & Summary \\
\hline 1 & Mar. 9-Apr. 5 & $\begin{array}{l}\text { Aquifer supports an extraction rate of } 8 \mathrm{gpm} \text { for } 36 \mathrm{~h} \text { in the vertical well MW-3028. } \\
\text { Injection wells are within the area of hydraulic influence of MW-3028. }\end{array}$ \\
\hline 2 & Apr. 6-26 & $\begin{array}{l}\text { By the end of stage } 2 \text {, the extraction rate in MW- } 3028 \text { has declined to } 6 \mathrm{gpm} \text {. } \\
\text { It is determined that the sustainable yield was not determined in Stage } 1 \text {; however, } \\
\text { the rate is less than } 6 \mathrm{gpm} \text {. }\end{array}$ \\
\hline 3 & May 16-June 4 & $\begin{array}{l}\text { Difficulties are encountered in establishing the injection rate of } 5 \mathrm{gpm} \text { in } \mathrm{MW}-3032 \text {. } \\
\text { The threshold for mounding is waived in order to sustain an injection rate of } 5 \mathrm{gpm} \text {. } \\
\text { The extraction rate in MW-3028 is increased to } 9.7 \mathrm{gpm} \text { to compensate for injection } \\
\text { at the two locations. } \\
\text { Localized mounding is observed near the two injection wells. }\end{array}$ \\
\hline 5 & June 27-July 16 & $\begin{array}{l}\text { Stage } 5 \text { activities are performed before Stage } 4 \text { because of difficulties encountered } \\
\text { with water injection at MW- } 3032 \text {. } \\
\text { Pumping is switched to the angled extraction well MW-3033, which initially can } \\
\text { only maintain a pumping rate of only } 3 \mathrm{gpm} \text {. } \\
\text { Thresholds in the injection wells are reestablished because of concerns regarding } \\
\text { mounding of groundwater, and the injection rate in MW-3032 is decreased to } \\
1.3 \mathrm{gpm} \text {. } \\
\text { The extraction rate in MW-3033 is increased to } 3.5 \mathrm{gpm} \text { to compensate for injection } \\
\text { of water at the two locations. }\end{array}$ \\
\hline 6 & Not performed & $\begin{array}{l}\text { Stage } 6 \text { is cancelled because it was evident from Stage } 5 \text { that increasing the rate from } \\
5 \text { to } 10 \mathrm{gpm} \text { in the injection wells would have little influence on the extraction rate in } \\
\mathrm{MW}-3033 \text { and would likely result in significant groundwater mounding. }\end{array}$ \\
\hline 4 & July 24-Aug. 12 & $\begin{array}{l}\text { Pumping is switched back to the vertical extraction well MW-3028. } \\
\text { In order to inject } 10 \text { gpm into MW-3032, a packer is installed and water is injected } \\
\text { under pressure; however, mounding is observed, and the rate is decreased to } 7 \mathrm{gpm} \text {. } \\
\text { The extraction rate in MW-3028 is increased to } 16 \mathrm{gpm} \text { to compensate for injection } \\
\text { at the two locations. }\end{array}$ \\
\hline
\end{tabular}

Water level monitoring was to be performed to determine the effect of the extraction and injection of water on groundwater flow. Baseline groundwater levels had been established before the studies. Water level measurements were to be collected continuously throughout the studies by using pressure transducers programmed to collect measurements at 10-minute intervals. Manual water level measurements were also to be made periodically to evaluate the effects of groundwater extraction and injection of the shallow aquifer in the study area and to verify the readings from the transducers. Groundwater elevation maps were to be constructed to depict the changes in groundwater surface during each stage of the studies. The potentiometric surface data were to be used to evaluate capture zones for each of the stages and changes in flow directions caused by the extraction of groundwater and the injection of potable water during the studies. 
Construction of potentiometric surface maps during the studies indicated that the drawdown caused by pumping did not extend radially from the well. The maximum drawdown was coincident with the orientation of the paleochannel in the study area, a situation that was consistent with previous studies. Bedrock lows at the site have been characterized as being more transmissive than the surrounding bedrock, resulting in greater drawdown within the paleochannel.

Recovery of the shallow aquifer was monitored for several months after the completion of the last stage of active pumping. Five months after groundwater extraction was complete, the water levels in the study area ranged from 9 to $30 \mathrm{~cm}(0.3$ to $1.0 \mathrm{ft})$ below the baseline water levels. The slow recovery supports the hydrogeological conceptual model of a fractured limestone aquifer with limited recharge. The results of the recovery monitoring were consistent with those observed during the previous study in 1998.

Three sampling events were performed in support of these studies. Before the start of the studies, groundwater samples were collected from the pumping wells and nearby monitoring wells to establish baseline water quality conditions. Samples were also collected from Burgermeister Spring (SP-6301), SP-6303, and the Southeast Drainage spring SP-5304. During the studies, samples were collected from the pumping wells daily. Observation and monitoring wells and springs were sampled to monitor the concentrations of nitrate, 2,4-DNT, TCE, and uranium throughout the study period. At the completion of the field studies, samples were collected from the wells and springs to evaluate any long-term changes in contaminant levels due to groundwater removal and to evaluate any potential migration of contaminants due to the injection of water.

Contaminant data were used to calculate the mass of each COC that was removed during each stage of testing and to determine whether any upward or downward trends in contaminant concentrations became apparent as the aquifer responded to pumping and/or injection. Contaminant levels in the wells and springs were monitored to make certain no major changes in contaminant migration occurred.

The mass of each contaminant removed was determined from contaminant levels and from the groundwater volumes extracted each day. A summary of the mass of each contaminant removed during each 20-day stage is presented in Table 3.2.

TABLE 3.2 Contaminant Masses Removed

\begin{tabular}{ccccc}
\hline Stage & Nitrate $(\mathrm{kg})$ & TCE $(\mathrm{g})$ & 2,4-DNT $(\mathrm{g})$ & Uranium $(\mathrm{g})$ \\
\hline & & & & \\
2 & 219 & 228 & 0.14 & 1.09 \\
3 & 216 & 309 & 0.08 & 1.21 \\
5 & 37 & 42 & 0.02 & 0.57 \\
5 & 280 & 268 & 0.14 & 1.30 \\
\hline
\end{tabular}


Stage 2 was established as the baseline stage for comparison with the other stages. The data on the masses of contaminants removed indicate that extraction from the vertical well with injection (Stages 3 and 5) did not significantly increase the masses of nitrate or TCE removed. Changes in the masses of 2,4-DNT or uranium removed could not be evaluated because the total masses removed during each stage were so small. Extraction from the angled well with injection (Stage 4) resulted in reduced masses of contaminants removed, likely because the contaminant concentrations were diluted as a result of the injection of potable uncontaminated water.

\subsubsection{Results of the Field Studies}

The results of the field studies conducted in 2001 indicate that the modifications to the conventional pump and treat systems that were implemented did not increase the masses of contaminants removed over those removed by a conventional vertical well system with no artificial recharge (MK-Ferguson Company and Jacobs Engineering Group 2002). Consequently, the amount of water extracted from the area as a result of artificial recharge would not reduce the remediation time frames for TCE, nitrate, uranium, or nitroaromatic compounds. Another modification, the use of an angled well, likewise failed to produce results comparable to those achieved by the vertical extraction well. These results reflect the difficulty involved in siting productive wells in the complex geology of the site.

The hydrogeologic data obtained from the 2001 field studies were consistent with the data collected during a previous study performed in 1998. The results from both of these field studies support the conceptual model, which assumes that the sustainable yields are low and recharge of the aquifer is very slow, as indicated by the recovery of the monitoring wells. Continuous pumping would result in localized dewatering in the vicinity of the extraction well. Cycles of pumping could be performed, but because of the slow recharge of the aquifer, periods between active pumping would be long.

The sustainable yield of the shallow aquifer in this area was not quantified during these studies, but it is not greater than $3 \mathrm{gpm}$. On the basis of the performance of MW-3028 and MW-3033, several general conclusions can be made:

- Extraction rates greater than $20 \mathrm{gpm}$ exceed the capability of the aquifer to release water. Rapid dewatering was observed during Stage 1 when the water table was initially lowered at this rate.

- An extraction rate of $10 \mathrm{gpm}$ resulted in a more uniform dewatering of the aquifer throughout the study area.

- The extraction rate in MW-3028 was approximately equal to the combined injection rate of the two wells during Stage 3 (extraction $=9.7 \mathrm{gpm}$, injection $=8.5 \mathrm{gpm})$ and Stage $4($ extraction $=16 \mathrm{gpm}$, injection $=17 \mathrm{gpm})$.

The field studies demonstrated the difficulty of using artificial recharge effectively in a heterogeneous, fractured medium. Poor hydraulic connections between locations were indicated 
by the (1) mounding associated with the injection site; (2) dissimilar behavior of the two injection wells in close proximity $(<300 \mathrm{ft}$ ) to each other; (3) incomplete capture of injection water, even though the injection wells were within the hydraulic capture of the extraction wells; and (4) limited increases in extraction rates from the wells during the injection stages.

After the start of injection, mobilization of contaminants was demonstrated by increasing concentrations of nitrate in downgradient monitoring wells, such as MW-3003, MW-3030, and MW-4001 (Figure 3.1), as well as in springs SP-6301 and SP-6303. An upward trend was observed throughout the studies; however, the contaminant concentrations in these springs did not approach historical highs.

The distribution of the contaminants did not change as a result of the field studies, except for the significant dilution that occurred in the vicinity of the injection wells. The majority of the wells returned to baseline concentrations or were showing increasing trends at the end of the monitoring period, which could be attributed to several mechanisms. One mechanism might have been the slow transport of upgradient contaminated groundwater into the study area because of the low hydraulic gradient across the Chemical Plant area. Another mechanism might have been the diffusion of contaminants from poorly connected or dead-end fractures and solution features into the more transmissive portions of the aquifer (i.e., paleochannels). Either scenario indicates that the majority of the contaminated groundwater that was removed came from the more transmissive, interconnected, secondary porosity features (likely paleochannels). This conclusion indicates that extracting the water from the more transmissive portions of the shallow aquifer would remove the groundwater only in this small discrete area, and that slower groundwater movement (recharge) from the less conductive portions of the aquifer would dictate much longer total remediation time frames.

\subsubsection{Evaluation of the Groundwater Removal Technologies for Application at the Chemical Plant Area}

\subsubsection{Effectiveness}

The results presented above indicate that the groundwater removal technologies (using both conventional and enhanced methods) would not provide additional protection to human health and the environment for either the short term or the long term. The masses of contaminants removed during the field studies were very small and would not constitute an effective remedial approach. Groundwater removal technologies were demonstrated to be limited in their capacity to remediate the groundwater because their influence was small and they could not effectively draw contaminated groundwater from the more widespread areas of low transmissivity. The length of time needed for these technologies to achieve ARARs is uncertain but would probably be comparable to the time frame predicted for natural attenuation processes (i.e., approximately 100 years). The ability of these technologies to reduce toxicity, mobility, or volume was not demonstrated by the field tests. 
The groundwater that was extracted during the study came from more discrete zones made up of more fractured and more transmissive bedrock, but the larger areas of less fractured and less transmissive bedrock control recharge. The extraction methods did not effectively remove groundwater from these larger areas of less fractured and less transmissive bedrock. Also, the groundwater levels in the aquifer did not return to near static levels until almost a year after the field studies. Given these conditions, the use of continuous or cycling pumping scenarios would not be effective because the limits from recharge would result in long remediation time frames, similar to those predicted for natural attenuation (i.e., approximately 100 years). Continuous pumping from the extraction wells might be maintained through the use of artificial recharge to the shallow aquifer. The drawbacks to this method, which were demonstrated during the field studies, were mounding of groundwater, poor hydraulic connections between some locations and the extraction wells, and incomplete capture of the injected water.

\subsubsection{Implementability}

The development of a design for a groundwater removal system would be limited by the site aquifer characteristics (as demonstrated by the limitations experienced under the pump test studies in both 1998 and 2001). The most optimistic approach would be to use artificial recharge in order to sustain beneficial extraction rates from the pumping wells. Even in the more transmissive portions of the aquifer (similar to where the field studies were performed), continuous or cyclic pumping could likely not be sustained because of the limited recharge to these areas from the less fractured and transmissive portions of the aquifer.

\subsubsection{Cost}

The cost for implementing an effective groundwater removal system is difficult to estimate because such a design could not be developed. However, to provide the costs needed for comparing this technology with others being considered, estimates were developed by using best engineering judgment and by incorporating information from the field tests. The estimates assume that artificial recharge would be utilized. The estimates indicate that the capital cost for groundwater removal (and treatment) would be at least $\$ 5$ million and the annual cost would be at least $\$ 2$ million. About half of the capital cost would be for the construction of a treatment facility.

Table 3.3 shows the items that could be included when implementing a groundwater removal technology at the Weldon Spring Site. The treatment technology is not reevaluated in this report because conventional treatment technologies could be used if the groundwater was able to be extracted. The cost estimates shown in Table 3.3 do, however, include the construction of a treatment plant for completeness.

The groundwater removal technology would not be cost effective because it would have limited application and would not be any more effective in reducing site risks than passive approaches would be. 
TABLE 3.3 Representative Cost Estimates for Groundwater Removala

\begin{tabular}{|c|c|}
\hline Item & Cost $(\$)$ \\
\hline \multicolumn{2}{|l|}{ Capital costs } \\
\hline Installation of extraction and injection wells & $1,520,000$ \\
\hline Pumps $(28 \times \$ 3,500)$ & 98,000 \\
\hline $\begin{array}{l}\text { Piping (high-density polyethylene or HDPE) } \\
(10,000 \mathrm{ft} \times \$ 38 / \mathrm{ft} \text {, including material and labor) }\end{array}$ & 380,000 \\
\hline \multicolumn{2}{|l|}{ Treatment facility } \\
\hline \multicolumn{2}{|l|}{ GAC and ion exchange } \\
\hline \multicolumn{2}{|l|}{ Emergency storage of water } \\
\hline \multicolumn{2}{|l|}{ Site preparation } \\
\hline \multicolumn{2}{|l|}{ Connection to discharge (if necessary) } \\
\hline \multicolumn{2}{|l|}{ Connection to injection points } \\
\hline Total for treatment facility & $2,500,000$ \\
\hline Engineering and oversight (15\%) & 670,000 \\
\hline Total capital costs & $5,170,000$ \\
\hline \multicolumn{2}{|l|}{ Operation and maintenance costs } \\
\hline System operations (assumed twice the GWOU field study costs) & 908,000 \\
\hline \multicolumn{2}{|l|}{ General expenses } \\
\hline \multicolumn{2}{|l|}{ Chemicals } \\
\hline \multicolumn{2}{|l|}{ Supplies } \\
\hline \multicolumn{2}{|l|}{ Analytical for discharge replacement pumps } \\
\hline Total for general expenses & 806,000 \\
\hline Disposal/material to Envirosafe & 5,000 \\
\hline $\begin{array}{l}\text { Groundwater monitoring (assumed to be } 60 \% \text { of MNA sampling } \\
\text { preliminary design shown in Section 5) }\end{array}$ & 91,500 \\
\hline Routine well maintenance & 50,000 \\
\hline Oversight $5 \%$ & 93,000 \\
\hline Contingency $10 \%$ & 195,000 \\
\hline Total operation and maintenance costs & $2,150,000$ \\
\hline
\end{tabular}

a The estimates shown are for a preliminary groundwater removal system and for costing purposes only. Assumptions regarding the installation of about 28 extraction wells and 38 injection wells were based on a reasonable radius of influence gleaned from the field study.

\subsection{IN-SITU CHEMICAL OXIDATION (ICO)}

ICO involves the introduction (via injection wells) of an oxidant (chemical solution) into the groundwater to oxidize TCE. For the pilot-phase ICO, a permanganate solution (i.e., sodium permanganate) was used as the oxidant. ICO was selected as the remedial action in the IROD (DOE 2000) because, of all the technologies evaluated, it offered the best potential for quickly reducing TCE levels, and it would be cost effective. However, it was also recognized that uncertainties associated with the complex hydrogeology of the site would likely affect the 
effectiveness and implementability of the ICO process. Moreover, ICO addresses only TCE and not the other COCs.

To implement the IROD remedial action, DOE procured bench-scale tests by several vendors. The objectives were to demonstrate the effectiveness of ICO in treating TCE at the site and to evaluate all of the ICO processes. On the basis of the results of these initial tests, proposals were solicited to conduct the remedial action stipulated in the IROD. However, the development of the design to achieve full treatment of TCE throughout the plume was not possible at the outset because of uncertainties associated with the hydrogeology of the site that influenced design elements such as the actual spacing of the injection wells, the zone of influence of these wells, and the amount of oxidants that needed to be injected to reduce the TCE level. A lack of responsive bids from vendors on the full-scale scope provided further indication of the difficulty in developing this design. Consequently, a phased approach was taken so that pilot-phase activities could be performed before any decisions regarding full implementation were made.

\subsubsection{Description of Pilot-Phase ICO}

Pilot-phase ICO was performed in April and May 2002 to evaluate the effectiveness of the ICO process under actual field conditions and to assess the feasibility of implementing a fullscale system. The pilot-phase activities were performed at two locations, representing the upper and lower limits of the hydraulic condition in the bedrock aquifer within the area of higher TCE concentrations. Groundwater monitoring continued until July 2002. A detailed discussion of the field activities is presented in the pilot-scale testing completion report on in-situ chemical oxidation of TCE in groundwater (ATC Associates, Inc. 2002).

The conceptual approach used in the pilot phase was to begin with relatively small volumes of sodium permanganate and increase them under highly controlled conditions, while monitoring over the course of the two injection phases to determine an effective radius of influence and volume of permanganate. The approach was intended to provide the data necessary for full-scale project design and to demonstrate the effectiveness of ICO at the site while minimizing the risk of overdosing the aquifer. Overdosing would mean that more permanganate was injected than required to achieve the cleanup objectives. This would result in larger impacts from secondary effects on the aquifer, such as elevated metal concentrations, which could be toxic or could further inhibit groundwater flow.

Two injection wells and six monitoring wells were installed for the pilot-phase ICO (Figure 3.2). All of these wells were installed through the full thickness of the weathered portion of the Burlington-Keokuk Limestone. Packer tests and borehole geophysical tests were performed to evaluate the hydraulic conductivity and groundwater flow in each of the injection wells. The hydraulic conductivities in injection wells LIW1 and HIW1 were $4 \times 10^{-4} \mathrm{~cm} / \mathrm{s}$ and $3 \times 10^{-3} \mathrm{~cm} / \mathrm{s}$, respectively. The value for HIW1 was considered a minimum value and was likely much higher. 


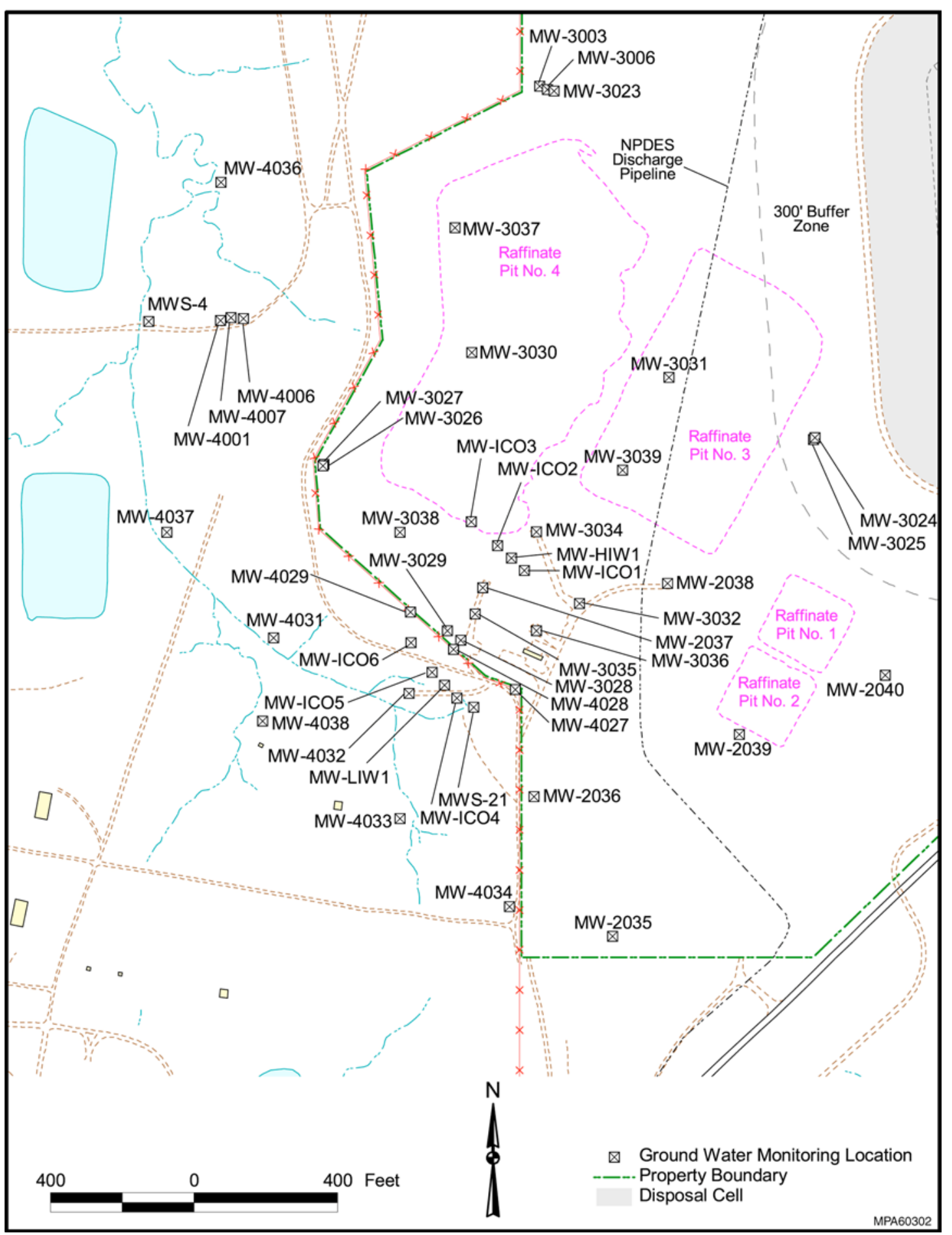

FIGURE 3.2 Locations of Wells for Pilot-Phase In-Situ Chemical Oxidation 
During the first stage of the pilot-phase ICO, only the minimum calculated amount of sodium permanganate that might result in efficient distribution though the aquifer was injected. Sampling of nearby monitoring wells was performed during the treatment to evaluate the distribution of permanganate during and after injection. Results indicated that wells MW-1 through MW-3 and MW-3030 in the high-K area and MW-4, MW-5, MW-4028, and MW-4032 in the low-K area were potentially within the effective radius of influence on the basis of oxidation reduction potential (ORP) measurements. Sodium permanganate was observed in MW-2 three days after injection and in MW-3034 10 days after injection; however, permanganate was not observed in any of the monitoring wells near LIW1.

The area of sodium permanganate impact was larger in the vicinity of HIW1 than LIW1 and was likely a result of the higher hydraulic conductivity in the vicinity of HIW1 and the presence of the nearby paleochannel, which acts as a conduit for groundwater movement in excess of the anticipated gradient for the area. The area bounded by the wells that showed an impact from sodium permanganate was irregularly shaped, indicating that homogeneous dispersion in each direction from the injection well did not occur. Dispersion of the sodium permanganate in groundwater was most likely affected by the hydrogeology of the area, with the permanganate following the preferential groundwater gradient toward the paleochannel.

On the basis of the results from the first stage of injection, the target injection volumes were revised for the second stage. The volume of sodium permanganate solution injected at LIW1 was increased $600 \%$, and it was decreased $25 \%$ at HIW1. Sampling of nearby monitoring wells was again performed to evaluate the distribution of permanganate during and after injection. Results indicated that ICO-1 through ICO-3, MW-3032, MW-3034, and MW-3030 in the high-K area and ICO-4 through ICO-6, MW-4028, MW-4032, and MW-S021 in the low-K area were potentially within the effective radius of influence. The increase in ORP at MW-3030 supported the conclusion that the injected sodium permanganate solution preferentially moved toward the paleochannel at a faster rate than anticipated on the basis of general groundwater gradients present in the study area. Sodium permanganate was detected in MW-1 in the high-K area. In the low-K area, sodium permanganate was observed in MW-4 and MW-5 two days after injection and in MW-4028 and MW-4032 three days after injection. Again, preferential dispersion of the permanganate was observed in the direction of the paleochannel in both the high-K and low-K areas.

Groundwater quality sampling was performed before, during, and after the pilot-phase ICO. Baseline sampling was performed for comparative purposes to evaluate TCE destruction and possible impacts to the groundwater quality from metals, which are typical impurities in a permanganate solution. Sampling was performed during and after the pilot-phase ICO to evaluate the amount of TCE destruction, persistence of metals in the groundwater, and rebound to TCE concentrations at locations where destruction had previously occurred. Samples were collected 10 days after each injection and then 30 and 60 days after the second injection. Routine monitoring of TCE in this area is still performed, and subsequent data are available.

TCE destruction was observed in ICO-2 and MW-3034 in the high-K area 10 days after the first injection. No TCE destruction was observed in the low-K area after the first injection. 
After the second injection, TCE destruction was observed in ICO-1, ICO-2, and MW-3034 in the high-K area and in ICO-4, ICO-5, and MW-4028 in the low-K area 10 days after injection. The results of the first injection demonstrated that TCE could be oxidized to nondetectable concentrations by sodium permanganate. The key factor for successful TCE destruction is effective distribution of TCE in the aquifer. Where sodium permanganate was observed during or immediately after injection, the results indicated large reductions.

Sixty days after the second injection, sodium permanganate was detected in ICO-2 and MW-3034 in the high-K area and in MW-4028 in the low-K area. TCE destruction was still reported for these wells (Table 3.4). TCE concentrations increased to near baseline levels in those wells where permanganate had been previously present, but it was not observed during this sampling event. Monitoring data collected in March 2003 (1 year after injection) indicates that TCE levels rebounded to near baseline concentrations in MW-3034.

Chromium and manganese concentrations increased proportionally to sodium permanganate concentrations over the course of injection and monitoring. Manganese was detected in the undiluted reagent and the diluted permanganate solution. During the pilot-phase ICO, increased manganese concentrations were not detected in wells in which sodium permanganate was not observed (ATC Associates, Inc. 2002). An increase in manganese

TABLE 3.4 TCE Concentrations for Pilot-Phase In-Situ Chemical Oxidation

\begin{tabular}{|c|c|c|c|c|c|c|}
\hline \multirow[b]{2}{*}{ Location } & \multicolumn{6}{|c|}{$\mathrm{TCE}\left(\int \mathrm{g} / \mathrm{L}\right)$} \\
\hline & Baseline & $\begin{array}{c}\text { First } \\
\text { Injection }\end{array}$ & $\begin{array}{c}\text { Second } \\
\text { Injection }\end{array}$ & $\begin{array}{c}30 \text { Days } \\
\text { Later }\end{array}$ & $\begin{array}{c}60 \text { Days } \\
\text { Later }\end{array}$ & $\begin{array}{l}1 \text { Year } \\
\text { Later }\end{array}$ \\
\hline \multicolumn{7}{|l|}{ High-K area } \\
\hline ICO-1 & 230 & 210 & 23 & 100 & 180 & $\mathrm{NS}^{\mathrm{a}}$ \\
\hline ICO-2 & 230 & $<1$ & $<1$ & $<1$ & $<1$ & NS \\
\hline ICO-3 & 140 & 180 & 200 & 210 & 210 & NS \\
\hline MW-2037 & 31 & 34 & 34 & 40 & 42 & 105 \\
\hline MW-3032 & $<1$ & $<1$ & $<1$ & $<1$ & $<1$ & NS \\
\hline MW-3034 & 470 & $<1$ & $<1$ & $<1$ & $<1$ & 203 \\
\hline \multicolumn{7}{|l|}{ Low-K area } \\
\hline ICO-4 & 110 & 100 & 1.5 & 93 & 110 & NS \\
\hline ICO-5 & 170 & 160 & 27 & 140 & 99 & NS \\
\hline ICO-6 & 380 & 300 & 400 & 490 & 440 & NS \\
\hline MW-4028 & 210 & 180 & 5.5 & $<1$ & $<1$ & $<1$ \\
\hline MW-4032 & 91 & 92 & 65 & 86 & 71 & 63 \\
\hline MW-S021 & 63 & 76 & 76 & 67 & 75 & 74 \\
\hline
\end{tabular}

a $\mathrm{NS}=$ not sampled.

Source: ATC Associates, Inc. (2002). 
concentrations over baseline results was reported in wells ICO-2 and MW-3034 after the first injection. The increase in manganese concentrations was indicative of the presence of sodium permanganate. An increase in manganese concentrations over previous results was reported for wells ICO-1, ICO-2, and MW-3034 in the high-K area and ICO-4, ICO-5, and MW-4028 in the low-K area.

Increases in concentrations of chromium, which is present in commercially supplied sodium permanganate, were also directly proportional to increases in permanganate concentrations. Chromium concentrations increased in ICO-2 and MW-3034 after the first injection (Table 3.5). Elevated concentrations were detected in ICO-1, ICO-2, and MW-3034 in the high-K area and in ICO-4, ICO-5, and MW-4028 in the low-K area after the second injection. Chromium concentrations were elevated above the groundwater standard in ICO-2, ICO-4, ICO-5, MW-3034, and MW-4028 during the 60-day sampling event. Additional data to evaluate the persistence of chromium in the groundwater are being collected.

\subsubsection{Results of Pilot-Phase ICO}

The pilot-phase ICO temporarily reduced TCE concentrations in the area of influence. However, data collected from some of these locations in 2003 indicated that the TCE concentrations reappeared at the same levels as those that existed before implementation. The

TABLE 3.5 Chromium Concentrations for Pilot-Phase In-Situ Chemical Oxidation

\begin{tabular}{|c|c|c|c|c|c|}
\hline \multirow[b]{2}{*}{ Location } & \multicolumn{5}{|c|}{ Chromium $(\lceil\mathrm{g} / \mathrm{L})$} \\
\hline & Baseline & $\begin{array}{c}\text { First } \\
\text { Injection }\end{array}$ & $\begin{array}{c}\text { Second } \\
\text { Injection }\end{array}$ & $\begin{array}{c}30 \text { Days } \\
\text { Later }\end{array}$ & $\begin{array}{c}60 \text { Days } \\
\text { Later }\end{array}$ \\
\hline \multicolumn{6}{|l|}{ High-K area } \\
\hline ICO-1 & $<10$ & $<10$ & 28 & 29 & $<10$ \\
\hline ICO-2 & $<10$ & 51 & 102 & 118 & 87 \\
\hline ICO-3 & $<10$ & $<10$ & $<10$ & $<10$ & $<10$ \\
\hline MW-2037 & $<10$ & $<10$ & $<10$ & $<10$ & $<10$ \\
\hline MW-3032 & $<10$ & $<10$ & $<10$ & $<10$ & $<10$ \\
\hline MW-3034 & $<10$ & 17 & 125 & 152 & 145 \\
\hline \multicolumn{6}{|l|}{ Low-K area } \\
\hline ICO-4 & $<10$ & $<10$ & 12 & $<10$ & 24 \\
\hline ICO-5 & $<10$ & $<10$ & 13 & $<10$ & 11 \\
\hline ICO-6 & $<10$ & $<10$ & $<10$ & $<10$ & $<10$ \\
\hline MW-4028 & $<10$ & $<10$ & 39 & 102 & 135 \\
\hline MW-4032 & $<10$ & $<10$ & $<10$ & $<10$ & $<10$ \\
\hline MW-S021 & $<10$ & $<10$ & $<10$ & $<10$ & $<10$ \\
\hline
\end{tabular}

Source: ATC Associates, Inc. (2002). 
sodium permanganate solution was distributed to a distance of about $30 \mathrm{~m}(100 \mathrm{ft})$ from the injection point, with the dispersion of the sodium permanganate favoring a downgradient direction toward the paleochannel features of the site. Uniform distribution of the injected chemicals was not achieved. The pilot-phase ICO also indicated that the volume of sodium permanganate solution that would be required to achieve a radius of influence greater than $30 \mathrm{~m}$ (100 ft) could average 20,000 gal at each injection point. This volume is 20 times greater than the volume estimated on the basis of results from bench-scale testing and 5 times greater than the volume used during the first injection of the pilot-phase ICO.

In addition, increased chromium, mercury, silver, and manganese concentrations were observed in areas where sodium permanganate appeared. Although the metal concentrations are expected to decrease in proportion to the disappearance of the sodium permanganate solution injected, insufficient data are available to verify this expectation. Sodium permanganate was still present at some locations 1 year after the completion of the pilot-phase ICO. Sodium permanganate treatment did not affect uranium or nitrate concentrations at the site.

The results of the pilot-phase ICO could not be directly applied to the whole TCE area because of the nonuniform, heterogeneous nature of the site hydrogeology. The study was designed to perform the field tests at two locations within the impacted area: the first location was at the least conductive area with high TCE concentrations, and the second location was at the most conductive area with high TCE concentrations. However, this objective may not have been achieved during implementation, since other areas with lower conductivities and with TCE concentrations that exceed the MCL are known to be present. Consequently, uncertainties associated with defining the zone of influence of the injection points and with defining the volume of oxidants needed to achieve the required reduction of TCE across the impacted area would still have to be addressed if a full-scale remediation effort were being designed. It was envisioned in the IROD that two sets of wells and two injections would achieve the MCL. (These specifications were based on current knowledge about the innovative nature of the ICO technology at that time.) However, preliminary remedial designs based on the results of the pilotphase work indicated that at least 20 times as many injection wells would be needed, and, therefore, 20 times as much volume of the oxidant would need to be injected for a full-scale implementation. These estimates address the amounts needed at the initial phase of the implementation; additional injection wells and a greater volume of oxidants might be needed to attain the MCL. The limitations imposed by site hydrogeology on the design for full-scale implementation, coupled with concerns about the potentially large increase in metal concentrations in groundwater that could result from the large volume of the chemical that was injected and from the persistence of the chemical in the aquifer, were the primary factors that contributed to the overall decision not to go forward with full-scale implementation of ICO. 


\subsubsection{Evaluation of the ICO Technology for Application at the Chemical Plant Area}

\subsubsection{Effectiveness}

The results of the pilot-phase ICO conducted in 2002 indicate that the ICO technology could provide protection of human health and the environment for at least the short term on a localized basis, since the technology was demonstrated to have reduced TCE concentrations to the MCL within the localized area of influence soon after its implementation. Its long-term potential is uncertain, however, since recent data indicate a reappearance of TCE concentrations at monitoring wells where they had been reduced via ICO to nondetectable levels. This reappearance is likely due to recontamination from adjacent contaminated portions of the groundwater that were not treated or were not in the area of influence of the pilot-phase ICO. The potential for full-scale application of ICO to treat the entire TCE plume is also uncertain, since the effective distribution of sodium permanganate could not be achieved because of the highly varying hydraulic conductivities.

\subsubsection{Implementability}

The pilot-phase ICO indicated that it is technically feasible to implement this technology on a localized basis. However, full-scale treatment could not be designed with certainty to reduce TCE in the entire plume to the MCL.

\subsubsection{Cost}

The cost for the pilot-phase ICO was approximately $\$ 1$ million. A preliminary estimate for a larger-scale effort intended to treat the entire plume indicates that the capital cost would be greater than $\$ 9$ million. However, the ability of ICO to reduce TCE concentrations to the MCL and the cost of additional treatment to address rebound are uncertain; these factors could increase the cost to a much larger amount. Uncertainties that would need to be taken into account make it difficult to provide more definitive estimates. ICO could be cost effective on a small scale, such as the scale implemented for the IROD in 2002.

\subsection{MONITORED NATURAL ATTENUATION}

Monitored natural attenuation (MNA), as defined by the EPA, "refers to the reliance on natural attenuation processes (within the context of a carefully controlled and monitored site cleanup approach) to achieve site-specific remediation objectives within a time frame that is reasonable compared to that offered by other more active methods" (EPA 1999). Natural attenuation processes include a variety of physical, chemical, and biological processes that act without human intervention to reduce the mass, toxicity, mobility, volume, or concentration of contaminants in soil or groundwater. Relevant physical processes include dilution, dispersion, and sorption; chemical processes include stabilization, destruction, and volatilization; and 
biological processes include stabilization or degradation by plants or microorganisms. Cleanup at a contaminated site when MNA is used (as when other remedies are used) is not complete until all cleanup objectives have been met. Monitoring is required to ensure that natural attenuation is occurring, to watch plume migration, and to identify any transformation products, as applicable, in order to protect potential receptors.

For the Chemical Plant area, the primary processes affecting all COCs in groundwater are dilution and dispersion. Source removals conducted per the Chemical Plant ROD (DOE 1993) are expected to prevent further groundwater contamination, and fresh rainwater and runoff that enter the aquifer over time will serve to dilute remaining groundwater contaminants. In some places, contaminant transport will occur slowly. In other areas, particularly those associated with the karst features, transport will be faster, with potentially large dilution.

On the basis of site geochemical conditions, biological degradation of TCE and the nitroaromatic compounds is unlikely to be a major mechanism of attentuation. Although 1,2-dichloroethylene (1,2-DCE), which is an anaerobic degradation product of TCE, has been detected in a few wells, this 1,2-DCE could be attributable to the original source of contamination. Low levels of DCE have been detected in a few wells where TCE has not been observed. Data from the site are not favorable for denitrification of nitrate or immobilization of uranium, both of which require reducing conditions (DOE 1999a). In addition to dilution and dispersion, uranium is also significantly attenuated by sorption in the overburden.

To support the evaluation for application of MNA at the Chemical Plant area, estimates for how much time it takes for natural processes to reduce contaminant concentrations were performed. These time estimates are needed to determine if MNA could achieve remediation objectives within a time frame considered reasonable. These estimates are discussed further below.

\subsubsection{Estimates of Predictive Times for MNA}

Calculations were performed to estimate predictive times (the number of years) when natural attenuation processes would likely reduce concentrations of the COCs to levels equal to or below the chemical-specific ARARs and RBCs. These calculations assumed that natural attenuation processes at the Chemical Plant area involve dilution and dispersion. These calculations were initially presented in the Supplemental FS (DOE 1999a). However, to incorporate observations from the field studies completed in 2001 (MK-Ferguson Company and Jacobs Engineering Group 2002) and to incorporate more representative values for several of the input parameters, these calculations are reevaluated here in this report.

The following input parameters were revised from those used in the Supplemental FS. (1) For hydraulic conductivity, the upper 95\% limit of the arithmetic mean of the hydraulic conductivities within a given plume contour was used. This approach was taken to account for the highly permeable regions associated with paleochannel features at the site. (2) For hydraulic gradient, a revised value to account for the variability along the groundwater flow path was used. (3) For effective porosity, a lower value than that used in the Supplemental FS was used to be 
more representative of site conditions. (4) For contaminant concentrations, current concentrations averaged over the plume area were used. (5) More representative distribution coefficients $\left(\mathrm{K}_{\mathrm{d}}\right.$ 's) were incorporated. The $\mathrm{K}_{\mathrm{d}}$ 's used in the Supplemental FS calculations were those identified for soil matrices, and they are not considered to be completely representative for the aquifer matrix being evaluated.

Table 3.6 presents a summary of the input parameters and the results obtained from the revised calculations. Equations used for the calculations are discussed below. The time frames presented in Table 3.6 are shorter than those presented in the Supplemental FS. The decrease in the number of years primarily resulted from the use of higher hydraulic conductivities, lower distribution coefficients, and generally lower contaminant concentrations (based on more current data) for the revised calculations.

Under the processes of dilution and dispersion, dissolved contaminants in the groundwater beneath the Chemical Plant area would primarily move in the direction of natural groundwater flow. In general, this flow would be to the west and northwest for groundwater north of the groundwater divide. The total flux (volume of contaminated water/time) of contaminated water out of a plume can be defined as follows:

$$
\text { Flux }=\frac{V_{d}}{\phi} A_{t} \varphi=K \nabla h t W
$$

where

$$
\begin{aligned}
V_{d} & =\text { Darcy's groundwater velocity given by } K \Lambda h \text { (Freeze and Cherry 1979), } \\
\mathrm{N} & =\text { effective porosity of the porous medium, } \\
A_{t} & =\text { total area of the aquifer perpendicular to the direction of groundwater flow, } \\
K & =\text { hydraulic conductivity of the porous medium material, } \\
\Lambda h & =\text { hydraulic gradient present, } \\
t & =\text { thickness of the aquifer, and } \\
W & =\text { width of the contaminated zone. }
\end{aligned}
$$

When degradation processes are ignored, the number of pore volumes for contaminated water that must be discharged from a contaminated plume in order to meet ARARs or RBCs was defined as follows (Cohen et al. 1997):

$$
\text { Number of pore volumes }=\mathrm{R} \ln \left(\frac{C_{0}}{C_{W}}\right),
$$

where $R$ is the retardation coefficient for the COC given by 
TABLE 3.6 Revised Predictive Monitored Natural Attenuation Cleanup Times Based on the Flushing Model ${ }^{\mathrm{a}}$

\begin{tabular}{|c|c|c|c|c|c|c|c|c|c|c|c|}
\hline Contaminant & Contour & Wells Included & $\begin{array}{c}\mathrm{K}_{\mathrm{d}}^{\mathrm{b}} \\
(\mathrm{mL} / \mathrm{g}) \\
\end{array}$ & $\mathrm{R}$ & $\begin{array}{c}\mathrm{K}^{\mathrm{c}} \\
(\mathrm{UL} 95) \\
(\mathrm{cm} / \mathrm{s}) \\
\end{array}$ & $\begin{array}{l}\text { Actual } \\
\text { GW } \\
\text { Velocity } \\
\text { (ft/yr) }\end{array}$ & $\begin{array}{c}\mathrm{L} \\
(\mathrm{ft}) \\
\end{array}$ & $\Lambda \mathrm{h}$ & $\begin{array}{l}\text { Initial } \\
\text { Conc. } \\
\text { (avg.) }\end{array}$ & $\begin{array}{l}\text { Regulatory } \\
\text { Standard or } \\
\text { RBC }^{\text {RB }}\end{array}$ & $\begin{array}{l}\text { Time } \\
(\mathrm{yr})\end{array}$ \\
\hline \multirow[t]{2}{*}{ Uranium } & Contour 1 & 3030 & 0.4 & 5.5 & 0.0012 & 103.3 & 1,050 & 0.0125 & $54 \mathrm{pCi} / \mathrm{L}$ & $20 \mathrm{pCi} / \mathrm{L}$ & 56 \\
\hline & Contour 2 & 3025 & 0.4 & 5.5 & 0.003 & 258.7 & 460 & 0.0125 & $29 \mathrm{pCi} / \mathrm{L}$ & $20 \mathrm{pCi} / \mathrm{L}$ & 4 \\
\hline TCE & Contour 1 & $\begin{array}{l}\text { 4006, 4001, 3030, 3025, 4037, } \\
3039,3034,2037,2038,4029, \\
3035,4031,3036,3029,3028, \\
4028,3033,4027,4032, \text { MWS } 21, \\
4038,3032\end{array}$ & 0.3 & 4.4 & 0.00411 & 141.7 & 1,300 & 0.005 & $61 \mu \mathrm{g} / \mathrm{L}$ & $5 \mu \mathrm{g} / \mathrm{L}$ & 101 \\
\hline \multirow[t]{3}{*}{ Nitrate } & Contour 1 & & & & & & & & & & \\
\hline & Area 1 & $\begin{array}{l}4036,3037,4006,4001,3030, \\
3031,3027,3026,3039,3025, \\
4027,3038,3034,2037,2038, \\
4029,3035,3032,3028,3029, \\
3036,4031,4028,3033,4038,4032\end{array}$ & 0 & 1 & 0.00315 & 130.4 & & 0.006 & $198 \mathrm{mg} / \mathrm{L}$ & $10 \mathrm{mg} / \mathrm{L}$ & 63 \\
\hline & Area 2 & $\begin{array}{l}4013,2001,2005,4011,2021 \\
2002,2047,2003,3003,3023\end{array}$ & 0 & 1 & 0.00173 & 238.7 & 2,350 & 0.02 & $173 \mathrm{mg} / \mathrm{L}$ & $10 \mathrm{mg} / \mathrm{L}$ & 28 \\
\hline \multirow[t]{3}{*}{ 2,4-DNT } & Contour 1 & $\begin{array}{l}3038,2037,4029,3035,3029 \\
3028,4028,3033,4032, \text { MWS } 21, \\
4033,4006,4001,3030,3039 \\
3034,2038\end{array}$ & 0.09 & 2.0 & 0.001 & 55.2 & 1,600 & 0.008 & $0.43 \mu \mathrm{g} / \mathrm{L}$ & $0.11 \mu \mathrm{g} / \mathrm{L}$ & 79 \\
\hline & Contour 2 & 2047,2046 & 0.09 & 2.0 & 0.00104 & 43.0 & 400 & 0.006 & $0.18 \mu \mathrm{g} / \mathrm{L}$ & $0.11 \mu \mathrm{g} / \mathrm{L}$ & 9 \\
\hline & Contour 3 & $\begin{array}{l}2052,2006,2053,2054,2013, \\
2012,2049,2050,2033,4030,2014\end{array}$ & 0.09 & 2.0 & 0.00352 & 267.1 & 1,400 & 0.011 & $114 \mu \mathrm{g} / \mathrm{L}$ & $0.11 \mu \mathrm{g} / \mathrm{L}$ & 73 \\
\hline 1,3-DNB & Contour 1 & 2012 & 0 & 1.0 & 0.001 & 76 & 500 & 0.011 & $1.7 \mu \mathrm{g} / \mathrm{L}^{\mathrm{e}}$ & $1.0 \mu \mathrm{g} / \mathrm{L}$ & 4 \\
\hline NB & Contour 1 & 2012 & 0 & 1.0 & 0.001 & 76 & 500 & 0.011 & $69 \mu \mathrm{g} / \mathrm{L}^{\mathrm{e}}$ & $17 \mu \mathrm{g} / \mathrm{L}$ & 9 \\
\hline
\end{tabular}


TABLE 3.6 (Cont.)

\begin{tabular}{|c|c|c|c|c|c|c|c|c|c|c|c|}
\hline Contaminant & Contour & Wells Included & $\begin{array}{c}\mathrm{K}_{\mathrm{d}}^{\mathrm{b}} \\
(\mathrm{mL} / \mathrm{g})\end{array}$ & $\mathrm{R}$ & $\begin{array}{c}\mathrm{K}^{\mathrm{c}} \\
(\mathrm{UL} 95) \\
(\mathrm{cm} / \mathrm{s})\end{array}$ & $\begin{array}{l}\text { Actual } \\
\text { GW } \\
\text { Velocity } \\
\text { (ft/yr) }\end{array}$ & $\begin{array}{c}\mathrm{L} \\
(\mathrm{ft})\end{array}$ & $\Lambda \mathrm{h}$ & $\begin{array}{l}\text { Initial } \\
\text { Conc. } \\
\text { (avg.) }\end{array}$ & $\begin{array}{l}\text { Regulatory } \\
\text { Standard or } \\
\text { RBC }^{\text {d }}\end{array}$ & $\begin{array}{c}\text { Time } \\
(\mathrm{yr})\end{array}$ \\
\hline \multirow[t]{5}{*}{ 2,6-DNT } & Contour 1 & $\begin{array}{l}\text { 4036, 4006, MWS-4, 4001, 3030, } \\
\text { 3039, 3034, 4037, 3038, 4031, } \\
\text { 4029, 3029, 3028, 4028, 3033, } \\
3036,4027,4032\end{array}$ & 0.2 & 3.3 & 0.0012 & 98.2 & 1,700 & 0.0119 & $0.34 \mu \mathrm{g} / \mathrm{L}^{\mathrm{f}}$ & $0.13 \mu \mathrm{g} / \mathrm{L}^{\mathrm{f}}$ & $55^{f}$ \\
\hline & Contour 2 & $2002,2003,3003,3023$ & 0.2 & 3.3 & 0.00019 & 21.9 & 1,050 & 0.0167 & $0.41 \mu \mathrm{g} / \mathrm{L}^{\mathrm{f}}$ & $0.13 \mu \mathrm{g} / \mathrm{L}^{\mathrm{f}}$ & $182^{\mathrm{f}}$ \\
\hline & Contour 3 & 2005 & 0.2 & 3.3 & 0.000021 & 1.8 & 400 & 0.0125 & $0.27 \mu \mathrm{g} / \mathrm{L}^{\mathrm{f}}$ & $0.13 \mu \mathrm{g} / \mathrm{L}^{\mathrm{f}}$ & $536^{\mathrm{f}}$ \\
\hline & Contour 4 & 2047,2046 & 0.2 & 3.3 & 0.00104 & 89.7 & 500 & 0.0125 & $0.81 \mu \mathrm{g} / \mathrm{L}^{\mathrm{f}}$ & $0.13 \mu \mathrm{g} / \mathrm{L}^{\mathrm{f}}$ & $34^{\mathrm{f}}$ \\
\hline & Contour 5 & $\begin{array}{l}4015,2045,2052,2051,2006, \\
2053,2049,2012,4030,4039 \\
2050,2013,2033,2054,2014\end{array}$ & 0.2 & 3.3 & 0.00341 & 555.1 & 2,300 & 0.0236 & $66 \mu \mathrm{g} / \mathrm{L}$ & $0.13 \mu \mathrm{g} / \mathrm{L}$ & 85 \\
\hline \multirow[t]{2}{*}{ 2,4,6-TNT } & Contour 1 & 2046 & 0.04 & 1.5 & 0.0014 & 482.8 & 400 & 0.05 & $4.2 \mu \mathrm{g} / \mathrm{L}^{\mathrm{g}}$ & $2.8 \mu \mathrm{g} / \mathrm{L}^{\mathrm{g}}$ & $0.6^{\mathrm{g}}$ \\
\hline & Contour 2 & $2053,2049,2012$ & 0.04 & 1.5 & 0.00396 & 341.4 & 350 & 0.0125 & $75 \mu \mathrm{g} / \mathrm{Lg}$ & $2.8 \mu \mathrm{g} / \mathrm{Lg}$ & $5 \mathrm{~g}$ \\
\hline \multirow[t]{5}{*}{$1,3,5-\mathrm{TNB}$} & Contour 1 & 4031 & 0.16 & 2.7 & 0.0007 & 24.1 & 500 & 0.005 & $2.9 \mu \mathrm{g} / \mathrm{L}^{\mathrm{h}}$ & $1.8 \mu \mathrm{g} / \mathrm{L}^{\mathrm{h}}$ & $27^{\mathrm{h}}$ \\
\hline & Contour 2 & $4007,4006,4001$ & 0.16 & 2.7 & 0.00005 & 5.9 & 500 & 0.017 & $17 \mu \mathrm{g} / \mathrm{L}^{\mathrm{h}}$ & $1.8 \mu \mathrm{g} / \mathrm{L}^{\mathrm{h}}$ & $514^{\mathrm{h}}$ \\
\hline & Contour 3 & 4013 & 0.16 & 2.7 & 0.00006 & 10.4 & 200 & 0.025 & $24 \mu \mathrm{g} / \mathrm{L}^{\mathrm{h}}$ & $1.8 \mu \mathrm{g} / \mathrm{L}^{\mathrm{h}}$ & $135^{\mathrm{h}}$ \\
\hline & Contour 4 & 2046 & 0.16 & 2.7 & 0.0014 & 280 & 400 & 0.029 & $2.6 \mu \mathrm{g} / \mathrm{L}^{\mathrm{h}}$ & $1.8 \mu \mathrm{g} / \mathrm{L}^{\mathrm{h}}$ & $1^{\mathrm{h}}$ \\
\hline & Contour 5 & $\begin{array}{l}4015,2052,2006,2053,2013, \\
2033,2014,2050,2012,2049,4030\end{array}$ & 0.16 & 2.7 & 0.0026 & 179.3 & 2,400 & 0.010 & $20 \mu \mathrm{g} / \mathrm{L}^{\mathrm{h}}$ & $1.8 \mu \mathrm{g} / \mathrm{L}^{\mathrm{h}}$ & $87^{\mathrm{h}}$ \\
\hline
\end{tabular}

a Calculations presented in this table were performed by using the same methodology (i.e., Flushing Model) as that presented in the Supplemental FS (DOE 1999a). The following input parameters were also used in the calculations in addition to those shown in this table: bulk density at $1.7 \mathrm{~g} / \mathrm{cc}$ and effective porosity at 0.15 . Concentrations are based on maximum values detected in 2002 . In column heads, $R=$ retardation for the contaminant; $\mathrm{L}=$ length of the contaminated zone in a direction parallel to the direction of groundwater flow; $\Lambda \mathrm{h}=$ hydraulic gradiant present.

b Sources for distribution coefficients or $\mathrm{K}_{\mathrm{d}}$ 's presented in this table are as follows: uranium (EPA 2000); TCE and 2,6-DNT (DOE and DA 1997b); nitrate (Strenge and Peterson 1989); 2,4-DNT, 2,4,6-TNT, 1,3,5-TNB, 1,3-DNB, and NB (Brannon and Pennington 2002).

c Hydraulic conductivities or K's presented are upper $95 \%$ limits of the arithmetic means of the hydraulic conductivities for the monitoring wells included in the contours.

d Regulatory standards include the MCLs for TCE, uranium, and nitrate and the Missouri Water Quality Standards for 2,4-DNT, 1,3-DNB, and NB. RBCs developed for 2,6-DNT and 2,4,6-TNT are based on concentrations that are equivalent to a risk of 1 in 1 million to 1 in 10,000 (10-6 to $10^{-4}$ risk) for a hypothetical resident scenario. See footnote $\mathrm{h}$ for an explanation for 1,3,5-TNB.

Footnotes continue on next page. 


\section{TABLE 3.6 (Cont.)}

e Concentrations for 1,3-DNB and NB presented in this table represent the maximum concentration reported for 2002 for these contaminants from MW-2012. The average of 2002 did not exceed the standards listed for these contaminants.

f The initial concentrations shown are within the acceptable RBC range for 2,6-DNT and would be protective. The RBCs for 2,6-DNT that would be equivalent to a risk of 1 in 1 million to 1 in 10,000 for a resident scenrio are estimated to be 0.13 to $13 \mu \mathrm{g} / \mathrm{L}$. The calculations are based on the RBC that is equivalent to the $10^{-6}$ risk.

$\mathrm{g}$ The RBC range for 2,4,6-TNT is estimated to be 2.8 to $280 \mu \mathrm{g} / \mathrm{L}$ (equivalent to $10^{-6}$ to $10^{-4}$ ) for a resident scenario. The initial concentrations shown are within this range; however, calculations are based on the RBC that is equivalent to the $10^{-6}$ risk.

$\mathrm{h}$ The RBC of $1.8 \mu \mathrm{g} / \mathrm{L}$ shown for 1,3,5-TNB was estimated on the basis of toxicity information (reference dose) available during the preparation of the BRA. The reference dose has since been updated by the EPA after the BRA was finalized. On the basis of the current reference dose, the RBC that is equivalent to a hazard index of 1 for a resident scenario for 1,3,5-TNB is estimated to be $1,100 \mu \mathrm{g} / \mathrm{L}$. Therefore, site concentrations are well below this level and would already be protective, and calculations of cleanup times based on the updated RBC would not be required. 


$$
\mathrm{R}=1+\frac{\rho_{b} K_{d}}{\varphi}
$$

where

$$
\begin{aligned}
K_{d} & =\text { contaminant's distribution coefficient }(\mathrm{mL} / \mathrm{g}), \\
\Delta_{b} & =\text { bulk density of the porous medium, } \\
\mathrm{N} & =\text { effective porosity, } \\
C_{0} & =\text { initial contaminant concentration, and } \\
C_{W} & =\text { contaminant's bench mark. }
\end{aligned}
$$

A single pore volume for a contaminated zone was calculated by assuming that the contaminated zone was a parallelepiped, that is,

$$
\text { Pore volume }=t L W \phi
$$

where $L$ is the length of the contaminated zone in a direction parallel to the direction of groundwater flow.

The time required to reach the ARARs or RBCs by natural attenuation was obtained by integrating the volumetric flux over time. For a flux that is constant in time, the result is given by the following relationship:

$$
\Delta t=\frac{R \ln \left(\frac{C_{0}}{C_{W}}\right) t W L \phi}{K \nabla h t W}=\frac{R \ln \left(\frac{C_{0}}{C_{W}}\right) L \phi}{K \nabla h} .
$$

Use of this last equation above implies that once contaminated groundwater leaves a contaminated plume, it is removed from the system (i.e., downgradient locations that are initially clean do not become contaminated because of contaminant transport). For the Chemical Plant area, this assumption is reasonable because of the proximity of paleochannels that transport contaminated groundwater rapidly to the vicinity of Burgermeister Spring. With the exception of uranium, measured contaminant concentrations in groundwater have been low at Burgermeister Spring because of dilution.

Dissolved contaminants in shallow groundwater leaving the contaminated plumes would be diluted by mixing with recharge water, mixing with water in the conduit system to Burgermeister Spring, dilution with water in Lake 34, and dilution with water flowing in Dardenne Creek. 
Initial dilution of the shallow groundwater occurs by mixing with infiltrating precipitation. A dilution factor for the process can be calculated by means of the following expression (Tomasko 1992):

$$
\text { Dilution factor }=1+\frac{I L \varphi}{K \nabla h t}
$$

where $I$ is the effective recharge to the aquifer.

Additional dilution occurs when contaminated water from the Chemical Plant area mixes with initially clean water in the conduit system to Burgermeister Spring. As discussed in the remedial investigation for the GWOU (DOE and DA 1997b), about 80\% of the effective recharge to the shallow groundwater system beneath the Chemical Plant area discharges in the vicinity of Burgermeister Spring. For an effective recharge of $6.4 \mathrm{~cm} / \mathrm{yr}(2.5 \mathrm{in} . / \mathrm{yr})$ (Kleeschulte and Imes 1994), approximately 40 acre-ft of water per year would be discharged from the Chemical Plant area north of the groundwater divide. In calendar year 1996, the total flow from Burgermeister Spring was about 168 acre-ft (Kleeschulte 1997). For this flow, the discharge from the Chemical Plant area would be diluted by about a factor of 4 if all of the water from the Chemical Plant area discharged at spring 6301.

Once in the springs, aside from the processes of dilution and dispersion, any TCE would volatilize, nitrate could be taken up by plants on the edge of the springs and drainages, nitroaromatic compounds would photolyze, and uranium could be sorbed by sedimentary material or plants in the springs. This degradation is evident from monitoring data obtained from the springs and downstream reaches, including Burgermeister Spring; all COCs other than uranium have been reported at concentrations much lower than concentrations measured in the Chemical Plant area groundwater monitoring wells. Uranium concentrations have been reported at slightly higher levels than the current maximum concentrations reported for the monitoring wells because of residuals in fractured zones along losing stream segments.

Any discharge water that is not evaporated or used by plants flows into Lake 34, which provides additional dilution and discharge water to Dardenne Creek. This creek provides a natural hydrogeologic boundary between watersheds and is the northernmost boundary for water originating in the Chemical Plant area. Table 3.6 lists the relevant physical parameters that were used for calculating MNA remediation times.

\subsubsection{Evaluation of MNA for Application at the Chemical Plant Area}

\subsubsection{Effectiveness}

Naturally occurring processes (dilution and dispersion) would provide protection of human health and the environment by gradually reducing contamination concentrations over time. The remedial action conducted for the Chemical Plant Operable Unit removed the sources 
of contamination to groundwater and springs. The remaining contamination in groundwater is expected to decrease over time because infiltration of rainwater and runoff will provide a clean source of water to dilute the contaminant concentrations in the aquifer. The calculations presented above indicate a time period of approximately 100 years for the COCs to be reduced to MCL levels. This time frame is considered reasonable in the context that no active options have been identified that could provide compliance with ARARs within a shorter time frame.

\subsubsection{Implementability}

Procedures for monitoring dilution and dispersion are available and are basically the ones already in use at the site. Technical and administrative expertise and resources are available to conduct this technology; therefore, the implementability of MNA is rated as being high.

\subsubsection{Cost}

The costs for short-term and long-term operations for this alternative are expected to be moderate. Capital costs would be incurred to construct new wells and to abandon existing wells that would not be needed for the long-term network. Annual costs would be incurred for the long-term sampling and analysis of a monitoring network. Construction costs for a new well could range from $\$ 20,000$ to $\$ 90,000$, depending on whether access to the new location was available or not. New access roads or paths might have to be established if a new well was to be sited in a remote location. The annual cost for sampling and analysis could amount to $\$ 150,000$ to $\$ 450,000$ per year, depending on the size of the monitoring network. The total capital cost is estimated to be about $\$ 530,000$.

\subsection{MONITORING}

\subsubsection{Description of Monitoring}

Monitoring provides data on contaminant concentrations. These data are needed to determine whether ICs are required to maintain protection of human health and the environment. Monitoring is a fully developed technology that has been employed for more than 15 years for the groundwater at the Chemical Plant area. 


\subsubsection{Evaluation of the Monitoring Technology for Application at the Chemical Plant Area}

\subsubsection{Effectiveness}

Monitoring is an effective approach for measuring concentrations over time. These data can be used to ensure that the necessary steps are taken to prevent or minimize exposure to contaminants. Typically, ICs are implemented. Monitoring does not minimize the toxicity, mobility, or volume of the COCs.

\subsubsection{Implementability}

The implementability of monitoring at the site is rated as being high.

\subsubsection{Cost}

It is expected that the cost for monitoring at the Chemical Plant area would be moderate (e.g., a capital cost of about $\$ 400,000$ and an annual cost of $\$ 200,000$ ). Annual costs would be incurred for sampling and analysis, and capital costs would include the cost associated with abandoning existing wells in the current network that would not be needed for the long-term network monitoring regime.

\subsection{INSTITUTIONAL CONTROLS}

\subsubsection{Description of ICs}

ICs are measures that would preclude or minimize public exposure by limiting the public's access to or use of contaminated groundwater and spring water at the Chemical Plant area. These measures could take different forms, depending on whether the land was federally owned, state owned, or privately owned. For the extent of groundwater and spring water contamination, the impacted lands are owned by DOE, the DA, MDNR, MDC, and MoDOT. IC instruments being considered for federally owned properties (DOE-owned and DA-owned lands) are notations to be recorded on the federal land acquisition records. For state-owned properties, IC instruments in the form of licenses, easements, and permits are being considered. 


\subsubsection{Evaluation of ICs for Application at the Chemical Plant Area}

\subsubsection{Effectiveness}

When implemented, ICs could provide protection of human health and the environment for both the short and the long term, although over the long term, the effectiveness of ICs is considered less certain. They would not minimize the toxicity, mobility, or volume of the COCs, however. ICs would also not provide a mechanism for achieving ARARs. ICs are being considered as a component of the alternatives that are being identified to address groundwater contamination at the Chemical Plant area.

\subsubsection{Implementability}

The instruments being considered for the impacted lands owned by various federal and state entities would be in the form of restrictive licenses, easements, and permits. These controls have their basis in real property law and involve legal instruments placed in the chain of title of the site or property. These types of controls are binding on subsequent purchasers of the property and transferable; therefore, these controls are reliable for the long term. The current site interpretive center serves as an information repository, and it can be considered as an added layer to the ICs that would be implemented.

Moreover, DOE is considering enhancing the implementability of the notations on Army property by obtaining a memorandum of agreement (MOA) with the DA. DOE would also have to obtain agreements with the MDNR, MDC, and MoDOT for the state-owned properties that would be impacted. These agreements are currently being discussed with the agencies involved and are expected to be workable. DOE would be enforcing these ICs consistent with the requirements of CERCLA through yearly inspections, and the 5-year review process would further enhance the layered approach to ensuring implementation of the ICs.

\subsubsection{Cost}

The capital cost associated with ICs is expected to be low (i.e., less than \$50,000). It would mostly involve administrative costs for preparing the IC documents and agreements. The annual cost is also expected to be low. It would primarily be for performing routine inspections on an annual basis to ensure that the ICs and specified restrictions were being adhered to.

\subsection{IDENTIFICATION OF ALTERNATIVES}

An evaluation of the various technologies led to the following conclusions.

- Groundwater removal is not a viable response option for addressing groundwater and spring water contamination at the Chemical Plant area, 
primarily because of the low sustainable yield and very slow recharge of the aquifer. Only a small mass of contaminant was removed during the field studies conducted in 2001. These studies indicated that it is difficult to site a productive well in the site because of its complex geology. The hydrogeologic constraints would likely result in long time frames for achieving ARARs (comparable to the time taken by MNA). Groundwater removal would not provide better protection of human health and the environment than natural processes, and it would not be as cost effective because of the much larger cost that would be involved.

- ICO is not a viable response option for large-scale applications but could be useful for localized applications. Difficulties associated with large-scale application of the technology include the inability to deploy it across the site because of hydrogeological limitations, the uncertainty associated with potential rebound effects, and the undetermined consequences from introducing large amounts of undesirable chemical residues to the groundwater system. However, this technology was successful at achieving localized treatment of TCE, as indicated by the pilot-phase implementation. ICO is being retained as a contingency remedy because of its potential to provide localized TCE treatment.

- MNA is a reasonable response option for addressing COCs at the Chemical Plant area because it could attain remediation objectives within a reasonable time frame. Monitoring would be required to measure this technology's performance over time. Contingency measures could be employed if natural attenuation processes did not behave as expected.

- Monitoring is a viable response option being retained for consideration as a component of a remedy.

- ICs are a viable response option being retained for use as a component of a remedy. ICs could provide protection to human health and the environment during the time period needed to achieve remediation objectives.

The following alternatives, which incorporate the technologies that have been retained, have been identified for remediating the site.

1. No Further Action (used as a baseline for comparison),

2. Long-Term Monitoring with ICs, and

3. MNA with ICs.

These alternatives are further evaluated in Section 4. 


\section{ANALYSIS OF FINAL ALTERNATIVES}

The information presented in this section, in combination with information presented in the FS and Supplemental FS, served as the overall basis for selecting the preferred alternative presented in the PP (DOE 2003b).

The following three final alternatives are described and evaluated against the nine criteria stipulated in the National Oil and Hazardous Substances Pollution Contingency Plan (NCP) (EPA 1990):

- Alternative 1: No Further Action,

- Alternative 2: Long-Term Monitoring with ICs, and

- Alternative 3: MNA with ICs.

Enhanced groundwater removal that would address all COCs, combined with subsequent treatment of the extracted groundwater, is not included as an alternative to be evaluated here because implementation problems related to groundwater removal were indicated by the field studies conducted in 1998 and 2001. The ICO process for treating the entire TCE plume is also not evaluated further here on the basis of results obtained from the pilot-phase ICO, which indicated difficulties in developing a design for effective implementation (see Section 3). Because of these difficulties, it is expected that the time frame required for these alternatives to reduce contaminant concentrations would likely not be any shorter than the time needed by Alternative 3, because these other alternatives might have to rely on the same natural attenuation processes to attain ARARs.

The nine evaluation criteria are categorized into three groups: threshold criteria, primary balancing criteria, and modifying criteria. Table 4.1 presents the nine criteria and defines what is evaluated under each criterion.

- The threshold category consists of the first two criteria that an alternative must meet in order to be eligible for selection. Meeting the threshold criteria ensures that the remedial action selected will be protective of human health and the environment and that it will attain the ARARs identified at the time of the ROD or provide grounds for invoking a waiver.

- The primary balancing category consists of the next five criteria that are used to assess the relative advantages and disadvantages of each alternative. Cost effectiveness is determined by evaluating three of the five balancing criteria: long-term effectiveness and permanence; reduction of toxicity, mobility, or volume through treatment; and short-term effectiveness. Overall effectiveness is then compared with cost to ensure that the two measures are proportional 
TABLE 4.1 Nine Criteria for Evaluation of Alternatives

Criterion Description

1. Overall protection of human health and environment

2. Compliance with ARARs

3. Long-term effectiveness and permanence

4. Reduction of toxicity, mobility, or volume

5. Short-term effectiveness

6. Implementability

7. Cost

8. State acceptance

9. Community acceptance
Addresses whether the alternative provides adequate protection of human health and the environment. Evaluation focuses on a specific alternative's ability to achieve adequate protection and describes how site risks posed by each pathway are eliminated, reduced, or controlled through natural processes, treatment, engineering, or institutional controls (ICs). This evaluation also allows for consideration of any unacceptable short-term impacts associated with each alternative. Because of its broad scope, this criterion also reflects the focus of criteria 2 through 5 .

Addresses whether all state and federal ARARs are met. Evaluation focuses on whether each alternative will meet federal and state ARARs or whether there is justification for an ARAR waiver.

Addresses the risk remaining at the operable units after remediation goals have been met. Evaluation focuses on the ability of the alternative to maintain reliable protection of human health and the environment over time, once these goals have been met.

Addresses the statutory preference for selecting an alternative that permanently and significantly reduces the toxicity, mobility, or volume of hazardous substances at a site. Evaluation focuses on the extent to which this is achieved by the alternative.

Addresses the potential impacts to workers, the general public, and the environment during implementation of the alternative.

Addresses technical and administrative feasibility, including the availability and reliability of resources or materials required during implementation, and the need to coordinate with other agencies.

Addresses both capital costs and annual operation and maintenance (O\&M) costs, as well as the combined net present worth of the alternative.

Assesses the state's preference for the alternatives being considered.

Assesses the community's apparent preference for, or concerns about, the alternative being considered. This criterion will be addressed in the responsiveness summary and the record of decision (ROD) that will be prepared following the pubic comment period. 
for a remedial action. Table 4.2 presents a summary of the estimated costs for the three alternatives being evaluated.

- The modifying category is made up of the last two criteria: state acceptance and community acceptance.

\subsection{ALTERNATIVE 1: NO FURTHER ACTION}

\subsubsection{Description}

Under this alternative, no further action would be undertaken. The No Further Action alternative is evaluated as a baseline for comparison with the other alternatives. Monitoring data would not be collected under this alternative, and ICs would not be provided.

\subsubsection{Evaluation of Alternative 1 Measured against Nine Criteria}

Alternative 1 would not provide adequate protection of human health and the environment because no measures would be in place to restrict the use of groundwater. This alternative would not meet the criterion for providing long-term protectiveness and permanence. It would not provide any reduction of toxicity, mobility, or volume through treatment because no treatment would be performed. There would be no short-term impacts as a direct result of this alternative; however, there would be some very low impacts associated with having to abandon all of the monitoring wells in the existing network since there would be no further need for them. There would not be any implementability issues because no activity would need to be implemented. However, a cost of approximately $\$ 520,000$ is estimated for the abandonment of existing monitoring wells. The state does not support this alternative. Community acceptance will be evaluated on the basis of comments received during the review period for the Proposed Plan.

\subsection{ALTERNATIVE 2: LONG-TERM MONITORING WITH INSTITUTIONAL CONTROLS}

\subsubsection{Description}

Under this alternative, no active remediation would take place, but ICs would be implemented and monitoring data would be collected. The data collected would ensure that protection of human health and the environment was being provided or maintained; that is, the data would serve as the basis for establishing the appropriateness of the IC component of this alternative. 
TABLE 4.2 Summary Cost Estimate for the Final Alternatives (\$)

\begin{tabular}{|c|c|c|c|}
\hline Cost Item & $\begin{array}{c}\text { Alternative 1: } \\
\text { No Further Action }\end{array}$ & $\begin{array}{c}\text { Alternative 2: } \\
\text { Long-Term } \\
\text { Monitoring with ICs }\end{array}$ & $\begin{array}{l}\text { Alternative 3: } \\
\text { MNA with ICs }\end{array}$ \\
\hline Abandonment of wells & $520,000^{\mathrm{a}}$ & $450,000^{\mathrm{b}}$ & $325,000^{\mathrm{c}}$ \\
\hline Construction of new wells & 0 & $\$ 0$ & $205,000^{\mathrm{d}}$ \\
\hline Total capital cost & 520,000 & 450,000 & 530,000 \\
\hline Analysis of samples ${ }^{\mathrm{e}}$ & 0 & $3,500^{\mathrm{f}}$ & $14,000^{\mathrm{g}}$ \\
\hline Shipping and supplies & 0 & 400 & 1,400 \\
\hline Labor & 0 & 40,000 & 160,000 \\
\hline $\begin{array}{l}\text { Routine well maintenance and } \\
\text { replacement }\end{array}$ & 0 & 30,000 & 50,000 \\
\hline $\begin{array}{l}\text { Inspections, report preparation, and } \\
\text { administration }\end{array}$ & 0 & 70,000 & 70,000 \\
\hline $10 \%$ contingency ${ }^{\mathrm{i}}$ & 0 & 15,000 & 30,000 \\
\hline Total annual cost & 0 & 160,000 & 340,000 \\
\hline Present net worth of annual cost $\mathrm{t}^{\mathrm{j}}$ & 0 & $2,250,000$ & $4,850,000$ \\
\hline Total present net worth ${ }^{\mathrm{k}}$ & 520,000 & $2,700,000$ & $5,380,000^{1}$ \\
\hline
\end{tabular}

a Abandonment of 79 wells.

b Abandonment of 60 wells.

c Abandonment of 41 wells.

d Construction of 2 wells. Includes cost for establishing access roads and other associated activities.

e Samples were from 38 existing DOE wells, 2 new DOE wells, 1 Army well, and 4 springs. Samples were analyzed for all or a combination of the COCs.

f Sampling frequency is assumed to be annual.

g Sampling frequency is assumed to be semiannual, but estimate also takes into account an average of some sampling done quarterly and some done annually.

$\mathrm{h}$ Cost is based on one-third of similar costs shown in the long-term surveillance and monitoring (LTS\&M) Plan to carry out activities primarily related to ICs. LTS\&M Plan cost estimates are for three operable units.

i Estimate is for $10 \%$ contingency of the items shown above and not for any contingency actions.

j Present net worth of annual cost was calculated by using a discount rate of $7 \%$ and assuming 100 years of monitoring.

$\mathrm{k}$ Total present net worth combines the present net worths of the annual cost, total capital cost, and cost for the abandonment of the wells that remain at the end of the remedial (monitoring) action period. It is assumed to be (in today's dollars) $\$ 225,000$ for Alternative 2 and $\$ 330,000$ for Alternative 3. The total capital cost shown was not discounted because it is assumed that it will be expended by the first year of the remedial action.

1 The cost for the contingency of ICO localized treatment of TCE is estimated to be approximately $\$ 1,000,000$, which is similar to the amount expended for the pilot-phase ICO. 
For the long-term monitoring component of this alternative, data would be in the form of contaminant concentrations collected from a network of monitoring wells. Designs for the network would be presented in the remedial design and remedial action (RD/RA) reports. The existing network of monitoring wells would be used as the initial basis for the design and would be optimized with the construction of new wells, as necessary.

Data from the monitoring network of wells would be collected for a period of time deemed necessary to provide protection of human health and the environment, though not necessarily until contaminant concentrations met ARARs. The period of monitoring would be defined in the RD/RA phase that would follow the ROD. It is expected that the period of monitoring would be determined in conjunction with ICs that would be implemented as part of this alternative.

As required by CERCLA, a review would be conducted no less than every five years because contaminants would remain in site groundwater at levels above those that allow unlimited use and unrestricted exposure.

For the purpose of estimating cost, a preliminary network, which consists of 19 wells to be monitored for the various COCs on an annual basis, was used. For this alternative, the estimated capital cost is $\$ 450,000$. This cost results primarily from the abandonment of about 60 wells that would not be needed for the long-term monitoring network. The estimated annual cost is $\$ 160,000$. This cost would result primarily from analytical and labor expenses associated with sampling, inspections primarily related to ICs, and performing routine maintenance and from other administrative expenses. The present net worth of the annual cost is about $\$ 2,250,000$, assuming 100 years of monitoring. The 100 -year time period is based on the calculations used to determine the time it would take for the natural attenuation process to reduce contaminant concentrations to MCLs. The total present net worth (including capital cost) for this alternative is $\$ 2,700,000$. Table 4.2 lists various activities included in the cost estimates.

For the IC component of this alternative, restrictions would be implemented within the boundary of the Chemical Plant and in the areas surrounding (outside) the Chemical Plant. Restrictions for groundwater use would be implemented within the Chemical Plant boundary, while restrictions for groundwater and spring water use would be implemented in the area outside the Chemical Plant.

For the area within the site boundary that is under the jurisdictional control of DOE, the restrictions would be in the form of a notation placed on the federal acquisition records. This notation would specify the restrictions imposed by DOE that would limit the use of the groundwater for investigative (sampling) purposes only. Restrictions specified in the notation would accrue to a succeeding owner or owners of the land. Similar restrictions would be imposed on DA property outside the Chemical Plant boundary. An MOA would be prepared between DOE and DA to enhance the enforceability of the planned notation.

For the areas surrounding the site boundary that are owned by the MDNR, MDC, and MoDOT, the IC instruments would include indefinite-term licenses, easements, or permits, as appropriate. These instruments would be prepared to specify that current owners or users of the 
land must not access the shallow groundwater for all uses and must not access groundwater at the springs for uses other than recreational. They would also specify that DOE must continue to have the right to monitor and analyze the groundwater and spring water for investigative purposes. The ICs would remain until conditions were determined to be protective as evaluated in the 5-year CERCLA reviews.

Monitoring and enforcement of the ICs would be performed by DOE and would include (1) routine (annual) inspections to look for indications of groundwater withdrawal or spring water use and (2) contacts with land owners to ensure their awareness of the restrictions in place, to be conducted before the annual reviews. Inspectors would ensure that land use continued to be in compliance with the terms of the notations, license, easement, or permit and with the restrictions contained in these instruments. Enforcement of the ICs would be accomplished under CERCLA and could include litigation in federal courts to ensure compliance, if needed.

\subsubsection{Evaluation of Alternative 2 Measured against Nine Criteria}

Alternative 2 would provide protection of human health and the environment primarily because ICs would be implemented. Monitoring data would be collected to provide information to support the implementation of ICs. ICs would be in place to ensure protectiveness during the remedial action period. These ICs would be used to prevent or limit access to and use of groundwater and spring water, thereby preventing or limiting potential exposure to the contaminants. Under this alternative, ARARs would be waived on the basis of a technical impracticability determination.

No reduction of toxicity, mobility, or volume through treatment would be provided by this alternative. Potential impacts to workers, the general public, and the environment during implementation of the alternative are expected to be low. No implementability issues have been identified for this alternative, since conventional and readily available methods for monitoring, construction, and abandonment of wells would be used for the monitoring component. The preparation of notations, license, easement, and permits between DOE and the various state agencies and the DA is expected to be workable.

Capital costs are estimated to be about $\$ 450,000$, with annual costs estimated to be about $\$ 160,000$. The present net worth cost is estimated to be $\$ 2,700,000$ on the basis of the assumption of a 100-year time frame for monitoring. The state does not favor this alternative because it involves invoking waivers for the chemical-specific ARARs. The public has expressed concern over this alternative, as reflected in public comments received on the PP that was issued in 1999 (DOE 1999b). That PP contained Alternative 2 as the preferred alternative for all the COCs except TCE. It proposed treating the TCE by ICO. 


\subsection{ALTERNATIVE 3: MONITORED NATURAL ATTENUATION WITH INSTITUTIONAL CONTROLS}

\subsubsection{Description}

This alternative would involve the collection of monitoring data to verify the effectiveness of naturally occurring processes to reduce contaminant concentrations. Dilution and dispersion are the primary natural processes identified that are reducing all contaminant concentrations in groundwater at the Chemical Plant area (DOE 1999a). However, because of the wide range in hydraulic conductivities and the karst nature of the aquifer across the contaminated areas, uncertainties are associated with the remedial time frames predicted. Calculations indicate remedial time frames of approximately 100 years to approach ARARs (see Section 3).

The removals of contamination sources that were performed per the Chemical Plant ROD (DOE 1993) are expected to ultimately result in decreasing groundwater contaminant levels, since no further contribution to the contamination would occur. Conditions do not appear to be favorable for biological or chemical processes degrading the TCE, nitroaromatic compounds, or nitrate; however, sorption of uranium is expected to be occurring to some extent. In addition, discharged groundwater (to the surface springs, primarily Burgermeister Spring and the Southeast Drainage) is subject to further extensive dilution and physical and chemical degradation. In other words, once in the springs, TCE would volatilize, nitrate could be taken up by plants on the edge of the springs and drainages, nitroaromatic compounds would photolyze, and uranium could be sorbed by sedimentary material and plants in the springs. Monitoring to determine the continued occurrence of dilution and dispersion would be performed. The monitoring activities would essentially be done to verify contaminant concentration decreases at the various monitoring wells and discharge points (e.g., Burgermeister Spring). Monitoring strategies for the COCs are presented in Section 5, which also stipulates concentrations and events that would trigger the appropriate contingency actions. These contingency actions would include an increase in sampling frequency, a reevaluation of MNA time frames, and a reevaluation of ICs. For TCE, localized treatment of TCE would also be included as a contingency. For uranium, the contingencies would include additional fish sampling at Lake 34 .

As part of this alternative, ICs would also be required to provide protection of human health and the environment because of the approximately 100 years that it would take to approach ARARs. The ICs would provide use restrictions for groundwater and springs. The ICs that would be implemented would be the same as those described for Alternative 2 (see Section 3.1.2.1).

As required by CERCLA, a review would be conducted every five years while the remedial action was being implemented, since contaminants would remain in site groundwater at levels above those that allow for unlimited use and unrestricted exposure. 


\subsubsection{Evaluation of Alternative 3 Measured against Nine Criteria}

Alternative 3 would provide adequate protection of human health and the environment because ICs would be implemented during the remediation period. Performance monitoring would be conducted to ensure groundwater conditions remained protective and that contaminant concentrations were behaving as expected, consistent with the current understanding of the site hydrogeology and behavior of the COCs. The natural attenuation processes of dilution and dispersion are expected to attenuate contaminant concentrations to levels that would allow use of the groundwater for unlimited use and unrestricted exposure (i.e., to ARARs). It is expected that the attenuation would occur within a reasonable time frame.

Long-term effectiveness and permanence would be provided by this alternative because once ARARs were met, it is expected that contaminant concentrations would remain at levels equivalent to ARARs or lower, since the various sources of contamination to groundwater would have been removed. Reduction of toxicity, mobility, or volume through treatment would not be provided by this alternative.

Procedures or techniques for performance monitoring and implementation of ICs associated with this alternative are available and could be implemented without much difficulty. The capital cost associated with this alternative is estimated to be approximately $\$ 530,000$. This cost covers the construction of two new wells and the abandonment of 41 existing wells that would not be needed on the basis of the preliminary design described in Section 5. An annual cost of about $\$ 340,000$ is estimated, which covers activities such as sampling and analysis and inspections for ICs. The total present net worth cost is estimated to be about $\$ 5,400,000$ on the basis of 100 years of implementation. The costs are based on a preliminary monitoring network consisting of 38 existing DOE wells, 2 new DOE wells, 1 DA well, and 4 springs.

The MDNR has expressed support for this alternative because it provides for contingencies and does not require ARAR waivers. Community acceptance would be evaluated after the public review period and would be reflected in the responsiveness summary to be provided with the upcoming ROD.

\subsection{COMPARATIVE ANALYSIS OF THE FINAL ALTERNATIVES}

The alternatives are compared against each other on the basis of the nine CERCLA evaluation criteria in Table 4.3. The state and the community will have the opportunity to provide further comments regarding the preferred alternative and other final alternatives during the comment period for the PP.

On the basis of the comparative analysis presented in Table 4.3, DOE has determined that Alternative 3 would provide the best balance of trade-offs among the alternatives considered. Although it would have the highest overall cost of the three alternatives, Alternative 3 would provide the greatest level of protection to human health and the environment through the mechanisms that would be in place. Performance measures would be established to ensure 


\section{TABLE 4.3 Comparative Analysis of the Final Alternatives}

\begin{tabular}{|c|c|c|c|}
\hline Criterion & $\begin{array}{l}\text { Alternative 1: } \\
\text { No Action }\end{array}$ & $\begin{array}{c}\text { Alternative 2: } \\
\text { Long-Term Monitoring with } \\
\text { Institutional Controls } \\
\end{array}$ & $\begin{array}{l}\text { Alternative 3: } \\
\text { Monitored Natural Attenuation with } \\
\text { Institutional Controls }\end{array}$ \\
\hline $\begin{array}{l}\text { Overall protection of human } \\
\text { health and the environment }\end{array}$ & $\begin{array}{l}\text { Would not provide adequate protection } \\
\text { of human health and the environment } \\
\text { because the use of groundwater would } \\
\text { not be prevented. No ICs would be } \\
\text { provided under this alternative. }\end{array}$ & $\begin{array}{l}\text { Would be adequately protective of human } \\
\text { health and the environment because ICs } \\
\text { would be implemented. Monitoring data } \\
\text { would be collected to ensure that } \\
\text { appropriate ICs were implemented. }\end{array}$ & $\begin{array}{l}\text { Would provide a greater level of protectiveness } \\
\text { of human health and the environment than } \\
\text { Alternative } 2 \text {, because monitoring data would } \\
\text { also be collected to verify the performance of } \\
\text { natural attenuation processes. ICs would be } \\
\text { implemented during the attenuation period. } \\
\text { MNA is also protective because it meets } \\
\text { ARARs and remediation objectives. }\end{array}$ \\
\hline Compliance with ARARs & $\begin{array}{l}\text { Data would not be available to } \\
\text { determine if contaminant } \\
\text { concentrations had decreased to } \\
\text { chemical-specific ARARs for TCE, } \\
\text { nitrate, uranium, 2,4-DNT, 1,3-DNB, } \\
\text { and NB. }\end{array}$ & $\begin{array}{l}\text { Would require an ARAR waiver because a } \\
\text { mechanism would not be in place to } \\
\text { determine when and if chemical-specific } \\
\text { ARARs for TCE, nitrate, uranium, } \\
\text { 2,4-DNT, 1,3-DNB, and NB were being } \\
\text { met. }\end{array}$ & $\begin{array}{l}\text { Calculations indicate a time period of } \\
\text { approximately } 100 \text { years to approach the } \\
\text { chemical-specific ARAR for TCE. Chemical- } \\
\text { specific ARARs for nitrate, uranium, } 2,4-\mathrm{DNT} \text {, } \\
1,3 \text {-DNB, and NB would be met in } \\
\text { approximately } 4 \text { to } 80 \text { years, depending on the } \\
\text { contaminant. }\end{array}$ \\
\hline $\begin{array}{l}\text { Long-term effectiveness and } \\
\text { permanence }\end{array}$ & Not applicable. & $\begin{array}{l}\text { Would meet this criterion by } \\
\text { implementation of ICs. }\end{array}$ & $\begin{array}{l}\text { The remedy would be fully effective, and } \\
\text { permanent remedial objectives would be met. } \\
\text { However, during the remedial action period, } \\
\text { ICs would have to be implemented to maintain } \\
\text { protection of human health and the } \\
\text { environment. }\end{array}$ \\
\hline $\begin{array}{l}\text { Reduction of toxicity, } \\
\text { mobility, or volume through } \\
\text { treatment }\end{array}$ & $\begin{array}{l}\text { No reduction of toxicity, mobility, and } \\
\text { volume through treatment would be } \\
\text { provided. }\end{array}$ & $\begin{array}{l}\text { Like Alternatives } 1 \text { and } 3 \text {, no reduction of } \\
\text { toxicity, mobility, or volume through } \\
\text { treatment would be accomplished because } \\
\text { the contaminated groundwater would not be } \\
\text { treated. }\end{array}$ & $\begin{array}{l}\text { Like Alternatives } 1 \text { and } 2 \text {, no reduction of } \\
\text { toxicity, mobility, or volume through treatment } \\
\text { would be accomplished because the } \\
\text { contaminated groundwater would not be } \\
\text { treated. }\end{array}$ \\
\hline
\end{tabular}


TABLE 4.3 (Cont.)

\begin{tabular}{|c|c|c|c|}
\hline Criterion & $\begin{array}{l}\text { Alternative 1: } \\
\text { No Action }\end{array}$ & $\begin{array}{c}\text { Alternative } 2: \\
\text { Long-Term Monitoring with } \\
\text { Institutional Controls } \\
\end{array}$ & $\begin{array}{c}\text { Alternative 3: } \\
\text { Monitored Natural Attenuation with } \\
\text { Institutional Controls } \\
\end{array}$ \\
\hline Short-term effectiveness & No activity would be conducted. & $\begin{array}{l}\text { Potential impacts are expected to be low, } \\
\text { with less than one case of occupational } \\
\text { injury and no occupational fatalities during } \\
\text { proposed monitoring well construction. Any } \\
\text { potential short-term environmental impacts } \\
\text { would be limited to the immediate vicinity } \\
\text { of the GWOU, and mitigative measures } \\
\text { would be implemented to ensure minimal } \\
\text { impacts to areas outside the GWOU. }\end{array}$ & $\begin{array}{l}\text { Potential impacts are expected to be low, with } \\
\text { less than one case of occupational injury and } \\
\text { no occupational fatalities during proposed } \\
\text { monitoring well construction. Any potential } \\
\text { short-term environmental impacts would be } \\
\text { limited to the immediate vicinity of the } \\
\text { GWOU, and mitigative measures would be } \\
\text { implemented to ensure minimal impacts to } \\
\text { areas outside the GWOU. }\end{array}$ \\
\hline Implementability & No activity would be conducted. & $\begin{array}{l}\text { Few implementability concerns because of } \\
\text { the limited actions taken. Current } \\
\text { monitoring operations would continue with } \\
\text { the use of readily available resources. } \\
\text { Instruments for ICs have been identified. }\end{array}$ & $\begin{array}{l}\text { Few implementability concerns because of the } \\
\text { nature of actions taken. Current monitoring } \\
\text { operations would continue with the use of } \\
\text { readily available resources. Instruments for ICs } \\
\text { have been identified. }\end{array}$ \\
\hline Cost & $\begin{array}{l}\text { One-time cost for the abandonment of } \\
\text { wells is estimated to be } \$ 520,000 \text {. } \\
\text { No annual cost is associated with } \\
\text { Alternative } 1 \text {. }\end{array}$ & $\begin{array}{l}\text { Capital cost is estimated to be } \$ 450,000 \text {, } \\
\text { annual cost is estimated to be } \$ 160,000 \text {, and } \\
\text { present net worth cost is estimated to be } \\
\$ 2,700,000 \text {. }\end{array}$ & $\begin{array}{l}\text { Capital cost is estimated to be } \$ 530,000 \text {, } \\
\text { annual cost is estimated to be } \$ 340,000 \text {, and } \\
\text { present net worth cost is estimated to be } \\
\$ 5,400,000 \text {. }\end{array}$ \\
\hline State acceptance & Not acceptable. & $\begin{array}{l}\text { Not acceptable because ARAR waivers } \\
\text { would be required. }\end{array}$ & $\begin{array}{l}\text { The MDNR has indicated support for this } \\
\text { alternative, provided that adequate } \\
\text { performance measures and contingencies are } \\
\text { incorporated. }\end{array}$ \\
\hline Community acceptance & $\begin{array}{l}\text { Community acceptance would be } \\
\text { evaluated on the basis of comments } \\
\text { received on the Proposed Plan during } \\
\text { the public comment period. }\end{array}$ & $\begin{array}{l}\text { Community acceptance would be evaluated } \\
\text { on the basis of comments received on the } \\
\text { Proposed Plan during the public comment } \\
\text { period. }\end{array}$ & $\begin{array}{l}\text { Community acceptance would be evaluated on } \\
\text { the basis of comments received on the } \\
\text { Proposed Plan during the public comment } \\
\text { period. }\end{array}$ \\
\hline
\end{tabular}


protectiveness and compliance with chemical-specific ARARs within the time frame determined to be reasonable. The development of the design for the performance monitoring strategy would require more effort than that required for Alternative 2; however, once developed, it should be readily implementable. The establishment of ICs would require discussions with the DA and various state agencies to obtain the necessary agreements, but the ICs are expected to be workable. Therefore, the preferred alternative for the remaining groundwater contamination at the Chemical Plan area is MNA with ICs. Contingency activities would also be identified as part of this proposal in case attenuation processes would not result in the expected decreases in contaminant concentrations over time. 


\section{PRELIMINARY DESIGN FOR THE PREFERRED ALTERNATIVE}

This section provides the preliminary designs for the two main components of the preferred alternative. Section 5.1 discusses the preliminary plans for the identification, preparation, implementation, and enforcement of the ICs needed on DOE, MDC, MoDOT, and DA property. Section 5.2 presents the proposed monitoring strategy for each of the groundwater COCs at the Chemical Plant area. The details addressing performance monitoring for TCE, nitrate, uranium, and the nitroaromatic compounds are presented in Tables 5.1 through 5.4, respectively, at the end of this chapter. The details are preliminary; the MDNR has outstanding issues related to some the specific items presented in the tables. DOE, the EPA, and the MDNR will be conducting further discussions on the details presented before final designs are incorporated in the RD/RA Work Plan.

\subsection{INSTITUTIONAL CONTROLS}

The implementation of ICs is a necessary component of the alternatives evaluated for the GWOU PP, with the exception of the No Further Action alternative. ICs would be needed to ensure protection of human health and the environment during the remedial action period to restrict groundwater use for purposes other than investigative (sampling) activities.

For the IC component of the preferred alternative, instruments or mechanisms that are appropriate with regard to land ownership and that are considered to be implementable, reliable, and enforceable were considered. The affected land area would involve federally owned and state-owned properties. To restrict groundwater and spring water use effectively, restrictions on groundwater use would be implemented within the Chemical Plant boundary that is under the jurisdictional control of DOE, while restrictions on groundwater and spring water use would be implemented at the MDC, MDNR, MoDOT, and DA properties surrounding the Chemical Plant. The IC area extends to Burgermeister Spring to the north and includes the Southeast Drainage to the south. A hydraulic buffer zone of $305 \mathrm{~m}(1,000 \mathrm{ft}$ ) to preclude well placement (which could alter the flow path of contaminated groundwater) would also be included in the IC area from the site to the Burgermeister Spring (see Figure 5.1).

For the Chemical Plant property, a notation would be placed on the federal acquisition land records, with specified restrictions to accrue to succeeding owners of the land. Restrictions would prohibit the construction of a residential dwelling or facility for human occupancy. Except for giving DOE access to the groundwater for sampling and investigative purposes, the notation would prohibit access to groundwater for use. These restrictions would be for an indefinite term. If the land was conveyed to another party, notice of the restrictions or prohibitions would be placed within the conveyance document. Enforcement of these ICs would be accomplished under CERCLA and could include litigation in federal courts for compliance.

For MDC, MDNR, MoDOT, and DA properties in the area surrounding but outside the Chemical Plant, indefinite-term licenses, easements, and permits, as applicable, are being 


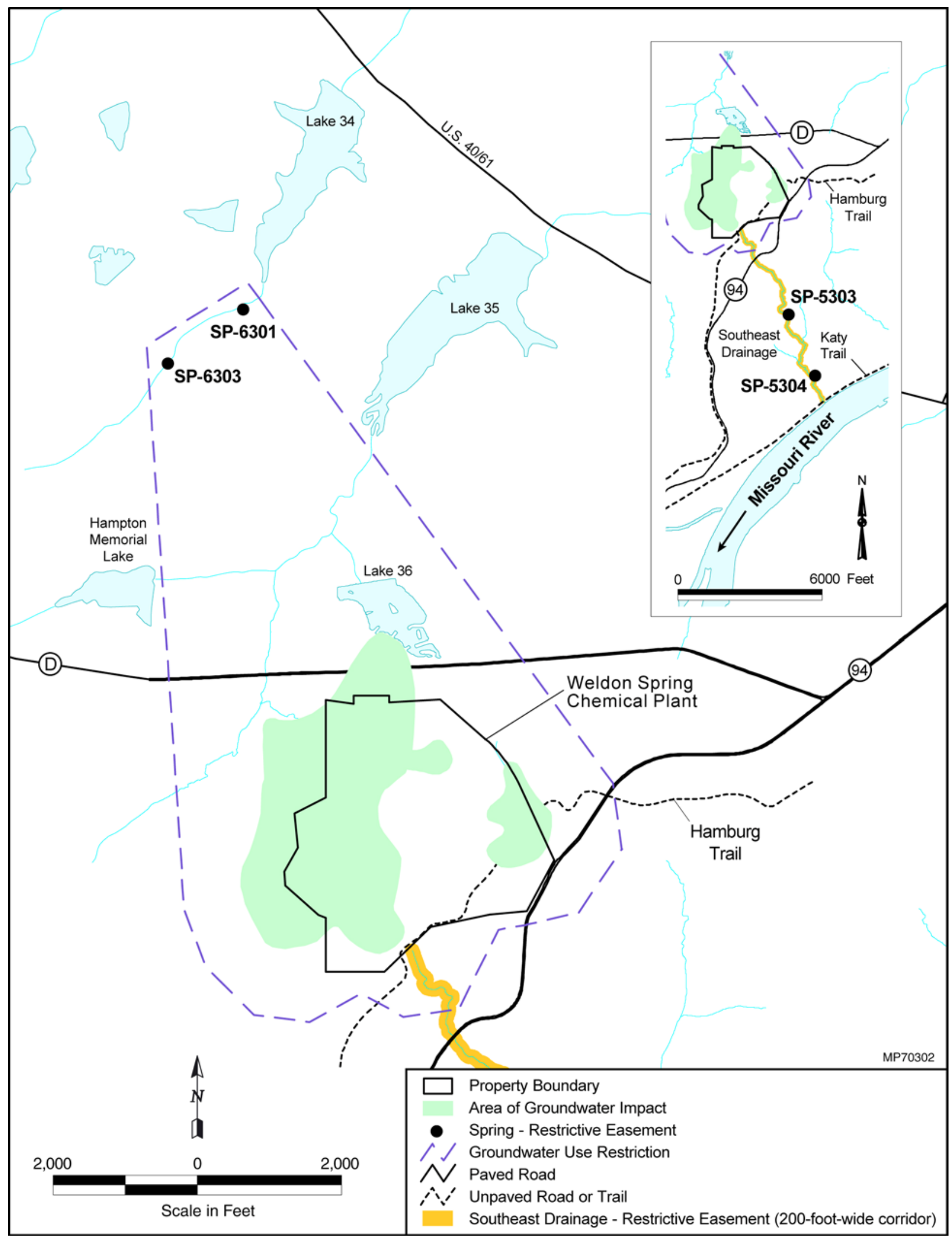

FIGURE 5.1 Locations of Institutional Controls at the Chemical Plant Area 
considered. These instruments would specify groundwater and spring water access restrictions for the current owners or users of the land. These instruments would also give DOE continued access to monitor and analyze the groundwater for a period of time to be defined.

Routine (annual) inspections would be conducted to look for indications of groundwater use and spring water use that were inconsistent with the specified restrictions. On an annual basis, affected landowners would also be contacted to ensure that they were aware of the restrictions imposed. The inspections would ensure that use would continue to be in compliance with the terms of the IC instruments in use. These long-term activities would be incorporated into the site long-term surveillance and maintenance (LTS\&M) plan (DOE 2003a).

\subsection{PROPOSED PERFORMANCE MONITORING STRATEGY}

The objectives of the performance monitoring effort for the preferred alternative are to (a) monitor the unweathered or deeper portion of the shallow aquifer to make sure that contamination does not go any deeper than it currently is, (b) verify that natural attenuation is occurring as expected, (c) ensure that the contaminant plumes are not expanding or migrating unexpectedly, (d) demonstrate that contaminant concentrations at the springs are protective on the basis of its current recreational use, (e) perform upgradient monitoring, and (f) demonstrate hydrologic stability. An additional objective ( $\mathrm{g}$ ) has been included for TCE to monitor rebound of concentrations in the area of influence of the pilot-phase ICO.

The expectation is that the contaminant plumes will continue to disperse and become more diluted with natural recharge from rainwater. Since the various sources of contamination have been removed as a result of the remedial action for the Chemical Plant Operable Unit, groundwater quality should continue to improve. The overall area of contamination should not become significantly larger than it currently is. The IC boundary shown in Figure 5.1 takes into account any increase in size due to dispersion. The contamination should not go any deeper than it already has (on the basis of site knowledge indicating that the preferential flow of shallow groundwater is predominantly horizontal and toward Burgermeister Spring). The potential risk to the recreational visitor should remain very low.

The monitoring strategies presented at the end of this section in Tables 5.1-5.4 involve sampling of monitoring wells located within the plume (at locations with the highest concentrations), at the edge of the plume, at likely downgradient locations where lower concentrations of contaminants may be observed as a result of dispersion, and at locations where potential exposure could occur at the springs. Monitoring wells completed in both the weathered and unweathered portion of the aquifer were included.

Within the proposed monitoring network for MNA, selected locations have been assigned specific trigger concentrations that invoke specified contingency responses, ranging from an increase in sampling frequency, to a reevaluation of predicted MNA time frames, to a reevaluation of ICs. For TCE, the contingencies include localized treatment of TCE by using ICO. For uranium, the contingencies include additional fish sampling at Lake 34. 
Trigger concentrations are presented in Tables 5.1-5.4 for the various COCs. For the trigger concentrations within the plumes, concentrations were based on historical highs for the particular COC; downgradient of the plumes, the trigger concentrations were selected on the basis of expectations about dispersion within the IC area; and at the springs, the trigger concentrations were based on health assessments and historical trends. 
TABLE 5.1 Preliminary Monitored Natural Attenuation Performance Monitoring for TCE (to be finalized in the RD/RA Work Plan)

\begin{tabular}{|c|c|c|c|c|c|}
\hline Objective & $\begin{array}{l}\text { Monitoring } \\
\text { Well }^{\mathrm{a}}\end{array}$ & Rationale for Selection & Sampling Frequency & $\begin{array}{c}\text { Trigger Concentration } \\
\text { or Event }\end{array}$ & Contingency Action \\
\hline \multirow[t]{2}{*}{$\begin{array}{l}\text { A. Delineate the } \\
\text { vertical extent of TCE } \\
\text { contamination. }\end{array}$} & $\begin{array}{l}\text { UW-1 } \\
\text { (w/MW-4037) }\end{array}$ & $\begin{array}{l}\text {-It will be in a good location for } \\
\text { showing vertical characterization of the } \\
\text { TCE extent and is downgradient of the } \\
\text { impacted area. } \\
\text {-It will be cased } 10 \mathrm{ft} \text { within the } \\
\text { unweathered unit with a } 10-\mathrm{ft} \text { screen. }\end{array}$ & $\begin{array}{l}\text {-Sample quarterly for first } \\
2 \text { years, then as outlined } \\
\text { under this program. }\end{array}$ & $\begin{array}{l}\text { a. When a concentration } \\
\text { of } 3 \mu \mathrm{g} / \mathrm{L} \text { or greater is } \\
\text { detected and confirmed at } \\
\text { either Well UW- } 1 \text { or } \mathrm{W}-1 \text {. }\end{array}$ & $\begin{array}{l}\text { a. Conduct additional } \\
\text { characterization to determine the } \\
\text { extent of contamination. }\end{array}$ \\
\hline & $\mathrm{W}-1$ & $\begin{array}{l}\text {-It will be installed along the flow path } \\
\text { from the TCE impact area to SP- } 6301 \text {. } \\
\text {-It will be installed at a predetermined } \\
\text { location between MWS- } 2 \text { and } \\
\text { MW- } 4036 \text { (approximately } 1,000 \mathrm{ft} \\
\text { northwest of MW- } 4001 \text { ). } \\
\text {-It will be cased within a permeable } \\
\text { portion of the weathered unit as } \\
\text { determined by packer tests with a } 10-\mathrm{ft} \\
\text { screen. } \\
\text {-Location will be optimized by drilling } \\
\text { up to } 3 \text { boreholes perpendicular to the } \\
\text { estimated location of the paleofeature in } \\
\text { an attempt to intercept the preferential } \\
\text { flow pathway. }\end{array}$ & & & \\
\hline
\end{tabular}

B. Verify that natural MW-2038 attenuation is occurring as expected.
- TCE concentrations experienced dramatic declines from $>1,000 \mu \mathrm{g} / \mathrm{L}$ in 1996 to $<50 \mu \mathrm{g} / \mathrm{L}$ at present.

-It demonstrates dissipation of the plume.

-It was not impacted by the pump tests or ICO.
-Sample semiannually for 2 years after initiation of the long-term monitoring, as described in the RD/RA Work Plan.

-Reevaluate/optimize as part of 5-year reviews. a. When a concentration is greater than established baseline levels at any " $\mathrm{B}$ " well. Baseline is defined as the arithmetic mean plus 3 standard deviation as determined from data collected during 2001 and 2002 a. Increase sampling frequency to quarterly. After 4 quarters: (1) If concentrations fall below baseline levels, return to previous sampling frequency. (2) If concentrations remain above baseline levels, continue quarterly sampling and recalculate MNA time frames. 
TABLE 5.1 (Cont.)

\begin{tabular}{|c|c|c|c|c|c|}
\hline Objective & $\begin{array}{l}\text { Monitoring } \\
\text { Wella }^{\mathrm{a}}\end{array}$ & Rationale for Selection & Sampling Frequency & $\begin{array}{c}\text { Trigger Concentration } \\
\text { or Event } \\
\end{array}$ & Contingency Action \\
\hline \multirow[t]{4}{*}{ B (Cont.) } & MW-3030 & $\begin{array}{l}\text {-TCE concentrations are within } \\
100-\mu \mathrm{g} / \mathrm{L} \text { contour and stable at } \\
200-300 \mu \mathrm{g} / \mathrm{L} \text {. } \\
\text {-It was not impacted by the pump test } \\
\text { or ICO. } \\
\text {-It is along the preferential flow path. }\end{array}$ & & $\begin{array}{l}\text { b. When a concentration } \\
\text { is }>1,000 \mu \mathrm{g} / \mathrm{L} \text { at any " } \mathrm{B} \text { " } \\
\text { well on the basis of } \\
\text { confirmatory sampling. }\end{array}$ & $\begin{array}{l}\text { b. If two consecutive quarters } \\
\text { with confirmatory sampling show } \\
\text { concentrations of }>1,000 \mu \mathrm{g} / \mathrm{L} \text {, } \\
\text { invoke localized ICO or better } \\
\text { remediation alternative. }\end{array}$ \\
\hline & MW-3039 & $\begin{array}{l}\text {-TCE concentrations are within } \\
100-\mu \mathrm{g} / \mathrm{L} \text { contour but have increased } \\
\text { some since installation. } \\
\text {-It was not impacted by the pump test } \\
\text { or ICO. } \\
\text {-It is along the preferential flow path. }\end{array}$ & & & \\
\hline & MW-4001 & $\begin{array}{l}\text {-TCE concentrations are stable at } \\
<10 \mu \mathrm{g} / \mathrm{L} \text {. } \\
\text {-It is screened in weathered/ } \\
\text { unweathered (W/UW), but primarily } \\
\text { weathered. } \\
\text {-It is in a good location downgradient } \\
\text { from source for measuring plume } \\
\text { dissipation. } \\
\text {-It is better than newer MW-4006 in } \\
\text { same well cluster. }\end{array}$ & & & \\
\hline & MW-4029 & $\begin{array}{l}\text { - TCE concentrations are within } \\
500-\mu \mathrm{g} / \mathrm{L} \text { contour. } \\
\text {-It was not impacted by pump and treat } \\
(\mathrm{P} \& \mathrm{~T}) \text {. } \\
\text {-It was slightly impacted from ICO, but } \\
\text { the TCE concentrations rebounded to } \\
500-600 \mu \mathrm{g} / \mathrm{L} \text {. }\end{array}$ & & & \\
\hline
\end{tabular}


TABLE 5.1 (Cont.)

\begin{tabular}{|c|c|c|c|c|c|}
\hline Objective & $\begin{array}{l}\text { Monitoring } \\
\text { Wella }^{\mathrm{a}}\end{array}$ & Rationale for Selection & Sampling Frequency & $\begin{array}{c}\text { Trigger Concentration } \\
\text { or Event } \\
\end{array}$ & Contingency Action \\
\hline \multirow[t]{2}{*}{ B (Cont.) } & MW-4031 & $\begin{array}{l}\text {-TCE concentrations are within } \\
100-\mu \mathrm{g} / \mathrm{L} \text { contour and stable from } 120 \\
\text { to } 220 \mu \mathrm{g} / \mathrm{L} \text {. } \\
\text {-It was not impacted by P\&T or ICO. } \\
\text {-It is along the flow path. }\end{array}$ & & & \\
\hline & MW-4037 & $\begin{array}{l}\text {-TCE concentrations have increased } \\
\text { since installation from } 1.6 \text { to } 30 \mu \mathrm{g} / \mathrm{L} \text {. } \\
\text {-It is in a good location downgradient } \\
\text { from the source for measuring plume } \\
\text { dissipation. } \\
\text {-It is along the flow path. }\end{array}$ & & & \\
\hline $\begin{array}{l}\text { C. Ensure that TCE } \\
\text { plume is not migrating } \\
\text { unexpectedly. }\end{array}$ & W-1 & $\begin{array}{l}\text {-It will be a weathered well along the } \\
\text { flow path from the TCE impact area to } \\
\text { SP- } 6301 \text {. } \\
\text {-It will be installed in support of this } \\
\text { monitoring program. }\end{array}$ & $\begin{array}{l}\text {-Sample quarterly for } \\
2 \text { years after initiation of the } \\
\text { long-term monitoring, as } \\
\text { described in the RD/RA } \\
\text { Work Plan, to build data set. } \\
\text {-Sample annually } \\
\text { thereafter. } \\
\text { - Reevaluate/optimize as } \\
\text { part of 5-year reviews. }\end{array}$ & $\begin{array}{l}\text { a. When a concentration } \\
\text { of } 3 \mu \mathrm{g} / \mathrm{L} \text { or greater is } \\
\text { detected and confirmed at } \\
\text { Well W- } 1 \text {. }\end{array}$ & $\begin{array}{l}\text { a. Increase sampling frequency to } \\
\text { quarterly at all TCE MNA } \\
\text { locations. After } 4 \text { quarters: (1) If } \\
\text { concentrations return to }<3 \mu \mathrm{g} / \mathrm{L} \text {, } \\
\text { then return to previous sampling } \\
\text { frequency. (2) If concentrations } \\
\text { remain }>3 \mu \mathrm{g} / \mathrm{L} \text { but }<75 \mu \mathrm{g} / \mathrm{L} \text { and } \\
\text { all "B" locations are below } \\
\text { baseline levels and the remainder } \\
\text { of the "C" locations are }<3 \mu \mathrm{g} / \mathrm{L} \text {, } \\
\text { then continue quarterly sampling } \\
\text { at W-1. (3) If concentrations } \\
\text { remain }>3 \mu \mathrm{g} / \mathrm{L} \text { but }<75 \mu \mathrm{g} / \mathrm{L} \text { and } \\
\text { any other "B" location } \\
\text { concentration is above baseline } \\
\text { levels or any other "C" location is } \\
>3 \mu \mathrm{g} / \mathrm{L} \text {, then continue quarterly } \\
\text { sampling at all locations, add } \\
\text { appropriate existing downgradient } \\
\text { monitoring locations to quarterly } \\
\text { sampling, recalculate MNA time } \\
\text { frames, and reevaluate ICs. }\end{array}$ \\
\hline
\end{tabular}


TABLE 5.1 (Cont.)

\begin{tabular}{|c|c|c|c|c|c|}
\hline Objective & $\begin{array}{l}\text { Monitoring } \\
\text { Wella }^{\mathrm{a}}\end{array}$ & Rationale for Selection & Sampling Frequency & $\begin{array}{c}\text { Trigger Concentration } \\
\text { or Event } \\
\end{array}$ & Contingency Action \\
\hline \multirow[t]{5}{*}{ C (Cont.) } & $\begin{array}{l}\text { W-1 } \\
\text { (Cont.) }\end{array}$ & & & $\begin{array}{l}\text { b. When a concentration } \\
\text { of } 75 \mu \mathrm{g} / \mathrm{L} \text { or greater is } \\
\text { detected and confirmed at } \\
\text { Well W-1. }\end{array}$ & $\begin{array}{l}\text { b. If } 2 \text { consecutive quarters with } \\
\text { confirmatory sampling show } \\
\text { concentrations of } 75 \mu \mathrm{g} / \mathrm{L} \text { or } \\
\text { greater, then invoke ICO hot spot } \\
\text { or better remedial alternative. Do } \\
\text { not invoke this contingency } \\
\text { remedy if TCE concentrations in } \\
\text { the center of the plume have } \\
\text { dissipated to }<300 \mu \mathrm{g} / \mathrm{L} \text {. }\end{array}$ \\
\hline & MWS-1 & $\begin{array}{l}\text {-It is a weathered well along the flow } \\
\text { path from the TCE impact area to } \\
\text { SP-6301. } \\
\text {-Recent sampling ( } 1 \text { event) indicates no } \\
\text { detections. }\end{array}$ & $\begin{array}{l}\text {-Sample semiannually for } \\
2 \text { years after initiation of the } \\
\text { long-term monitoring, as } \\
\text { described in the RD/RA } \\
\text { Work Plan. } \\
\text {-Sample MWS-1 and }\end{array}$ & $\begin{array}{l}\text { a. When a concentration } \\
\text { of } 3 \mu \mathrm{g} / \mathrm{L} \text { or greater is } \\
\text { detected and confirmed at } \\
\text { any of the four } \\
\text { unweathered "C" wells. }\end{array}$ & $\begin{array}{l}\text { a. Increase sampling frequency to } \\
\text { quarterly at all TCE MNA } \\
\text { locations. After } 4 \text { quarters: (1) If } \\
\text { concentrations return to }<3 \mu \mathrm{g} / \mathrm{L} \text {, } \\
\text { then return to previous sampling } \\
\text { frequency. (2) If concentrations }\end{array}$ \\
\hline & UW-1 & $\begin{array}{l}\text {-It will be an unweathered well for } \\
\text { detecting vertical migration of TCE } \\
\text { from the weathered unit clustered with } \\
\text { MW- } 4037 \text {. }\end{array}$ & $\begin{array}{l}\text { UW-1 quarterly for } 2 \text { years } \\
\text { to build data set. } \\
\text {-Sample all wells annually } \\
\text { thereafter. }\end{array}$ & & $\begin{array}{l}\text { remain above } 3 \mu \mathrm{g} / \mathrm{L} \text { but less than } \\
\text { the trigger concentration and all } \\
\text { "B" locations are below baseline } \\
\text { levels and the remainder of the }\end{array}$ \\
\hline & $\begin{array}{l}\text { MW-3006 } \\
\text { (UW) }\end{array}$ & $\begin{array}{l}\text {-It is an unweathered well under the } \\
\text { edge of the TCE plume. } \\
\text {-It is clustered with MW- } 3003 \text { and } \\
\text { MW-3023, which have had estimated } \\
\text { detections }(<1 \mathrm{mg} / \mathrm{L}) \text { of TCE. } \\
\text {-All data are nondetects. }\end{array}$ & $\begin{array}{l}\text {-Reevaluate/optimize as } \\
\text { part of 5-year reviews. }\end{array}$ & & $\begin{array}{l}\text { "C" locations are }<3 \mu \mathrm{g} / \mathrm{L} \text {, then } \\
\text { continue quarterly sampling at } \\
\text { location that is }>3 \mu \mathrm{g} / \mathrm{L} \text {. ( }(3) \text { If } \\
\text { concentration remains }>3 \mu \mathrm{g} / \mathrm{L} \text { but } \\
\text { less than the trigger concentration } \\
\text { and any other "B" location } \\
\text { concentration is above baseline } \\
\text { levels or any other "C" location is }\end{array}$ \\
\hline & $\begin{array}{l}\text { MW-3026 } \\
\text { (UW) }\end{array}$ & $\begin{array}{l}\text {-It is an unweathered well in a low- } \\
\text { conductivity area within the TCE } \\
\text { plume. } \\
\text {-It is clustered with MW- } 3027 \text {, which } \\
\text { has had estimated detections }(<1 \mu \mathrm{g} / \mathrm{L}) \\
\text { of TCE. }\end{array}$ & & & $\begin{array}{l}>3 \mu \mathrm{g} / \mathrm{L} \text {, then continue quarterly } \\
\text { sampling at all locations, add } \\
\text { appropriate existing downgradient } \\
\text { monitoring locations to quarterly } \\
\text { sampling, recalculate MNA time } \\
\text { frames, and reevaluate ICs. }\end{array}$ \\
\hline
\end{tabular}

-All data are nondetects. 
TABLE 5.1 (Cont.)

\begin{tabular}{|c|c|c|c|c|c|}
\hline Objective & $\begin{array}{l}\text { Monitoring } \\
\text { Well }^{\mathrm{a}}\end{array}$ & Rationale for Selection & Sampling Frequency & $\begin{array}{c}\text { Trigger Concentration } \\
\text { or Event }\end{array}$ & Contingency Action \\
\hline C (Cont.) & $\begin{array}{l}\text { MW-4007 } \\
\text { (UW) }\end{array}$ & $\begin{array}{l}\text {-It is an unweathered well under the } \\
\text { leading edge of the } 5-\mu \mathrm{g} / \mathrm{L} \text { contour in } \\
\text { the weathered unit. } \\
\text {-It is clustered with MW- } 4001 \text {. } \\
\text {-It is located along the flow path. } \\
\text {-All data are nondetects. }\end{array}$ & & $\begin{array}{l}\text { b. When a concentration } \\
\text { of } 20 \mu \mathrm{g} / \mathrm{L} \text { is detected and } \\
\text { confirmed at MWS- } 1 \text { or } \\
10 \mu \mathrm{g} / \mathrm{L} \text { or greater is } \\
\text { detected and confirmed at } \\
\text { any of the four } \\
\text { unweathered "C" wells. }\end{array}$ & $\begin{array}{l}\text { b. If } 2 \text { consecutive quarters with } \\
\text { confirmation sampling show } \\
\text { concentrations above the trigger } \\
\text { concentration at any of the "C" } \\
\text { locations other than Well W-1, } \\
\text { then invoke ICO localized or } \\
\text { better remedial alternative. Do not } \\
\text { invoke this contingency remedy if } \\
\text { TCE concentrations in the center } \\
\text { of the plume have dissipated to } \\
<300 \mu \mathrm{g} / \mathrm{L} \text {. }\end{array}$ \\
\hline
\end{tabular}




\section{TABLE 5.1 (Cont.)}

\begin{tabular}{|c|c|c|c|c|c|}
\hline Objective & $\begin{array}{l}\text { Monitoring } \\
\text { Well }^{\mathrm{a}}\end{array}$ & Rationale for Selection & Sampling Frequency & $\begin{array}{c}\text { Trigger Concentration } \\
\text { or Event }\end{array}$ & Contingency Action \\
\hline \multirow[t]{2}{*}{$\begin{array}{l}\text { D. Ensure that TCE } \\
\text { plume is not migrating } \\
\text { unexpectedly and } \\
\text { demonstrate that TCE } \\
\text { is not present at } \\
\text { locations where human } \\
\text { exposure could occur. }\end{array}$} & $\begin{array}{l}\text { SP-6301 } \\
\text { Burgermeister } \\
\text { Spring } \\
\text { SP-6303 }\end{array}$ & $\begin{array}{l}\text {-It is the primary discharge point for } \\
\text { groundwater originating from the } \\
\text { Chemical Plant. } \\
\text {-All data are nondetects } \\
\text {-It is a point of exposure. } \\
\text {-It is a discharge point for groundwater } \\
\text { originating from the Chemical Plant. } \\
\text {-Has had estimated detections of TCE } \\
(<1 \mu \mathrm{g} / \mathrm{L}) \text {. } \\
\text {-It is a point of exposure. }\end{array}$ & -Sample semiannually. & $\begin{array}{l}\text { a. When a concentration } \\
\text { of } 3 \mu \mathrm{g} / \mathrm{L} \text { or greater is } \\
\text { detected and confirmed at } \\
\text { either of the "D" wells. }\end{array}$ & $\begin{array}{l}\text { a. Increase sampling frequency to } \\
\text { quarterly at all TCE MNA } \\
\text { locations. Investigate possible } \\
\text { external sources of TCE. After } \\
4 \text { quarters: ( } 1 \text { ) If concentrations } \\
\text { return to }<3 \mu \mathrm{g} / \mathrm{L} \text {, then return to } \\
\text { previous sampling frequency. } \\
\text { (2) If concentrations remain } \\
>3 \mu \mathrm{g} / \mathrm{L} \text { but }<5 \mu \mathrm{g} / \mathrm{L} \text { and all "B" } \\
\text { locations are below baseline levels } \\
\text { and the remainder of the "C" } \\
\text { locations are }<3 \mu \mathrm{g} / \mathrm{L}, \text { then } \\
\text { continue quarterly sampling at } \\
\text { location that is }>3 \mu \mathrm{g} / \mathrm{L} \text {. (3) If } \\
\text { concentration remains }>3 \mu \mathrm{g} / \mathrm{L} \text { but } \\
<5 \mu \mathrm{g} / \mathrm{L} \text { and any other "B" } \\
\text { location concentration is above } \\
\text { baseline levels or any other "C" } \\
\text { location is }>3 \mu \mathrm{g} / \mathrm{L} \text {, then continue } \\
\text { quarterly sampling at all locations, } \\
\text { add appropriate existing } \\
\text { downgradient monitoring } \\
\text { locations to quarterly sampling, } \\
\text { recalculate MNA time frames, and } \\
\text { reevaluate ICs. }\end{array}$ \\
\hline & & & & $\begin{array}{l}\text { b. When a concentration } \\
\text { of } 5 \mu \mathrm{g} / \mathrm{L} \text { or greater is } \\
\text { detected and confirmed at } \\
\text { either of the " } \mathrm{D} \text { " wells. }\end{array}$ & $\begin{array}{l}\text { b. If } 2 \text { consecutive quarters with } \\
\text { confirmation sampling show } \\
\text { concentration at any location is } \\
>5 \mu \mathrm{g} / \mathrm{L} \text {, then invoke ICO hot spot } \\
\text { or better remedial alternative. Do } \\
\text { not invoke this contingency } \\
\text { remedy if TCE concentrations in } \\
\text { the center of the plume have } \\
\text { dissipated to }<300 \mu \mathrm{g} / \mathrm{L} \text {. }\end{array}$ \\
\hline
\end{tabular}


TABLE 5.1 (Cont.)

\begin{tabular}{|c|c|c|c|c|c|}
\hline Objective & $\begin{array}{c}\text { Monitoring } \\
\text { Well }^{\mathrm{a}}\end{array}$ & Rationale for Selection & Sampling Frequency & $\begin{array}{c}\text { Trigger Concentration } \\
\text { or Event } \\
\end{array}$ & Contingency Action \\
\hline \multirow[t]{2}{*}{$\begin{array}{l}\text { E. Perform upgradient } \\
\text { monitoring. }\end{array}$} & MW-2035 & $\begin{array}{l}\text {-It is a weathered well at an upgradient } \\
\text { monitoring location. } \\
\text {-All data are nondetects. } \\
\text {-Data set is large. }\end{array}$ & $\begin{array}{l}\text {-Sample semiannually for } \\
2 \text { years after initiation of the } \\
\text { long-term monitoring, as } \\
\text { described in the RD/RA } \\
\text { Work Plan. } \\
\text {-Sample annually } \\
\text { thereafter. } \\
\text {-Reevaluate/optimize as } \\
\text { part of 5-year reviews. }\end{array}$ & $\begin{array}{l}\text { a. When a concentration } \\
\text { of } 3 \mu \mathrm{g} / \mathrm{L} \text { or greater is } \\
\text { detected and confirmed at } \\
\text { MW-2035. }\end{array}$ & $\begin{array}{l}\text { a. Increase sampling frequency to } \\
\text { quarterly at this location and "B" } \\
\text { locations. After } 4 \text { quarters: (1) If } \\
\text { concentrations return to }<3 \mu \mathrm{g} / \mathrm{L} \text {, } \\
\text { then return to previous sampling } \\
\text { frequency. (2) If concentrations } \\
\text { remain }>3 \mu \mathrm{g} / \mathrm{L} \text { but }<10 \mu \mathrm{g} / \mathrm{L} \text { and } \\
\text { all "B" locations are below } \\
\text { baseline levels, then continue } \\
\text { quarterly sampling at location that } \\
\text { is }>3 \mu \mathrm{g} / \mathrm{L} \text {. (3) If concentration } \\
\text { remains }>3 \mu \mathrm{g} / \mathrm{L} \text { but }<10 \mu \mathrm{g} / \mathrm{L} \\
\text { and any other "B" location } \\
\text { concentration is above baseline } \\
\text { levels, then continue quarterly } \\
\text { sampling at all locations, add } \\
\text { appropriate existing downgradient } \\
\text { monitoring locations to quarterly } \\
\text { sampling, investigate possible } \\
\text { upgradient sources or changed } \\
\text { conditions, recalculate MNA time } \\
\text { frames, and reevaluate ICs. }\end{array}$ \\
\hline & & & & $\begin{array}{l}\text { b. When a concentration } \\
\text { of } 10 \mu \mathrm{g} / \mathrm{L} \text { or greater is } \\
\text { detected and confirmed at } \\
\text { MW- } 2035 \text {. }\end{array}$ & $\begin{array}{l}\text { b. If } 2 \text { consecutive quarters with } \\
\text { confirmation sampling show } \\
\text { concentration at any location is } \\
>10 \mu \mathrm{g} / \mathrm{L} \text {, then invoke ICO } \\
\text { localized or better remedial } \\
\text { alternative. Do not invoke this } \\
\text { contingency remedy if TCE } \\
\text { concentrations in the center of the } \\
\text { plume have dissipated to } \\
<300 \mu \mathrm{g} / \mathrm{L} \text {. }\end{array}$ \\
\hline
\end{tabular}




\section{TABLE 5.1 (Cont.)}

\begin{tabular}{|c|c|c|c|c|c|}
\hline Objective & $\begin{array}{l}\text { Monitoring } \\
\text { Well }^{\mathrm{a}}\end{array}$ & Rationale for Selection & Sampling Frequency & $\begin{array}{l}\text { Trigger Concentration } \\
\text { or Event }\end{array}$ & Contingency Action \\
\hline \multirow[t]{8}{*}{$\begin{array}{l}\text { F. Demonstrate } \\
\text { hydrologic stability. }\end{array}$} & MW-2039 & $\begin{array}{l}\text {-It is upgradient from TCE area. } \\
\text {-It is a weathered well. }\end{array}$ & \multirow{8}{*}{$\begin{array}{l}\text {-Take semiannual water } \\
\text { level measurements } \\
\text { throughout monitoring } \\
\text { program. } \\
\text {-Construct water table map } \\
\text { for each semiannual } \\
\text { measurement event. }\end{array}$} & \multirow{3}{*}{$\begin{array}{l}\text { a. When a change in the } \\
\text { groundwater table at any } \\
\text { "F" well indicates } \\
\text { insufficient monitoring } \\
\text { coverage. May be due to } \\
\text { changes in flow directions } \\
\text { or an increase or decrease } \\
\text { in gradient. }\end{array}$} & \multirow{3}{*}{$\begin{array}{l}\text { a. (1) Reevaluate MNA predicted } \\
\text { time frames. (2) Reevaluate ICs. } \\
\text { (3) Reevaluate if additional wells } \\
\text { should be included in monitoring } \\
\text { program because of changes in } \\
\text { groundwater flow. }\end{array}$} \\
\hline & MW-3023 & $\begin{array}{l}\text {-It is cross-gradient from TCE area. } \\
\text {-It is a weathered well. }\end{array}$ & & & \\
\hline & MW-3025 & $\begin{array}{l}\text {-It is cross-gradient from TCE area. } \\
\text {-It is a weathered well. }\end{array}$ & & & \\
\hline & MW-4022 & -It is upgradient from TCE area. & & \multirow{5}{*}{$\begin{array}{l}\text { b. When the groundwater } \\
\text { elevation at any "F" well } \\
\text { has decreased to a level } \\
\text { that results in "dry" } \\
\text { monitoring wells. }\end{array}$} & \multirow{5}{*}{$\begin{array}{l}\text { b. Reevaluate adequacy of } \\
\text { monitoring network for long-term } \\
\text { program. }\end{array}$} \\
\hline & (UW) & & & & \\
\hline & MW-4032 & $\begin{array}{l}\text {-It is within the TCE area. } \\
\text {-It is along the flow path. } \\
\text {-It is a weathered well. }\end{array}$ & & & \\
\hline & MW-4034 & $\begin{array}{l}\text {-It is upgradient from TCE area. } \\
\text {-It is a weathered well. }\end{array}$ & & & \\
\hline & MW-4036 & $\begin{array}{l}\text {-It is downgradient from TCE area. } \\
\text {-It is along the flow path. } \\
\text {-It is a weathered well. }\end{array}$ & & & \\
\hline $\begin{array}{l}\text { G. Monitor rebound } \\
\text { TCE concentrations } \\
\text { after pilot-phase ICO. }\end{array}$ & MW-3034 & $\begin{array}{l}\text {-It was the location exhibiting the } \\
\text { highest TCE contamination that was } \\
\text { impacted by the pilot-phase ICO. TCE } \\
\text { concentrations were } 1,000 \mu \mathrm{g} / \mathrm{L} \text { and } \\
\text { decreased to nondetects. Presently, TCE } \\
\text { concentrations have rebounded to } \\
200 \mu \mathrm{g} / \mathrm{L} \text {. } \\
\text {-It is a good location to evaluate } \\
\text { rebound and quantify changes in the } \\
\text { plume. }\end{array}$ & -Sample semiannually. & None. & None. \\
\hline
\end{tabular}

a Wells UW-1 and W-1 are to be built. All other monitoring wells exist. 
TABLE 5.2 Preliminary Monitored Natural Attenuation Performance Monitoring for Nitrate (to be finalized in the RD/RA Work Plan)

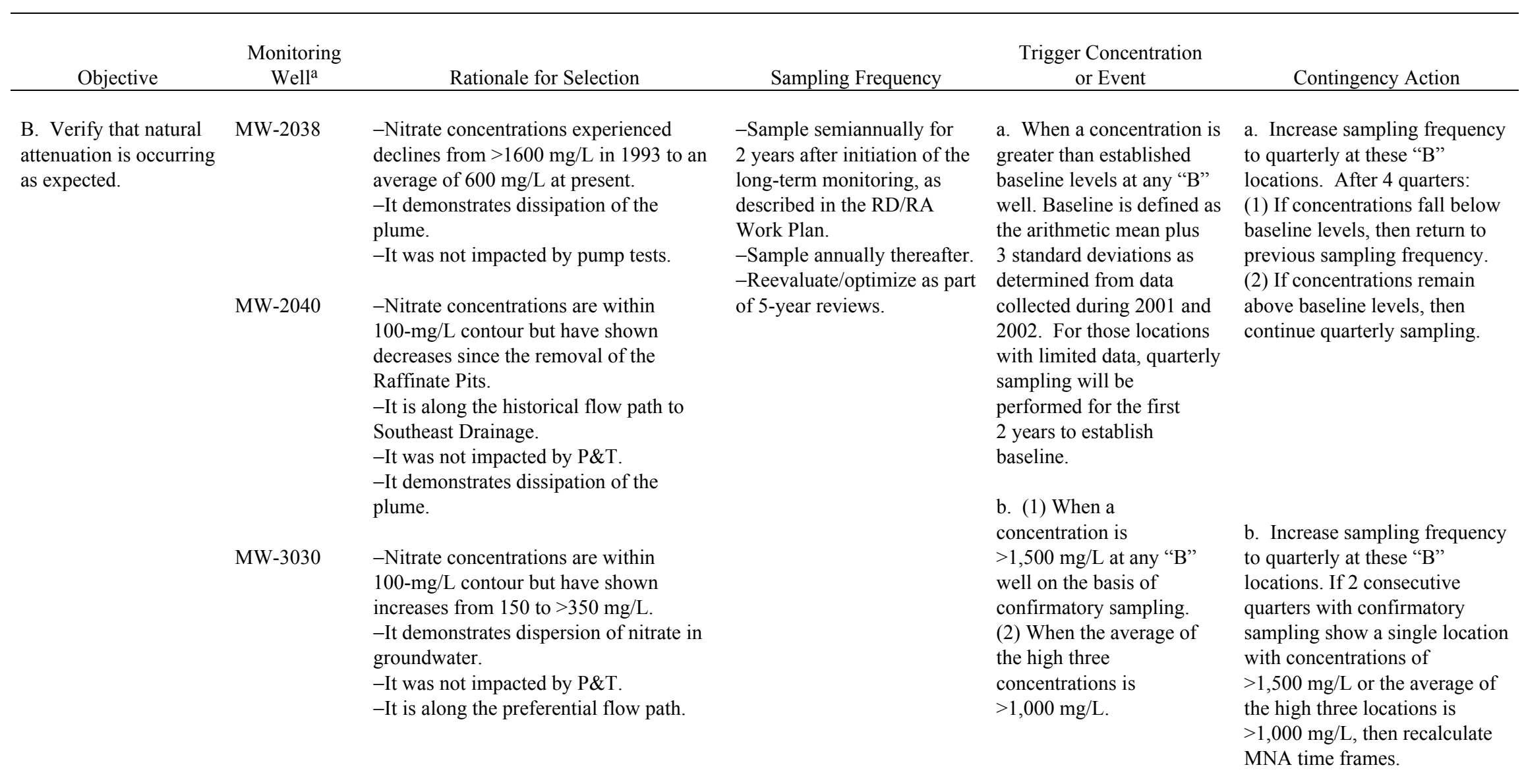


TABLE 5.2 (Cont.)

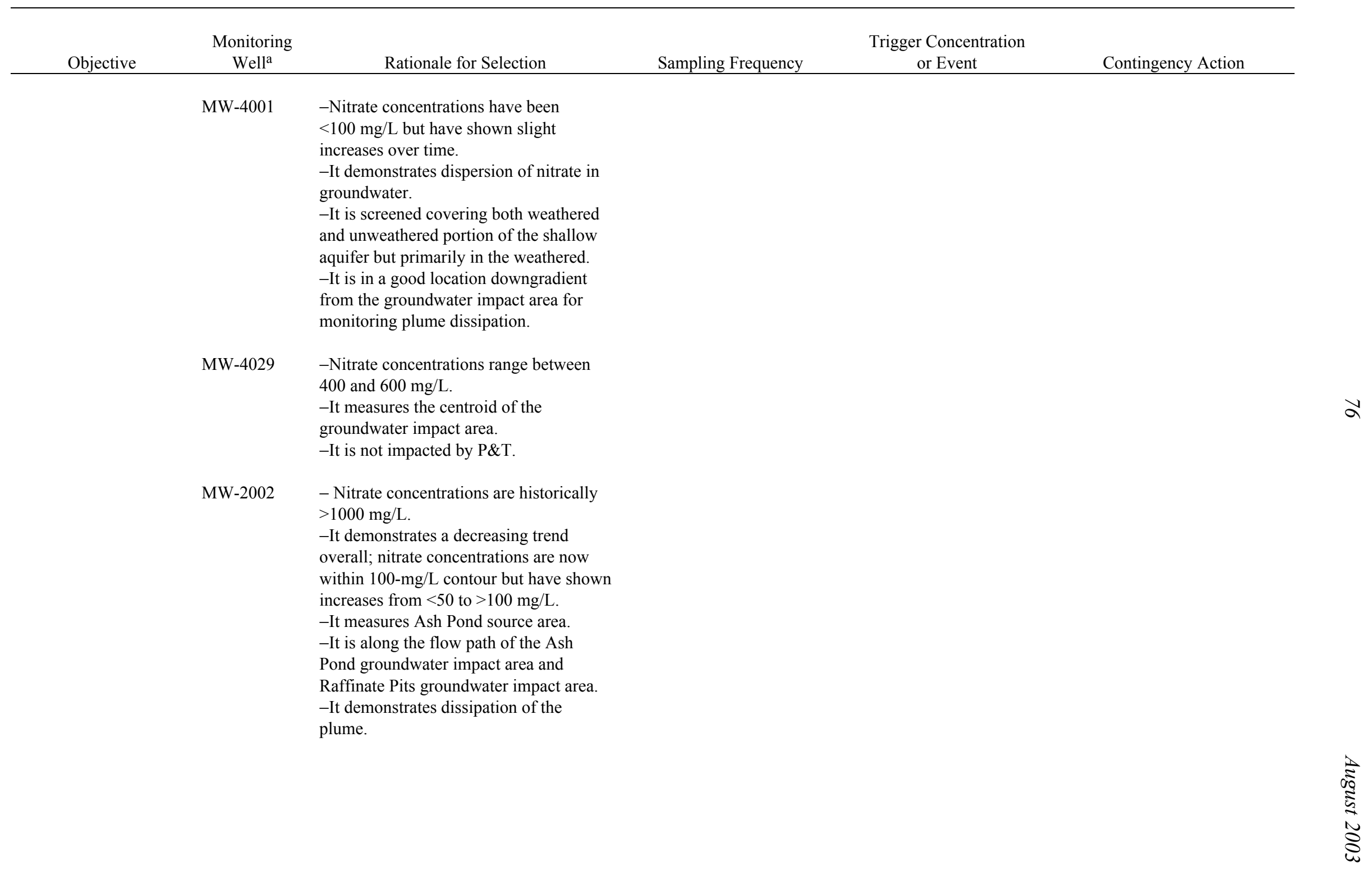


TABLE 5.2 (Cont.)

\begin{tabular}{|c|c|c|c|c|c|}
\hline Objective & $\begin{array}{c}\text { Monitoring } \\
\text { Well }^{\mathrm{a}}\end{array}$ & Rationale for Selection & Sampling Frequency & $\begin{array}{c}\text { Trigger Concentration } \\
\text { or Event }\end{array}$ & Contingency Action \\
\hline & MW-2005 & $\begin{array}{l}\text {-Nitrate concentrations are within } \\
100 \text {-mg/L contour but have shown } \\
\text { increases from }<100 \text { to }>175 \mathrm{mg} / \mathrm{L} \text {. } \\
\text {-It monitors the Ash Pond groundwater } \\
\text { impact area. }\end{array}$ & & & \\
\hline & MW-4011 & $\begin{array}{l}\text {-Nitrate concentrations increased from } \\
<100 \mathrm{mg} / \mathrm{L} \text { in } 1993 \text { to }>200 \mathrm{mg} / \mathrm{L} \text { in } \\
1998 \text { and went back down to } \\
\text { approximately } 100 \mathrm{mg} / \mathrm{L} \text {. } \\
\text {-It was impacted in } 1990 \mathrm{~s} \text { by Ash Pond } \\
\text { and Raffinate Pits remediation. } \\
\text {-It monitors the Ash Pond and Raffinate } \\
\text { Pits groundwater impact areas. } \\
\text {-Is an unweathered well. It is screened in } \\
\text { the upper } 20 \mathrm{ft} \text {. }\end{array}$ & & & \\
\hline & MW-4013 & $\begin{array}{l}\text {-Nitrate concentrations are }<100 \mathrm{mg} / \mathrm{L} \text {. } \\
\text {-It is screened in weathered/ } \\
\text { unweathered but primarily weathered. } \\
\text {-It monitors the northern flow path from } \\
\text { the Ash Pond groundwater impact area. } \\
\text {-It is along the northern preferential flow } \\
\text { path from the site. } \\
\text {-It is a likely location to demonstrate } \\
\text { dispersion of nitrate in groundwater. }\end{array}$ & & & \\
\hline & MW-3026 & $\begin{array}{l}\text {-Nitrate concentrations are between } \\
100 \text { and } 200 \mathrm{mg} / \mathrm{L} \text {. } \\
\text { - It is an unweathered well. It is } \\
\text { screened } 20 \mathrm{ft} \text { below the } \\
\text { weathered/unweathered contact. It has a } \\
\text { screened interval of } 20 \mathrm{ft} \text {. } \\
\text { - It is nested with MW-3027. }\end{array}$ & & & \\
\hline
\end{tabular}


TABLE 5.2 (Cont.)

\begin{tabular}{|c|c|c|c|c|c|}
\hline Objective & $\begin{array}{l}\text { Monitoring } \\
\text { Wella }^{\mathrm{a}}\end{array}$ & Rationale for Selection & Sampling Frequency & $\begin{array}{c}\text { Trigger Concentration } \\
\text { or Event }\end{array}$ & Contingency Action \\
\hline $\begin{array}{l}\text { C. Ensure that nitrate } \\
\text { plume is not migrating } \\
\text { unexpectedly. }\end{array}$ & $\begin{array}{l}\text { MW-3006 } \\
\text { (UW) }\end{array}$ & $\begin{array}{l}\text {-It is a weathered well along the flow } \\
\text { path from the Raffinate Pits and Ash } \\
\text { Pond impact areas to SP-6301. } \\
-1995 \text { remedial investigation (RI) data } \\
\text { revealed nitrate concentrations of about } \\
2 \mathrm{mg} / \mathrm{L} \text {. One data point in } 2002 \text { was } \\
9 \mathrm{mg} / \mathrm{L} \text {. } \\
\text {-It will be a weathered well along the } \\
\text { flow path from the Raffinate Pits impact } \\
\text { area to SP-6301. } \\
\text {-It will be installed in support of this } \\
\text { program. } \\
\text {-It will be an unweathered well for } \\
\text { determining if vertical migration of } \\
\text { nitrate has occurred from the weathered } \\
\text { unit. } \\
\text {-It will be clustered with MW- } 4037 \text {. } \\
\text {-It is an unweathered well. } \\
\text {-Nitrate concentrations are }<1 \text { mg/L. } \\
\text {-It is clustered with MW-3003 and } \\
\text { MW-3023, which have nitrate } \\
\text { concentrations at } 300 \text { mg/L. }\end{array}$ & $\begin{array}{l}\text {-Sample semiannually for } \\
2 \text { years after initiation of the } \\
\text { long-term monitoring, as } \\
\text { described in the RD/RA } \\
\text { Work Plan. } \\
\text {-Sample W-1 and UW-1 } \\
\text { quarterly for } 2 \text { years to build } \\
\text { baseline data set. } \\
\text {-Sample all wells annually } \\
\text { thereafter. } \\
\text {-Reevaluate/optimize as part } \\
\text { of 5-year reviews. }\end{array}$ & $\begin{array}{l}\text { a. When a concentration is } \\
\text { greater than established } \\
\text { baseline levels at any "C" } \\
\text { well. Baseline is defined as } \\
\text { the arithmetic mean plus } \\
3 \text { standard deviations as } \\
\text { determined from data } \\
\text { collected during } 2001 \text { and } \\
2002 \text {. For new wells or } \\
\text { those locations with } \\
\text { limited data, quarterly } \\
\text { sampling will be } \\
\text { performed for the first } \\
2 \text { years to establish } \\
\text { baseline. } \\
\text { b. When a concentration is } \\
>500 \text { mg/L at any "C" well } \\
\text { on the basis of } \\
\text { confirmatory sampling. }\end{array}$ & $\begin{array}{l}\text { a. Increase sampling frequency } \\
\text { to quarterly at all nitrate } \\
\text { locations. After } 4 \text { quarters: } \\
\text { (1) If concentrations fall below } \\
\text { baseline levels, then return to } \\
\text { previous sampling frequency. } \\
\text { (2) If concentrations remain } \\
\text { above baseline levels, then } \\
\text { continue quarterly sampling. } \\
\text { Add appropriate monitoring } \\
\text { locations. }\end{array}$ \\
\hline
\end{tabular}


TABLE 5.2 (Cont.)

\begin{tabular}{|c|c|c|c|c|c|}
\hline Objective & $\begin{array}{l}\text { Monitoring } \\
\text { Wella }^{\mathrm{a}}\end{array}$ & Rationale for Selection & Sampling Frequency & $\begin{array}{c}\text { Trigger Concentration } \\
\text { or Event }\end{array}$ & Contingency Action \\
\hline $\begin{array}{l}\text { D. Ensure that nitrate } \\
\text { plume is not migrating } \\
\text { unexpectedly and } \\
\text { demonstrate that nitrate } \\
\text { is not present at } \\
\text { concentrations that are } \\
\text { not protective of the } \\
\text { recreational visitor } \\
\text { scenario. }\end{array}$ & SP-6301 & $\begin{array}{l}\text {-It is the primary discharge point for } \\
\text { groundwater originating from the } \\
\text { chemical plant. } \\
\text {-Nitrate concentrations decreased } \\
\text { substantially after Ash Pond Diversion } \\
\text { was constructed. Levels have since } \\
\text { stabilized to }<20 \mathrm{mg} / \mathrm{L} \text {. } \\
\text {-It is a point of exposure. } \\
\text {-It is a discharge point for groundwater } \\
\text { originating from the Chemical Plant. } \\
\text {-Nitrate concentrations declined from a } \\
\text { high of } 66 \mathrm{mg} / \mathrm{L} \text { to }<20 \mathrm{mg} / \mathrm{L} \text {. } \\
\text {-It is a point of exposure. }\end{array}$ & -Sample semiannually. & $\begin{array}{l}\text { a. When a concentration is } \\
\text { greater than established } \\
\text { baseline levels at either } \\
\text { " } \mathrm{D} \text { " well. Baseline is } \\
\text { defined as the arithmetic } \\
\text { mean plus } 3 \text { standard } \\
\text { deviations as determined } \\
\text { from data collected during } \\
2001 \text { and } 2002 \text {. }\end{array}$ & $\begin{array}{l}\text { a. Increase sampling frequency } \\
\text { to quarterly at all nitrate MNA } \\
\text { locations. Investigate possible } \\
\text { external sources of nitrate. } \\
\text { After } 4 \text { quarters, continue } \\
\text { quarterly monitoring at all } \\
\text { locations that exceed baseline } \\
\text { levels, and return to semiannual } \\
\text { sampling for locations that are } \\
\text { below baseline. Add } \\
\text { appropriate monitoring } \\
\text { locations. } \\
\text { b. Increase sampling frequency } \\
\text { to quarterly at all nitrate } \\
\text { locations. If } 2 \text { consecutive } \\
\text { quarters with confirmatory } \\
\text { sampling show concentrations } \\
\text { of }>100 \text { mg/L, then recalculate } \\
\text { MNA time frames and } \\
\text { reevaluate ICs. }\end{array}$ \\
\hline
\end{tabular}

E. Perform upgradient MW-2035 monitoring.
-It is a weathered well upgradient of the monitoring location.

-All nitrate data are $<1 \mathrm{mg} / \mathrm{L}$

-Data set is large.

-It is the same upgradient location as that used for TCE monitoring approach.
Sample semiannually or 2 years after initiation of the long-term monitoring, as described in the RD/RA Work Plan.

-Sample annually thereafter. -Reevaluate/optimize as part of 5-year reviews. a. When a concentration is greater than established baseline levels at

Well MW-2035. Baseline is defined as the arithmetic mean plus 3 standard

deviations as determined from data collected during 2001 and 2002. a. Increase sampling frequency to quarterly at all nitrate locations. After 4 quarters:

(1) If concentrations fall below baseline levels, then return to previous sampling frequency.

(2) If concentrations remain above baseline levels, then continue quarterly sampling. Add appropriate monitoring locations. 
TABLE 5.2 (Cont.)

\begin{tabular}{|c|c|c|c|c|c|}
\hline Objective & $\begin{array}{l}\text { Monitoring } \\
\text { Well }^{\mathrm{a}}\end{array}$ & Rationale for Selection & Sampling Frequency & $\begin{array}{c}\text { Trigger Concentration } \\
\text { or Event }\end{array}$ & Contingency Action \\
\hline & & & & $\begin{array}{l}\text { b. When a concentration is } \\
>100 \mathrm{mg} / \mathrm{L} \text { at } \mathrm{MW}-0235 \\
\text { on the basis of } 2 \text { quarters } \\
\text { of confirmatory sampling. }\end{array}$ & $\begin{array}{l}\text { b. Increase sampling frequency } \\
\text { to quarterly at all nitrate } \\
\text { locations. If } 2 \text { consecutive } \\
\text { quarters of confirmatory } \\
\text { sampling show concentrations } \\
\text { of }>100 \mathrm{mg} / \mathrm{L} \text {, then recalculate } \\
\text { MNA time frames. }\end{array}$ \\
\hline \multirow[t]{3}{*}{$\begin{array}{l}\text { F. Demonstrate } \\
\text { hydrologic stability. }\end{array}$} & MW-2032 & $\begin{array}{l}\text {-It is cross-gradient from Ash Pond } \\
\text { nitrate impact area. } \\
\text {-It is a weathered well. }\end{array}$ & \multirow{3}{*}{$\begin{array}{l}\text {-Take semiannual water } \\
\text { level measurements } \\
\text { throughout monitoring } \\
\text { program. } \\
\text {-Construct water table map } \\
\text { for each semiannual } \\
\text { measurement event. }\end{array}$} & \multirow{2}{*}{$\begin{array}{l}\text { a. When a change in the } \\
\text { groundwater table indicates } \\
\text { insufficient monitoring } \\
\text { coverage. May be due to } \\
\text { changes in flow directions } \\
\text { or an increase or decrease } \\
\text { in gradient. }\end{array}$} & \multirow{2}{*}{$\begin{array}{l}\text { a. (1) Reevaluate MNA } \\
\text { predicted time frames. } \\
\text { (2) Reevaluate ICs. } \\
\text { (3) Reevaluate if additional } \\
\text { wells should be included in } \\
\text { monitoring program because or } \\
\text { changes in groundwater flow. }\end{array}$} \\
\hline & MW-4023 & $\begin{array}{l}\text {-It is upgradient from the Raffinate Pits } \\
\text { nitrate impact area. } \\
\text {-It is a weathered well. }\end{array}$ & & & \\
\hline & $\begin{array}{l}\text { MW-4022 } \\
\text { (UW) }\end{array}$ & $\begin{array}{l}\text {-It is upgradient from the nitrate area. } \\
\text {-It is an unweathered well. }\end{array}$ & & $\begin{array}{l}\text { b. When the groundwater } \\
\text { elevation has decreased to } \\
\text { a level that results in "dry" } \\
\text { monitoring wells. }\end{array}$ & $\begin{array}{l}\text { b. Reevaluate adequacy of } \\
\text { monitoring network for long- } \\
\text { term program. }\end{array}$ \\
\hline
\end{tabular}

a Wells UW-1 and W-1 are to be constructed. All other monitoring wells exist. 
TABLE 5.3 Preliminary Monitored Natural Attenuation Performance Monitoring for Uranium (to be finalized in the RD/RA Work Plan)

\begin{tabular}{|c|c|c|c|c|c|}
\hline Objective & $\begin{array}{l}\text { Monitoring } \\
\text { Well }^{\mathrm{a}}\end{array}$ & Rationale for Selection & Sampling Frequency & $\begin{array}{c}\text { Trigger Concentration } \\
\text { or Event } \\
\end{array}$ & Contingency Action \\
\hline $\begin{array}{l}\text { B. Verify that } \\
\text { natural attenuation is } \\
\text { occurring as } \\
\text { expected. }\end{array}$ & MW-3024 & $\begin{array}{l}\text {-It is the first of two wells with } \\
\text { uranium concentrations above the } \\
\text { MCL. Stable concentrations have } \\
\text { ranged from } 44 \text { to } 72 \mathrm{pCi} / \mathrm{L} \text { over last } \\
6 \text { years. } \\
\text {-It was not impacted by P\&T. } \\
\text {-It is the second of two wells with } \\
\text { uranium concentrations above the } \\
\text { MCL. Stable concentrations have } \\
\text { ranged from } 47 \text { to } 73 \text { pCi/L over last } \\
2 \text { years. } \\
\text {-It is along the flow path from MW- } \\
3024 \text {. } \\
\text {-It was not impacted by P\&T. }\end{array}$ & $\begin{array}{l}\text {-Sample semiannually for } \\
2 \text { years after initiation of the } \\
\text { long-term monitoring, as } \\
\text { described in the RD/RA } \\
\text { Work Plan. } \\
\text {-Sample annually thereafter. } \\
\text {-Reevaluate/optimize as part } \\
\text { of 5-year reviews. }\end{array}$ & $\begin{array}{l}\text { a. When a concentration is } \\
\text { greater than established } \\
\text { baseline levels at any "B" } \\
\text { well. Baseline is defined as } \\
\text { the arithmetic mean plus } \\
3 \text { standard deviations as } \\
\text { determined from data } \\
\text { collected during } 2001 \text { and } \\
2002 \text {. } \\
\text { b. When a concentration is } \\
>300 \text { pCi/L at any "B" } \\
\text { well on the basis of } \\
\text { confirmatory sampling. }\end{array}$ & $\begin{array}{l}\text { a. Increase sampling frequency to } \\
\text { quarterly at these "B" locations. } \\
\text { After } 4 \text { quarters: (1) If } \\
\text { concentrations fall below baseline } \\
\text { levels, then return to previous } \\
\text { sampling frequency. (2) If } \\
\text { concentrations remain above } \\
\text { baseline levels, then continue } \\
\text { quarterly sampling. } \\
\text { b. Increase sampling frequency to } \\
\text { quarterly at these "B" locations. If } \\
2 \text { consecutive quarters with } \\
\text { confirmatory sampling show a } \\
\text { single location with concentrations } \\
\text { of }>300 \text { pCi/L, then recalculate } \\
\text { MNA time frames. }\end{array}$ \\
\hline
\end{tabular}

C. Ensure that MWS-1

uranium plume is not

migrating

unexpectedly.
-It is along the flow path for nitrate and -Sample quarterly for TCE contaminants. It should also be along the uranium flow path.

-It has three data points; highest is $1.3 \mathrm{pCi} / \mathrm{L}$.

MW-4036

-It is a weathered well along the flow path from impacted wells. -One 2001 data point is $15 \mathrm{pCi} / \mathrm{L}$.
-It will be a weathered well along the flow path for nitrate and TCE

contaminants. It should also be along the uranium flow path.

\section{2 years after initiation of the}

long-term monitoring, as

described in the RD/RA

Work Plan, to build baseline data set.

-Sample annually thereafter. -Reevaluate/optimize as part of 5-year reviews.

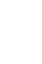

a. When a concentration is greater than established baseline levels at any " $\mathrm{C}$ " well. Baseline is defined as the arithmetic mean plus 3 standard deviations as determined from data

collected during baseline period of 2 years after initiation of the long-term monitoring as described in the RD/RA Work Plan.

(For locations consistently $<5 \mathrm{pCi} / \mathrm{L}$, the threshold of mean plus 3 sigma will be replaced by $20 \mathrm{pCi} / \mathrm{L}$.) a. Increase sampling frequency to quarterly at all uranium locations. After 4 quarters: (1) If concentrations fall below baseline levels, then return to previous sampling frequency. (2) If concentrations remain above baseline levels, then continue quarterly sampling. Add appropriate monitoring locations. 
TABLE 5.3 (Cont.)

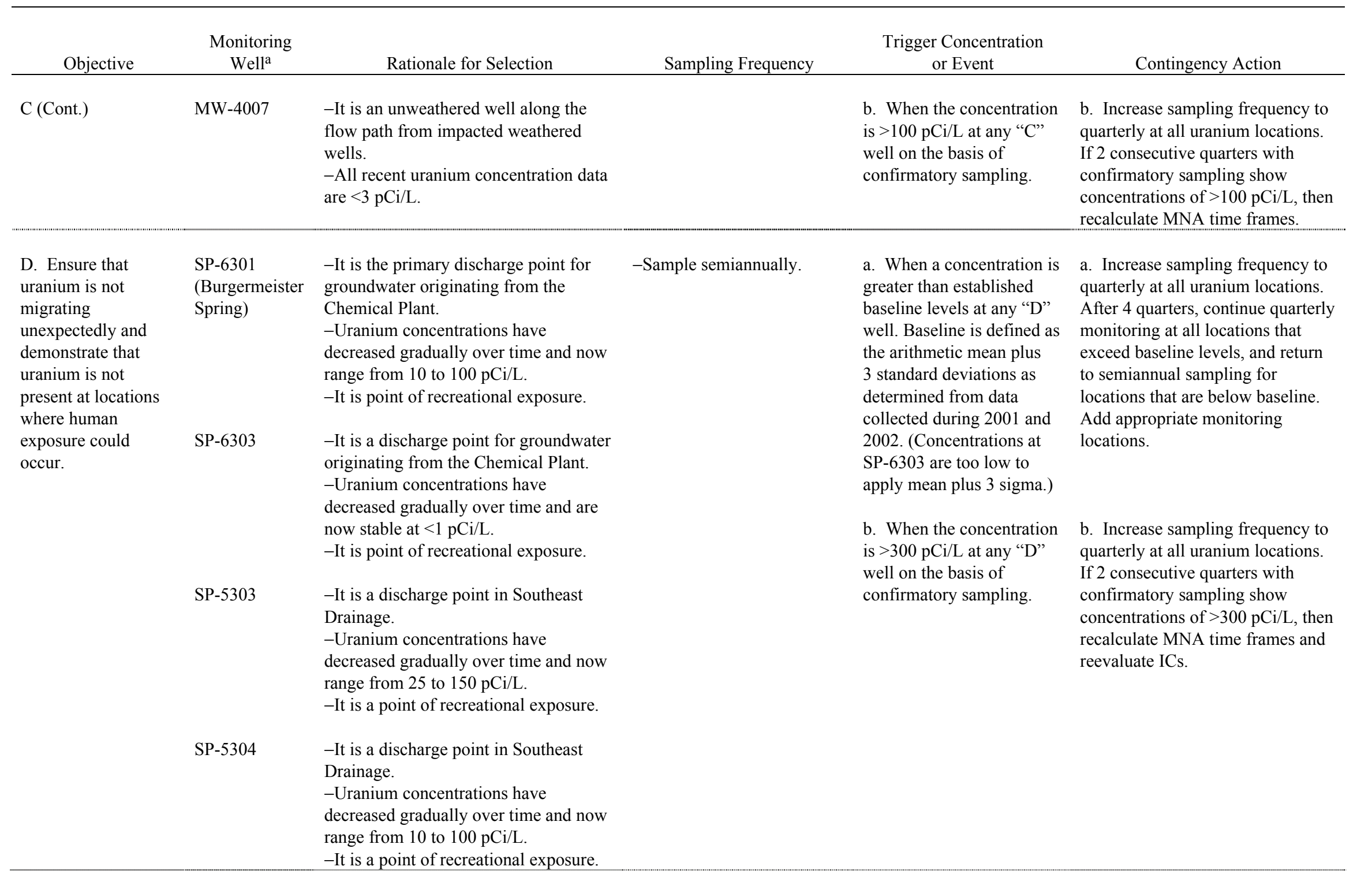


TABLE 5.3 (Cont.)

\begin{tabular}{|c|c|c|c|c|c|}
\hline Objective & $\begin{array}{l}\text { Monitoring } \\
\text { Wella }^{\mathrm{a}}\end{array}$ & Rationale for Selection & Sampling Frequency & $\begin{array}{c}\text { Trigger Concentration } \\
\text { or Event }\end{array}$ & Contingency Action \\
\hline \multirow[t]{2}{*}{$\begin{array}{l}\text { E. Perform } \\
\text { upgradient } \\
\text { monitoring. }\end{array}$} & MW-2035 & $\begin{array}{l}\text {-It is a weathered well upgradient from } \\
\text { the monitoring location. } \\
\text {-Uranium concentrations for the last } \\
5 \text { years have been }<1 \mathrm{pCi} / \mathrm{L} \text {. } \\
\text {-Data set is large. } \\
\text {-It is at the same upgradient location as } \\
\text { that used for other contaminants in } \\
\text { MNA approach. }\end{array}$ & $\begin{array}{l}\text {-Sample semiannually for } \\
2 \text { years after initiation of the } \\
\text { long-term monitoring, as } \\
\text { described in the RD/RA } \\
\text { Work Plan. } \\
\text {-Sample annually thereafter. } \\
\text {-Reevaluate/optimize as part } \\
\text { of 5-year reviews. }\end{array}$ & $\begin{array}{l}\text { a. When a concentration is } \\
>20 \mathrm{pCi} / \mathrm{L} \text { at } \\
\text { Well MW- } 2035 \text {. }\end{array}$ & $\begin{array}{l}\text { a. Increase sampling frequency to } \\
\text { quarterly at all uranium locations. } \\
\text { After } 4 \text { quarters: (1) If } \\
\text { concentrations fall below baseline } \\
\text { levels, then return to previous } \\
\text { sampling frequency. (2) If } \\
\text { concentrations remain above } \\
\text { baseline levels, then continue } \\
\text { quarterly sampling. Add } \\
\text { appropriate monitoring locations. }\end{array}$ \\
\hline & & & & $\begin{array}{l}\mathrm{b} \text {. When concentration is } \\
>100 \mathrm{pCi} / \mathrm{L} \text { at } \\
\text { Well MW- } 2035 \text { on the } \\
\text { basis of } 2 \text { quarters of } \\
\text { confirmatory sampling. }\end{array}$ & $\begin{array}{l}\text { b. Increase sampling frequency to } \\
\text { quarterly at all uranium locations. } \\
\text { If } 2 \text { consecutive quarters with } \\
\text { confirmatory sampling show } \\
\text { concentrations of }>100 \mathrm{pCi} / \mathrm{L} \text {, then } \\
\text { recalculate MNA time frames. }\end{array}$ \\
\hline $\begin{array}{l}\text { F. Demonstrate } \\
\text { hydrologic stability. }\end{array}$ & $\begin{array}{l}\text { Locations } \\
\text { established as } \\
\text { part of TCE } \\
\text { and nitrate } \\
\text { evaluations are } \\
\text { sufficient for } \\
\text { uranium. }\end{array}$ & & $\begin{array}{l}\text {-Take semiannual water } \\
\text { level measurements } \\
\text { throughout monitoring } \\
\text { program. } \\
\text {-Construct water table map } \\
\text { for each semi-annual } \\
\text { measurement event. }\end{array}$ & $\begin{array}{l}\text { a. When a change in the } \\
\text { groundwater table indicates } \\
\text { insufficient monitoring } \\
\text { coverage. May be due to } \\
\text { changes in flow directions } \\
\text { or an increase or decrease } \\
\text { in gradient. }\end{array}$ & $\begin{array}{l}\text { a. (1) Reevaluate MNA predicted } \\
\text { time frames. (2) Reevaluate ICs. } \\
\text { (3) Reevaluate if additional wells } \\
\text { should be included in monitoring } \\
\text { program because of changes in } \\
\text { groundwater flow. }\end{array}$ \\
\hline & & & & $\begin{array}{l}\text { b. When the groundwater } \\
\text { elevation has decreased to } \\
\text { a level that results in "dry" } \\
\text { monitoring wells. }\end{array}$ & $\begin{array}{l}\text { b. Reevaluate adequacy of } \\
\text { monitoring network for long-term } \\
\text { program. }\end{array}$ \\
\hline
\end{tabular}

a Well W-1 is to be constructed. All other monitoring wells exist. 
TABLE 5.4 Preliminary Monitored Natural Attenuation Performance Monitoring for Nitroaromatic Compounds (to be finalized in the RD/RA Workplan)

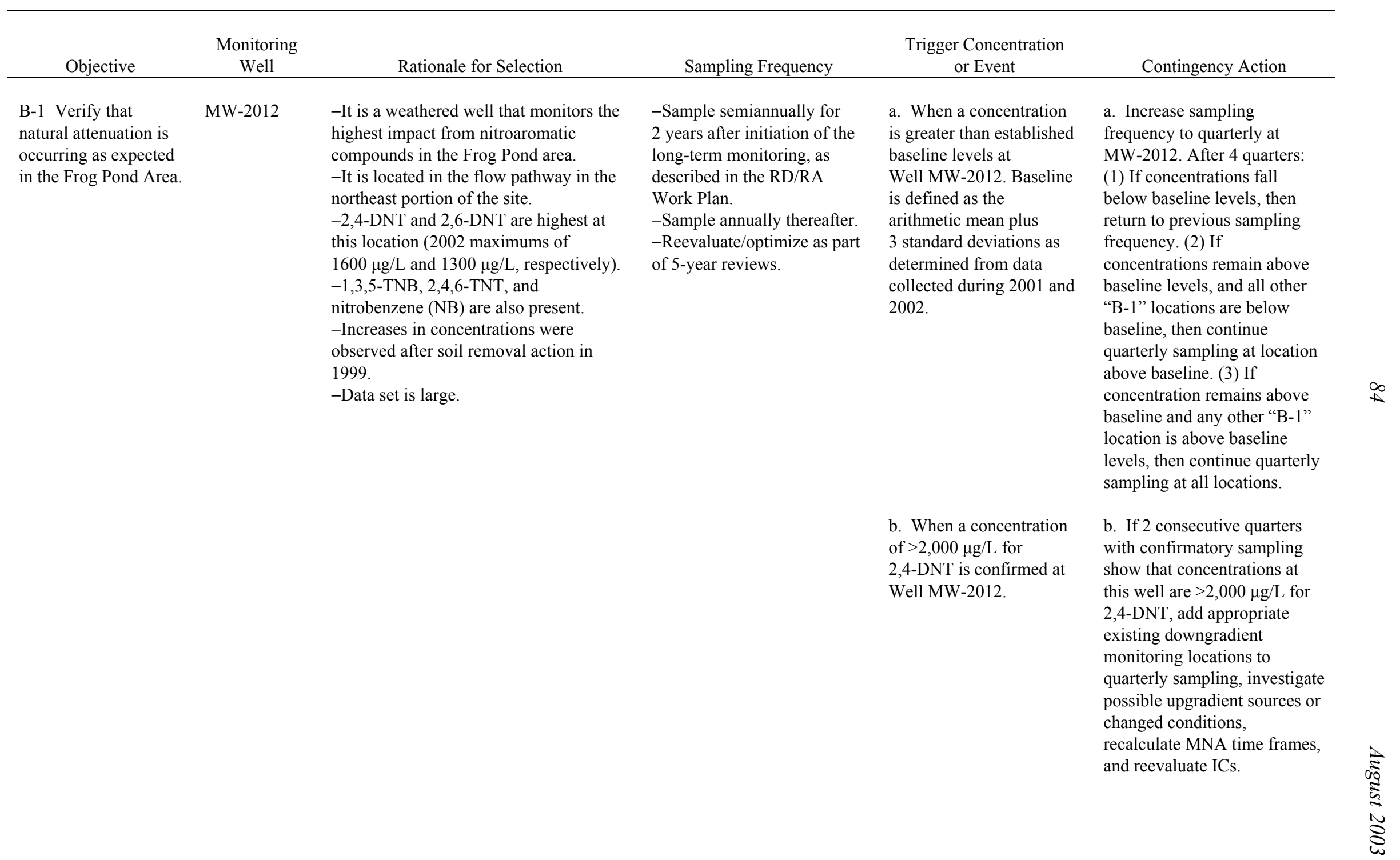


TABLE 5.4 (Cont.)

\begin{tabular}{|c|c|c|c|c|c|}
\hline Objective & $\begin{array}{c}\text { Monitoring } \\
\text { Well }\end{array}$ & Rationale for Selection & Sampling Frequency & $\begin{array}{c}\text { Trigger Concentration } \\
\text { or Event }\end{array}$ & Contingency Action \\
\hline B-1 (Cont.) & MW-2052 & $\begin{array}{l}\text {-It is a weathered well upgradient from the } \\
\text { highest impact from nitroaromatic } \\
\text { compounds in the Frog Pond area. } \\
\text {-It can be used to demonstrate a decrease } \\
\text { of contaminants. } \\
-2,4-\mathrm{DNT} \text { is present at } 0.15 \mu \mathrm{g} / \mathrm{L} \text {. } \\
\text {-1,3,5-TNB and } 2,6 \text {-DNT are also present. } \\
\text {-Data set is large. } \\
\text {-It is a weathered well downgradient from } \\
\text { the highest impact from nitroaromatic } \\
\text { compounds in the Frog Pond area. } \\
\text {-It can be used to monitor the expected } \\
\text { dispersion of contaminants along the flow } \\
\text { path. } \\
-2,4-D N T \text { is present at } 0.13 \mu \mathrm{g} / \mathrm{L} \text {. } \\
-1,3,5-\mathrm{TNB} \text { and } 2,4,6-\mathrm{TNT} \text { are also } \\
\text { present. } \\
\text {-It was recently installed ( } 2001 \text { ). } \\
\text {-It is a weathered well upgradient from the } \\
\text { highest impact from nitroaromatic } \\
\text { compounds in the Frog Pond area. } \\
\text {-It can be used to demonstrate a decrease } \\
\text { of contaminants. } \\
-2,4-\mathrm{DNT} \text { is present at } 7 \mu \mathrm{g} / \mathrm{L} \text {. } \\
-1,3,5-\mathrm{TNB} \text { and } 2,6-\mathrm{DNT} \text { are also present. } \\
- \text { It was recently installed ( } 2001 \text { ). }\end{array}$ & $\begin{array}{l}\text {-Sample semiannually for } \\
2 \text { years after initiation of the } \\
\text { long-term monitoring, as } \\
\text { described in the RD/RA Work } \\
\text { Plan. } \\
\text {-Sample annually thereafter. } \\
\text {-Reevaluate/optimize as part } \\
\text { of 5-year reviews. }\end{array}$ & $\begin{array}{l}\text { a. When a concentration is } \\
\text { greater than established } \\
\text { baseline levels at any } \\
\text { "B-1" well except } \\
\text { MW-2012. Baseline is } \\
\text { defined as the arithmetic } \\
\text { mean plus } 3 \text { standard } \\
\text { deviations as determined } \\
\text { from data collected during } \\
2001 \text { and } 2002 \text {. }\end{array}$ & $\begin{array}{l}\text { a. Increase sampling frequency } \\
\text { to quarterly at the suspect } \\
\text { "B-1" location. After } \\
4 \text { quarters: (1) If concentrations } \\
\text { fall below baseline levels, then } \\
\text { return to previous sampling } \\
\text { frequency. (2) If } \\
\text { concentrations remain above } \\
\text { baseline levels, and all other } \\
\text { "B-1" locations are below } \\
\text { baseline, then continue } \\
\text { quarterly sampling at location } \\
\text { above baseline. (3) If } \\
\text { concentrations remain above } \\
\text { baseline and any other "B-1" } \\
\text { location is above baseline } \\
\text { levels, then continue quarterly } \\
\text { sampling at all locations } \\
\text { b. If confirmatory sampling } \\
\text { shows the average } \\
\text { concentration of the "B-1" } \\
\text { wells (except MW-2012) is } \\
>400 \mu \text { g/L for } 2,4-D N T \text {, add } \\
\text { appropriate existing } \\
\text { downgradient monitoring } \\
\text { locations to quarterly sampling, } \\
\text { investigate possible upgradient } \\
\text { sources or changed conditions, } \\
\text { recalculate MNA time frames, } \\
\text { and reevaluate ICs. }\end{array}$ \\
\hline
\end{tabular}


TABLE 5.4 (Cont.)

\begin{tabular}{|c|c|c|c|c|c|}
\hline Objective & $\begin{array}{c}\text { Monitoring } \\
\text { Well }\end{array}$ & Rationale for Selection & Sampling Frequency & $\begin{array}{c}\text { Trigger Concentration } \\
\text { or Event }\end{array}$ & Contingency Action \\
\hline \multirow[t]{2}{*}{ B-1 (Cont.) } & MW-4015 & $\begin{array}{l}\text {-It is a weathered well downgradient from } \\
\text { the highest impact from nitroaromatic } \\
\text { compounds in the Frog Pond Area. } \\
\text {-It can be used to monitor expected } \\
\text { dispersion of contaminants along the flow } \\
\text { path. } \\
-2,4-\mathrm{DNT} \text { is present at }<0.11 \mu \mathrm{g} / \mathrm{L} \text {. } \\
-1,3,5-\mathrm{TNB} \text { and } 2,6-\mathrm{DNT} \text { are also present. } \\
\text {-Data set is large. }\end{array}$ & & & \\
\hline & MW-4030 & $\begin{array}{l}\text {-It is a weathered well cross-gradient from } \\
\text { the highest impact from nitroaromatic } \\
\text { compounds in the Frog Pond area. } \\
\text {-It can be used to demonstrate a decrease } \\
\text { of contaminants. } \\
-2,4-\mathrm{DNT} \text { is present at } 0.18 \mu \mathrm{g} / \mathrm{L} \text {. } \\
-1,3,5-\mathrm{TNB}, 2,4,6-\mathrm{TNT} \text {, and } 2,6-\mathrm{DNT} \text { are } \\
\text { also present. } \\
\text {-It was recently installed ( } 2000 \text { ). } \\
\text {-It also monitors Lagoon } 1 \text { at the Weldon } \\
\text { Spring Ordnance Works source area. }\end{array}$ & & & \\
\hline
\end{tabular}


TABLE 5.4 (Cont.)

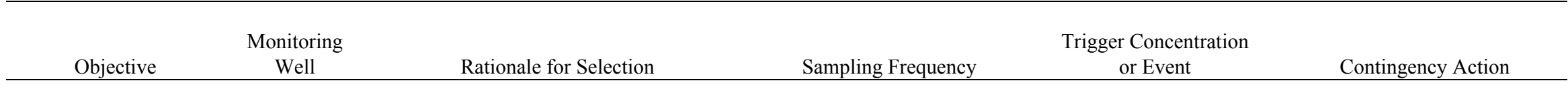

B-2 Verify that natural MW-3030 attenuation is occurring as expected in the

Raffinate Pits and Ash Pond Areas.
-It is a weathered well that monitors the highest impact from nitroaromatic compounds in the Raffinate Pits area.

-It is located in the flow pathway in the southwest portion of the site.

$-2,4-\mathrm{DNT}$ is present at $1.2 \mu \mathrm{g} / \mathrm{L}$.

$-2,6-\mathrm{DNT}$ is also present.

-It was recently installed (2001).

MW-4001-It is a weathered well downgradient from the highest impact from nitroaromatic compounds in the Raffinate Pits area.

-It can be used to monitor expected dispersion of contaminants along the flow path.

$-2,4-\mathrm{DNT}$ is present at $0.22 \mu \mathrm{g} / \mathrm{L}$. $-1,3,5-\mathrm{TNB}, 2,4,6-\mathrm{TNT}$, and 2,6-DNT are also present.

-Data set is large.

-It may also show impact from source areas on the Weldon Spring Ordnance Works.
-Sample semiannually for 2 years after initiation of the long-term monitoring, as described in the RD/RA Work Plan.

-Sample annually thereafter.

-Reevaluate/optimize as part of 5-year reviews.

a. When a concentration is greater than established baseline levels at any "B-2" well. Baseline is defined as the arithmetic mean plus 3 standard deviations as determine from data collected during 2001 and 2002

When the average concentration is $>100 \mu \mathrm{g} / \mathrm{L}$ for 2,4-DNT at any "B-2" well on the basis of confirmatory sampling. a. Increase sampling frequency to quarterly at the suspect "B-2" location. After

4 quarters: (1) If concentrations fall below baseline levels, then return to previous sampling frequency. (2) If concentrations at "B-2" location remain above baseline levels and all other "B-2" locations are below baseline, then continue quarterly sampling at location above baseline. (3) If concentrations remain above baseline and any other "B-2" location is above baseline levels, then continue quarterly sampling at all locations

b. If confirmatory sampling shows the average concentration of the "B-1" wells is $>100 \mu \mathrm{g} / \mathrm{L}$ for 2,4-DNT, add appropriate existing downgradient monitoring locations to quarterly sampling, investigate possible upgradient sources or changed conditions, recalculate MNA time frames, and reevaluate ICs. 
TABLE 5.4 (Cont.)

\begin{tabular}{|c|c|c|c|c|c|}
\hline Objective & $\begin{array}{c}\text { Monitoring } \\
\text { Well }\end{array}$ & Rationale for Selection & Sampling Frequency & $\begin{array}{c}\text { Trigger Concentration } \\
\text { or Event }\end{array}$ & Contingency Action \\
\hline \multirow[t]{3}{*}{ B-2 (Cont.) } & MW-4029 & $\begin{array}{l}\text {-It is a weathered well downgradient from } \\
\text { the highest impact from nitroaromatic } \\
\text { compounds in the Raffinate Pits area. } \\
\text {-It can be used to monitor expected } \\
\text { dispersion of contaminants along the flow } \\
\text { path. } \\
-2,4-D N T \text { is present at } 0.13 \mu \mathrm{g} / \mathrm{L} \text {. } \\
-1,3,5-\mathrm{TNB} \text { and } 2,6 \text {-DNT are also present. } \\
\text {-It was recently installed (2001). }\end{array}$ & & & \\
\hline & MW-2002 & $\begin{array}{l}\text {-It is a weathered well that monitors the } \\
\text { impact from nitroaromatic compounds in } \\
\text { the Ash Pond area. } \\
\text {-It is located in the flow pathway in the } \\
\text { northwest portion of the site. } \\
\text {-No 2,4-DNT is present, but } 1,3,5 \text {-TNB } \\
\text { and } 2,6 \text {-DNT are present. } \\
\text {-Data set is large. }\end{array}$ & & & \\
\hline & MW-3003 & $\begin{array}{l}\text {-It is a weathered well that monitors the } \\
\text { impact from nitroaromatic compounds } \\
\text { north of the Raffinate Pits area. } \\
\text {-It is located in the flow pathway in the } \\
\text { northeastern portion of the site. } \\
-2,4-\mathrm{DNT} \text { is present at } 0.14 \mathrm{mg} / \mathrm{L} \text {. } \\
-2,6 \text {-DNT is also present. } \\
\text {-Data set is large. }\end{array}$ & & & \\
\hline
\end{tabular}


TABLE 5.4 (Cont.)

\begin{tabular}{|c|c|c|c|c|c|}
\hline Objective & $\begin{array}{l}\text { Monitoring } \\
\text { Well }\end{array}$ & Rationale for Selection & Sampling Frequency & $\begin{array}{c}\text { Trigger Concentration } \\
\text { or Event }\end{array}$ & Contingency Action \\
\hline B-2 (Cont.) & MW-4013 & $\begin{array}{l}\text {-It is a weathered well that monitors the } \\
\text { highest impact from nitroaromatic } \\
\text { compounds north of the Chemical Plant } \\
\text { proper. } \\
\text {-It is located in the flow pathway in the } \\
\text { northern portion of the site. } \\
\text {-No 2,4-DNT is present, but 1,3,5-TNB } \\
\text { and 2,6-DNT are present. } \\
\text {-It historically has shown 2,4-DNT } \\
\text { impact. }\end{array}$ & & & \\
\hline $\begin{array}{l}\text { C. Ensure that } \\
\text { 2,4-DNT plume is not } \\
\text { migrating } \\
\text { unexpectedly. }\end{array}$ & MW-4014 & $\begin{array}{l}\text {-It is a weathered well along the flow path } \\
\text { from the Frog Pond area. } \\
\text {-All historical 2,4-DNT data have been } \\
\text { nondetected. } \\
\text {-It historically has shown nitroaromatic } \\
\text { compound impact. }\end{array}$ & $\begin{array}{l}\text {-Sample semiannually for } \\
2 \text { years after initiation of the } \\
\text { long-term monitoring, as } \\
\text { described in the RD/RA Work } \\
\text { Plan. } \\
\text {-Sample all "C" wells } \\
\text { quarterly for } 2 \text { years to } \\
\text { establish data set. } \\
\text {-Sample all "C" wells } \\
\text { annually thereafter. } \\
\text {-Reevaluate/optimize as part } \\
\text { of 5-year reviews. }\end{array}$ & $\begin{array}{l}\text { a. When } 2,4-D N T \text { at any } \\
\text { "C" well exceeds } \\
0.25 \mu \mathrm{g} / \mathrm{L} \text { with } \\
\text { confirmatory sampling. }\end{array}$ & $\begin{array}{l}\text { a. Increase sampling frequency } \\
\text { to quarterly at appropriate } \\
\text { nitroaromatic compound } \\
\text { ("B-1" or "B-2") MNA } \\
\text { location. Investigate possible } \\
\text { external sources of } \\
\text { nitroaromatic compounds. } \\
\text { (1) After } 4 \text { quarters, continue } \\
\text { quarterly monitoring at all } \\
\text { locations that exceed baseline } \\
\text { and return to semiannual } \\
\text { monitoring for locations that } \\
\text { are below baseline. Add } \\
\text { appropriate monitoring } \\
\text { locations. (2) If } 2 \text { consecutive } \\
\text { quarters with confirmatory } \\
\text { sampling show concentrations } \\
\text { greater than } 0.25 \mu \mathrm{g} / \mathrm{L} \text { for } \\
2,4-D N T, \text { then recalculate } \\
\text { MNA time frames and } \\
\text { reevaluate ICs. }\end{array}$ \\
\hline
\end{tabular}


TABLE 5.4 (Cont.)

\begin{tabular}{|c|c|c|c|c|c|}
\hline Objective & $\begin{array}{l}\text { Monitoring } \\
\text { Well }\end{array}$ & Rationale for Selection & Sampling Frequency & $\begin{array}{c}\text { Trigger Concentration } \\
\text { or Event }\end{array}$ & Contingency Action \\
\hline \multirow[t]{4}{*}{ C (Cont.) } & MWS-1 & $\begin{array}{l}\text {-It is a weathered well along the flow path } \\
\text { from the Ash Pond and Raffinate Pits area. } \\
\text {-Recent data indicate no evidence of } \\
\text { 2,4-DNT; however, 2,6-DNT has been } \\
\text { observed. } \\
\text {-Other areas of nitroaromatic compound } \\
\text { impact on the former Weldon Spring } \\
\text { Ordnance Works could affect this location. }\end{array}$ & & & \\
\hline & MW-2021 & $\begin{array}{l}\text {-It is an unweathered well beneath the Ash } \\
\text { Pond area. } \\
\text {-It is clustered with MW-2002, which } \\
\text { shows elevated levels of nitroaromatic } \\
\text { compounds. } \\
\text {-All historical data are nondetects. }\end{array}$ & & & \\
\hline & MW-3006 & $\begin{array}{l}\text {-It is an unweathered well adjacent to the } \\
\text { Raffinate Pits area. } \\
\text {-It is clustered with MW-3003, which } \\
\text { shows elevated levels of nitroaromatic } \\
\text { compounds. } \\
\text {-All data since } 1991 \text { are nondetects. }\end{array}$ & & & \\
\hline & MW-4007 & $\begin{array}{l}\text {-It is an unweathered well downgradient } \\
\text { of the Raffinate Pits area. } \\
\text {-It is clustered with MW- } 4001 \text {, which } \\
\text { shows elevated levels of nitroaromatic } \\
\text { compounds. } \\
\text {-All data since } 1990 \text { are nondetects. }\end{array}$ & & & \\
\hline
\end{tabular}


TABLE 5.4 (Cont.)

\begin{tabular}{|c|c|c|c|c|c|}
\hline Objective & $\begin{array}{l}\text { Monitoring } \\
\text { Well }\end{array}$ & Rationale for Selection & Sampling Frequency & $\begin{array}{c}\text { Trigger Concentration } \\
\text { or Event }\end{array}$ & Contingency Action \\
\hline $\begin{array}{l}\text { D. Ensure that } \\
\text { 2,4-DNT plume is not } \\
\text { migrating } \\
\text { unexpectedly and } \\
\text { demonstrate that } \\
\text { nitroaromatic } \\
\text { compounds are not } \\
\text { present at } \\
\text { concentrations that are } \\
\text { not protective of the } \\
\text { recreational visitor } \\
\text { scenario. }\end{array}$ & $\begin{array}{l}\text { SP-6301 } \\
\text { SP-6303 }\end{array}$ & $\begin{array}{l}\text {-It is the primary discharge point for } \\
\text { groundwater originating from the } \\
\text { Chemical Plant. } \\
\text {-It is a point of recreational exposure. } \\
\text {-2,4-DNT is present at } 0.07 \mu \mathrm{g} / \mathrm{L} \text {. } \\
\text {-2,6-DNT is also present. } \\
\text {-It is a discharge point for groundwater } \\
\text { originating from the Chemical Plant. } \\
\text {-Is point of exposure. } \\
\text {-2,4-DNT is present at } 0.1 \mu \mathrm{g} / \mathrm{L} \text {. } \\
-1,3,5 \text {-TNB, } 2,4,6-\mathrm{TNT} \text {, and } 2,6 \text {-DNT are } \\
\text { also present. }\end{array}$ & -Sample semiannually. & $\begin{array}{l}\text { a. When } 2,4-\mathrm{DNT} \text { exceeds } \\
0.25 \mu \mathrm{g} / \mathrm{L} \text { at either " } \mathrm{D} \text { " } \\
\text { well with confirmatory } \\
\text { sampling. }\end{array}$ & $\begin{array}{l}\text { a. Increase sampling frequency } \\
\text { to quarterly at appropriate } \\
\text { nitroaromatic compound } \\
\text { ("B-1" or "B-2") MNA } \\
\text { location. Investigate possible } \\
\text { external sources of } \\
\text { nitroaromatic compounds. } \\
\text { (1) After } 4 \text { quarters, continue } \\
\text { quarterly monitoring at all } \\
\text { locations that exceed baseline } \\
\text { and return to semiannual } \\
\text { monitoring at locations that are } \\
\text { below baseline. Add } \\
\text { appropriate monitoring } \\
\text { locations. (2) If } 2 \text { consecutive } \\
\text { quarters with confirmatory } \\
\text { sampling show concentrations } \\
\text { of }>0.25 \mu \mathrm{g} / \mathrm{L} \text { for } 2,4-\mathrm{DNT} \text {, } \\
\text { then recalculate MNA time } \\
\text { frames and reevaluate ICs. }\end{array}$ \\
\hline
\end{tabular}


TABLE 5.4 (Cont.)

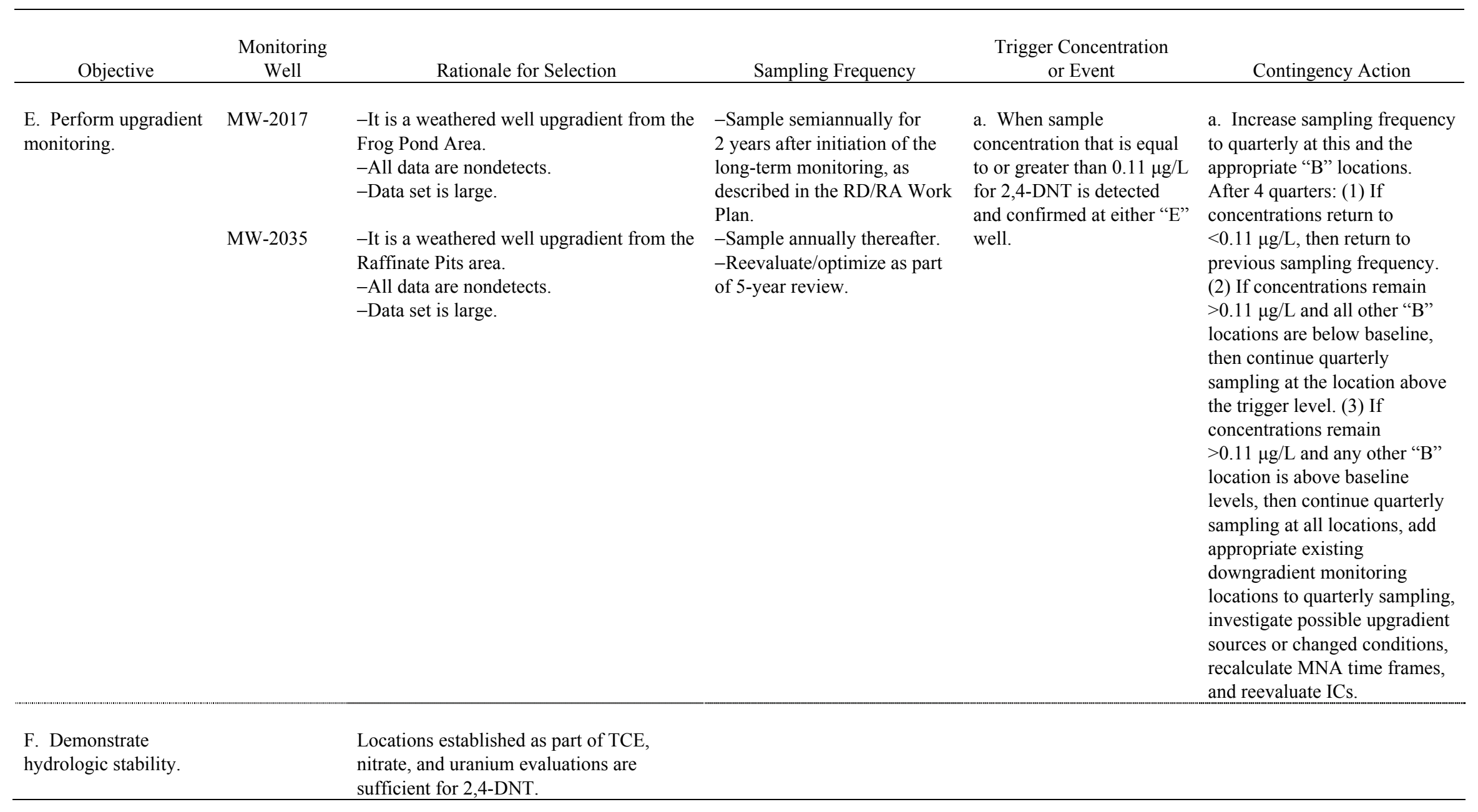




\section{REFERENCES}

ATC Associates, Inc., 2002, Full-Scale Work Plan and Design, In-Situ Chemical Oxidation of TCE in Groundwater Weldon Spring Site Remedial Action Project, St. Louis, MO, July.

Basko, R., 2003, e-mail from Basko (Missouri Department of Health and Senior Services, St. Louis, MO) to R. Cato (Weldon Spring Site Remedial Action Project, St. Charles, MO), May 22.

Brannon, J.M., and J.C. Pennington, 2002, Environmental Fate and Transport Process Descriptors for Explosives, ERCD/EL TR-02-10, prepared for U.S. Army Corps of Engineers, Washington, DC, May.

Cohen, R.M., et al., 1997, Design Guidelines for Conventional Pump-and-Treat Systems, EPA/540/S-97/504, U.S. Environmental Protection Agency, Washington, DC, Sept.

DOE, 1992, Remedial Investigation for the Chemical Plant Area of the Weldon Spring Site, DOE/EIS-0185D (DOE/OR/21548-074, Vol. I), prepared by MK-Ferguson Company and Jacobs Engineering Group, Inc., Weldon Spring, MO, for U.S. Department of Energy, Oak Ridge Field Office, Weldon Spring Site Remedial Action Project, Weldon Spring, MO, Nov.

DOE, 1993, Record of Decision for Remedial Action at the Chemical Plant Area of the Weldon Spring Site, DOE/OR/21548-376, prepared by U.S. Department of Energy, Oak Ridge Field Office, Weldon Spring Site Remedial Action Project, Weldon Spring, MO, Sept.

DOE, 1999a, Supplemental Feasibility Study for Remedial Action for the Groundwater Operable Unit at the Chemical Plant Area of the Weldon Spring Site, Weldon Spring, Missouri, DOE/OR/21548-783, prepared by Argonne National Laboratory, Argonne, IL, for U.S. Department of Energy, Weldon Spring Site Remedial Action Project, Weldon Spring, MO, June.

DOE, 1999b, Proposed Plan for Remedial Action at the Groundwater Operable Unit at the Chemical Plant Area of the Weldon Spring Site, Weldon Spring, Missouri, DOE/OR/21548-733, prepared by Argonne National Laboratory, Argonne, IL, for U.S Department of Energy, Weldon Spring Site Remedial Action Project, Weldon Spring, MO, July.

DOE, 1999c, Decision-Making Framework Guide for the Evaluation and Selection of Monitored Natural Attenuation Remedies at Department of Energy Sites, U.S. Department of Energy, Office of Environmental Restoration, Washington, DC, May 13.

DOE, 2000, Interim Record of Decision for Remedial Action for the Groundwater Operable Unit at the Chemical Plant Area of the Weldon Spring Site, DOE/OR/21548-798, prepared by U.S. Department of Energy, Oak Ridge Operations Office, Oak Ridge, TN, Sept. 
DOE, 2003a, Long-Term Surveillance and Maintenance Plan for the Weldon Spring, Missouri, Site, GJO-2002-342-TAC, Draft, prepared by U.S. Department of Energy, Grand Junction Office, Grand Junction, CO, May.

DOE, 2003b, Proposed Plan for Final Remedial Action for the Groundwater Operable Unit at the Chemical Plant Area of the Weldon Spring Site, Weldon Spring, Missouri, DOE/GJ/79491932, prepared by Argonne National Laboratory, Argonne, IL, for U.S. Department of Energy, Weldon Spring Site Remedial Action Project, Weldon Spring, MO, June.

DOE and DA, 1997a, Baseline Risk Assessment for the Groundwater Operable Units at the Chemical Plant Area and the Ordnance Works Area, Weldon Spring, Missouri, DOE/OR/21548568, prepared by Argonne National Laboratory, Argonne, IL, for U.S. Department of Energy, Weldon Spring Site Remedial Action Project, Weldon Spring, MO, and U.S. Department of the Army, Corps of Engineers, Kansas City District, Kansas City, MO, July.

DOE and DA, 1997b, Remedial Investigation for the Groundwater Operable Units at the Chemical Plant area and the Ordnance Works Area, Weldon Spring Site, Weldon Spring, Missouri, DOE/OR/21548-571, prepared by MK-Ferguson Company and Jacobs Engineering Group, Inc., Weldon Spring, MO, and Argonne National Laboratory, Argonne, IL, for U.S. Department of Energy, Weldon Spring Site Remedial Action Project, Weldon Spring, MO, and U.S. Department of the Army, Corps of Engineers, Kansas City District, Kansas City, MO, July. (see p. 5-10 for TCE and p. D-9 for 2,6-DNT)

DOE and DA, 1998, Feasibility Study for Remedial Action for the Groundwater Operable Units at the Chemical Plant Area and the Ordnance Works Area, Weldon Spring, Missouri, DOE/OR/21548-569, prepared by Argonne National Laboratory, Argonne, IL, for U.S. Department Energy, Weldon Spring Site Remedial Action Project, Weldon Spring, MO, and U.S. Department of the Army, Corps of Engineers, Kansas City District, Kansas City, MO, Dec.

EPA, 1986, Guidelines for Ground-Water Classification under the EPA Ground-Water Protection Strategy, Final Draft, U.S. Environmental Protection Agency, Washington, DC.

EPA, 1990, "National Oil and Hazardous Substances Pollution Contingency Plan; Final Rule (40 CFR Part 300)," Federal Register 55(46):8666-8865, U.S. Environmental Protection Agency, March 8.

EPA, 1999, Use of Monitored Natural Attenuation at Superfund, RCRA Corrective Action, and Underground Storage Tank Sites, OSWER Directive 9200.4-17P, developed by the U.S. Environmental Protection Agency, Office of Solid Waste and Emergency Response, April.

EPA, 2000, Soil Screening Guidance for Radionuclides: User's Guide, EPA/540-R-00-007, U.S. Environmental Protection Agency, Office of Solid Waste and Emergency Response, Washington, DC, Oct.

Freeze, R.A., and J.A. Cherry, 1979, Groundwater, Prentice-Hall, Inc., Englewood Cliffs, NJ. 
Kleeschulte, M.J., 1997, "Second Quarter-1997 Discharge Data for Burgermeister Spring," letter from Kleeschulte (U.S. Geological Survey) to B. Ballew (U.S. Department of Energy), April 17.

Kleeschulte, M.J., and J.L. Imes, 1994, Geohydrology, Water Quality, and Simulation of Groundwater Flow at the Weldon Spring Chemical Plant and Vicinity, St. Charles County, Missouri, 1987-1990, U.S. Geological Survey Open-File Report 93-648, prepared in cooperation with U.S. Department of Energy, Rolla, MO.

MK-Ferguson Company and Jacobs Engineering Group, 1990, Groundwater Classification for the Weldon Spring Site Remedial Action Project, Weldon Spring, Missouri, DOE/OR/21548-116, prepared for U.S. Department of Energy, Oak Ridge Field Office, Weldon Spring Site Remedial Action Project, Weldon Spring, MO, Apr.

MK-Ferguson Company and Jacobs Engineering Group, 1998, Completion Report for the Pilot Pumping Test for the Groundwater Operable Unit at the Weldon Spring Site, DOE/OR/21548757, prepared for U.S. Department of Energy, Oak Ridge Operations Office, Weldon Spring Site Remedial Action Project, St. Charles, MO, Oct.

MK-Ferguson and Jacobs Engineering Group, 2001, Weldon Spring Site Environmental Report for Calendar Year 2000, Rev. 0, DOE/OR/21548-886, prepared for U.S. Department of Energy, Oak Ridge Operations Office, Weldon Spring Site Remedial Action Project, Weldon Spring, MO, July.

MK-Ferguson Company and Jacobs Engineering Group, 2002, Completion Report for the Additional Groundwater Field Studies in Support of the Groundwater Operable Unit, Rev. 0, DOE/OR-21548-920, prepared for U.S. Department of Energy, Oak Ridge Operations Office, Weldon Spring Site Remedial Action Project, St. Charles, MO, July.

Strenge, D.L., and S.R. Peterson, 1989, Chemical Data Bases for the Multimedia Environmental Pollutant Assessment System (MEPAS): Version 1, PNL-7145, Pacific Northwest Laboratory, Richland, WA.

Tomasko, D., 1992, Modeling Vertical and Horizontal Solute Transport for the Weldon Spring Site Remedial Action Project, ANL/EAIS/TM-77, Argonne National Laboratory, Argonne, IL, Nov.

Vogel, J., 2003, e-mail from Vogel (Missouri Department of Conservation, St. Charles, MO) to P. Thompson (U.S. Department of Energy, Weldon Spring Site Remedial Action Project, St. Charles, MO), Apr. 3. 
